\title{
Mountain Meadows Dacite: Oligocene Intrusive Complex That Welds Together the Los Angeles Basin, North western Peninsular Ranges, and Central Transverse Ranges, California
}

Professional Paper 1649

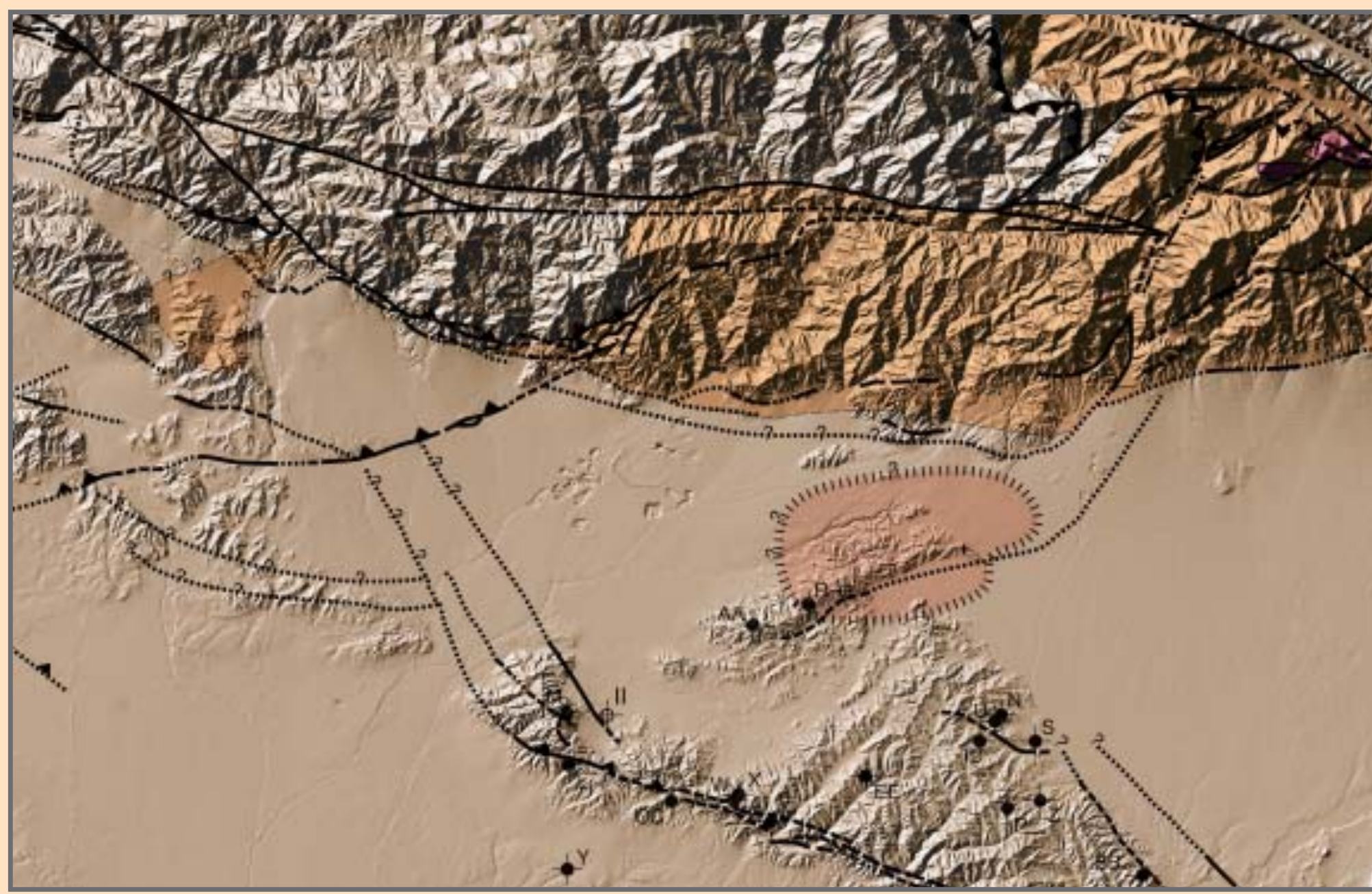

U.S. Department of the Interior U.S. Geological Survey 


\title{
Mountain Meadows Dacite: Oligocene Intrusive Complex That Welds Together the Los Angeles Basin, Northwestern Peninsular Ranges, and Central Transverse Ranges, California
}

\author{
By Thane H. McCulloh, ${ }^{1}$ Larry A. Beyer, ${ }^{2}$ and Ronald W. Morin ${ }^{3}$
}

\begin{abstract}
Dikes and irregular intrusive bodies of distinctive Oligocene biotite dacite and serially related hornblende latite and felsite occur widely in the central and eastern San Gabriel Mountains, southern California, and are related to the Telegraph Peak granodiorite pluton. Identical dacite is locally present beneath Middle Miocene Topanga Group Glendora Volcanics at the northeastern edge of the Los Angeles Basin, where it is termed Mountain Meadows Dacite. This study mapped the western and southwestern limits of the dacite distribution to understand the provenance of derived redeposited clasts, to perceive Neogene offsets on several large strikeslip faults, to test published palinspastic reconstructions, and to better understand the tectonic boundaries that separate contrasting pre-Tertiary rock terranes where the Peninsular Ranges meet the central and western Transverse Ranges and the Los Angeles Basin.

Transported and redeposited clasts of dacite-latite occur in deformed lower Miocene and lower middle Miocene sandy conglomerates (nonmarine, nearshore, and infrequent upper bathyal) close to the northern and northeastern margins of the Los Angeles Basin for a distance of nearly $60 \mathrm{~km}$. Tie-lines between distinctive source suites and clast occurrences indicate that large tracts of the ancestral San Gabriel Mountains were elevated along range-bounding faults as early as 16-15 Ma. The tie-lines prohibit very large strike-slip offsets on those faults. Transport of eroded dacite began south of the range as early as $18 \mathrm{Ma}$.

Published and unpublished data about rocks adjacent to the active Santa Monica-Hollywood-Raymond oblique reverse left-lateral fault indicate that cumulative left slip totals 13-14 km and total offset postdates $7 \mathrm{Ma}$. This cumulative slip, with assembly of stratigraphic and paleogeographic data,
\end{abstract}

${ }^{1} 7136$ Aberdeen Avenue, Dallas, Texas 75230-5407

${ }^{2}$ U.S. Geological Survey, MS 977, 345 Middlefield Road, Menlo Park, California 94025-3591

${ }^{3}$ Morin Biostratigraphic Studies, 2016 Wedgewood Lane, Carrollton, Texas 75006-1722 invalidates prior estimates of 60 to $90 \mathrm{~km}$ of left slip on these faults beginning about 17-16 Ma.

A new and different palinspastic reconstruction of a region southwest of the San Andreas Fault Zone is proposed. Our reconstruction incorporates $20^{\circ}$ of clockwise rotation of tracts north of the Raymond Fault from the easternmost Santa Monica Mountains to the Vasquez Creek Fault (San Gabriel south branch). We interpret the Vasquez Creek Fault as a reverse and right-lateral tear fault. Right slip on the tear becomes reverse dip slip on the northeast-striking ClamshellSawpit fault complex, interpreted as an offset part of the Mount Lukens Fault. This explains the absence of evidence for lateral offset of the Glendora Volcanics and associated younger marine strata where those are broken farther east by the eastern Sierra Madre reverse fault system. About $34 \mathrm{~km}$ of right slip is suggested for all breaks of the San Gabriel fault system.

New paleogeographic maps of the Paleogene basin margin and of a Middle Miocene marine embayment and strandline derive in part from our palinspastic reconstruction. These appealingly simple maps fit well with data from the central Los Angeles Basin to the south and southwest.

\section{Introduction}

The southeastern end of the western Transverse Ranges, the central Transverse Ranges (San Gabriel Mountains), and the northeastern part of the Los Angeles Basin meet the northwestern tip of the Peninsular Ranges within a 4,000-km² rectangular area of southern California (fig. 1). This area is subdivided three-dimensionally by a complex of more or less conspicuous intersecting or interlocking fault zones, many of which are currently active. Some of these zones record repeated movements beginning before $15 \mathrm{Ma}$. The resultant mosaic of fault blocks show complex and partly divergent histories (Powell, 1993, plate I). A petrologically distinctive and petrographically unique intrusive igneous complex of restricted areal extent, the 27.6-Ma Mountain Meadows Dacite (Shelton, 1955; Nourse and others, 1998; this report), straddles several major fault zones and thereby binds together key blocks of the mosaic. The disposition of this complex, 
and of several connected Miocene sedimentary and extrusive formations, imposes strict limits on the range of movement histories for the mosaic. This paper (1) summarizes salient facts about the Mountain Meadows Dacite and some older and younger associated units, (2) relates those facts to histories of particular faults and fault blocks, (3) develops a new palinspastic reconstruction, and (4) considers structural consequences and regional paleogeographic and paleotectonic implications of the findings.

\section{Acknowledgements}

Most of the new work reported here was supported by the U. S. Geological Survey, albeit intermittently and over five decades. F. H. Olmstead introduced the Telegraph Peak granodiorite and its chilled dacitic border facies to the senior author in 1948. A. O. Woodford and J. S. Shelton were early guides. Los Angeles Basin subsurface geology became an appreciated resource especially through the work of J. E. Schoellhamer. Data, cores, and cuttings from key wells were crucial to our study. Particular thanks are extended to Leslie Klinchuch and John Urbach (Chevron USA, Inc.), Reon Moag (Union Oil Co. of California), Charles James (Shell Oil Co., Aera Energy LLC), and Russ Robinson (California Well Sample Repository) for crucial well samples. Publications of T. E. Wright, J. S. Hornafius, and E. Hauksson proved invaluable. R. M. Enrico and S. A. Root gave expert paleontological assistance and S. Cook key field assistance. V. A. Frizzell determined and generously provided important radiometric age values. R. E. Denison provided access to petrographic facilities. R. E. Stanley gave encouragement and help. Critical input was provided by R. E. Powell, both in

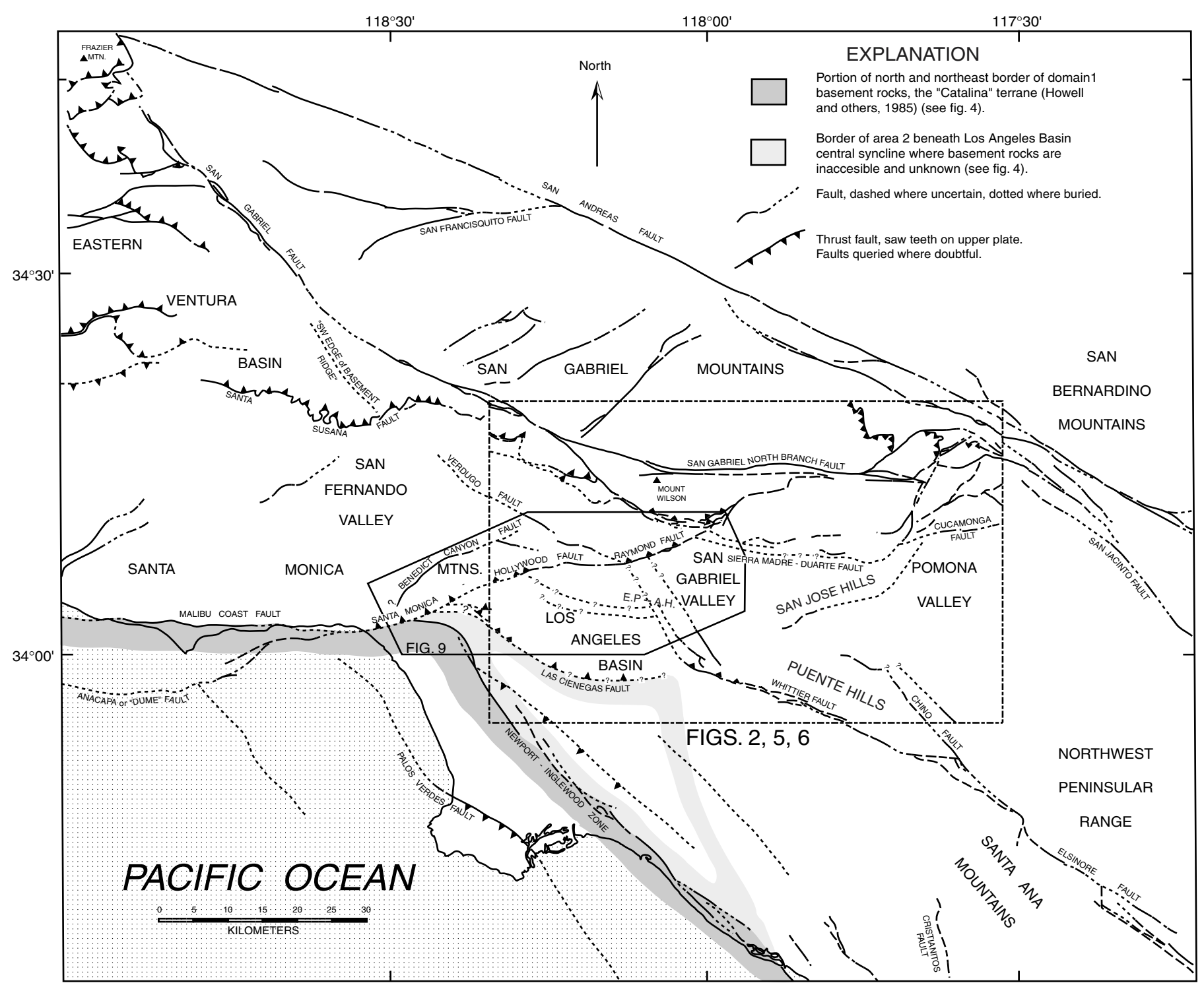

Figure 1.-Principal geographic features and simplified fault map of a part of southern California southwest of the San Andreas Fault Zone. Outlines of our study area (figs. 2, 5, and 6) and of an area covering the Santa Monica-Hollywood-Raymond Hill Fault Zones (fig. 9) are indicated. Partial extents of basement rock domains 1 and 2 (fig. 4) are also shown. EP-AH is the Elysian Park-Monterey ParkAlhambra structural high discussed in text. 
personal conversations and through his encyclopedic publications. Others who helped us include C. L. Powell and Zenon Valin (USGS), Karen Fortus and Steve Bear (U. S. Forest Service), and Rachel Wing (City of Monrovia, California, Parks Division). Helpful USGS reviews were provided by R. H. Campbell, D. M. Morton, and R. E. Powell.

\section{Regional Structural Framework}

Most faults considered in this study are exposed at the surface and have been mapped in greater or lesser detail (Jennings and Strand, 1969). A few are known only from drill hole information augmented partly by interpretations of gravity or seismic reflection data. Evidence of ground-water barriers and studies of earthquake sequences reveal a few additional faults and illuminate the state of stress connected with others. Faults we consider are shown on figure 2 and summarily described in table 1 .

Structural evolution and lithostratigraphic development are interdependent in tectonically active depositional settings. Deciphering either the structural or sedimentary history consequently requires dual approaches. As a starting complement to the fault pattern, figure 2 also shows the present configuration of the basement-sedimentary rock interface. This configuration is based substantially on drill hole and outcrop data northeast of the Whittier Fault Zone and north of the "Monterey Park fault" (Davis and others, 1989; Wright, 1991). Southwest of those structures the configuration is adapted mainly from interpretations of gravity data (McCulloh, 1960; Chai and Hinze, 1988; Langenheim and Jachens, 1996). For

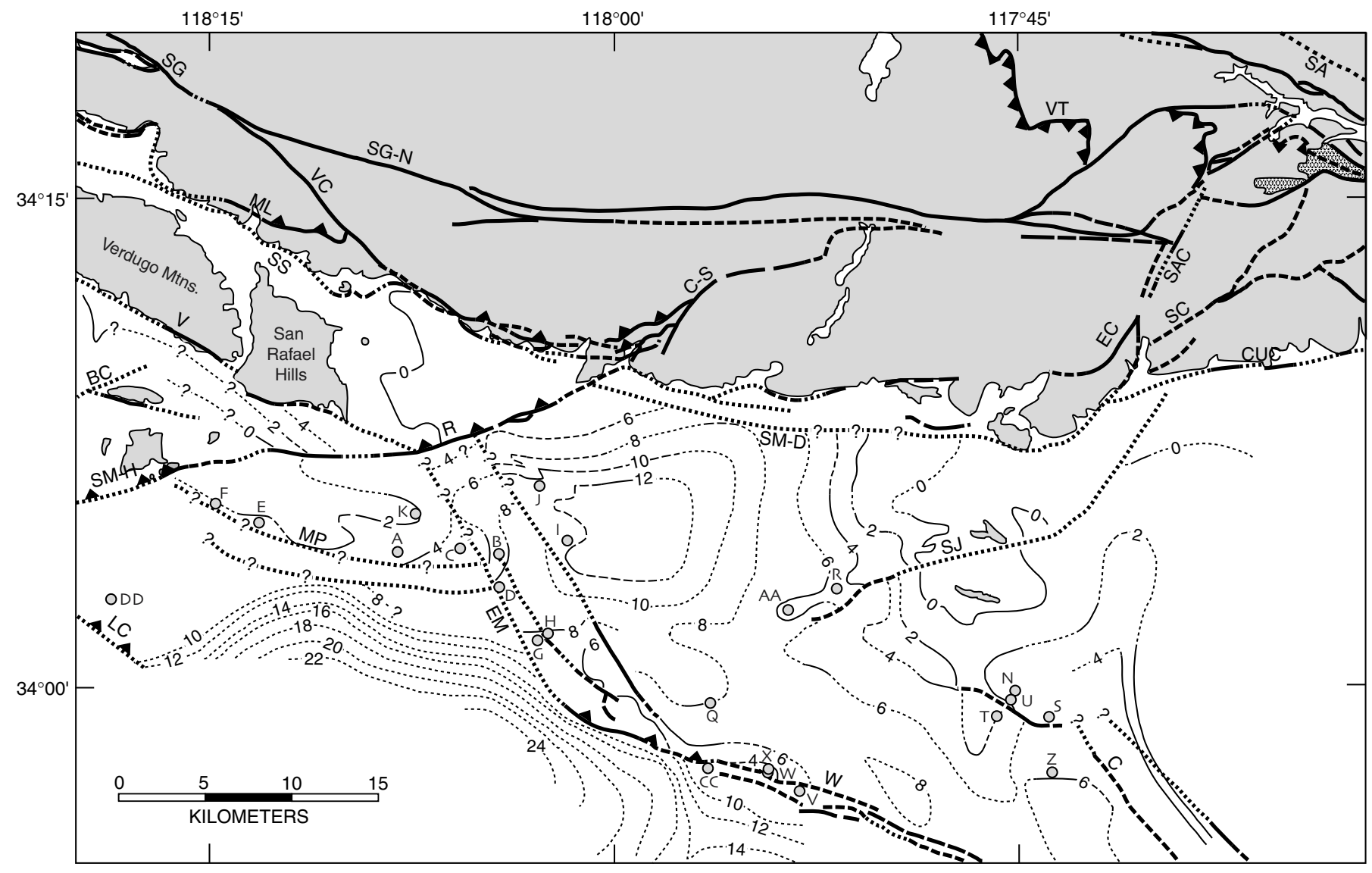

\section{EXPLANATION}

$\begin{array}{lll}\text { Pre-sedimentary basement rock outcrops } & -6 \cdot & \begin{array}{l}\text { Structure contours on base of sedimentary cover } \\ \text { Oligocene Telegraph Peak granodiorite }\end{array} \\ & \text { Z } & \text { (in thousands of feet below sea level) }\end{array}$

Figure 2.- Simplified geologic map of the study area emphasizing surface traces of faults mentioned in the text. Also shown are outcrop areas of basement rocks older than Los Angeles Basin sedimentary cover and outcrops of Telegraph Peak granodiorite (Miller and Morton, 1977), plus a generalized configuration of the base of the sedimentary cover modified from McCulloh (1960), Chai and Hinze (1988), Wright (1991), and Langenheim and Jachens (1996). Fault abbreviations: BC, Benedict Canyon; C, Chino; C-S, Clamshell-Sawpit; CUC, Cucamonga; EC, Evey Canyon; EM, East Montebello; LC, Las Cienegas; ML, Mount Lukens; MP, Monterey Park; R, Raymond (or Raymond Hill); SA, San Andreas; SAC, San Antonio Canyon; SC, Stoddard Canyon; SG, San Gabriel; SG-N, San Gabriel north branch; SJ, San Jose; SM-D, Sierra Madre (includes “Duarte” fault); SM-H, Santa Monica-Hollywood; SS, Santa Susana (eastern extension); V, Verdugo (includes Eagle Rock and San Rafael); VC, Vasquez Creek (also called San Gabriel south branch); VT, Vincent Thrust; W, Whittier. Fault symbols as in figure 1. 
Table 1. Characteristics of faults pertinent to this study, from published sources.

[Fault strike, dip, slip characteristics and movement histories reflect the state of general understanding prior to this study and are based mainly on published literature, tempered in some cases by our knowledge and judgements. Sources of information are not comprehensive and may exclude some pertinent publications. Location of faults are shown in figure 2.]

\begin{tabular}{|c|c|c|c|c|c|c|c|}
\hline Symbol & Name & $\begin{array}{l}\text { Slip characterization } \\
\text { (generally recognized) }\end{array}$ & $\begin{array}{l}\text { Slip or separation } \\
\text { amount }(\mathrm{km})\end{array}$ & Strike & Dip & $\begin{array}{l}\text { Movement } \\
\text { time }\end{array}$ & Sources of information \\
\hline SM-H & $\begin{array}{l}\text { Santa Monica- } \\
\text { Hollywood } \\
\text { Raymond Hill } \\
\text { ("Haymond") }\end{array}$ & $\begin{array}{l}\text { oblique reverse } \\
\text { lefl-lateral } \\
\text { oblique reverse } \\
\text { left-lateral }\end{array}$ & $\begin{array}{l}\text { Estimates range } \\
\text { from "10-15 } \mathrm{km}^{4} \\
\text { to } 90 \mathrm{~km} \text { of loft } \\
\text { slip and } 2.4 \mathrm{~km} \text { of } \\
\text { dip separation }\end{array}$ & $\begin{array}{c}N 80^{+} \mathrm{E} \\
\text { to } \\
N 63^{\prime} \mathrm{E} \\
\mathrm{E} \cdot W \\
\text { to } \\
\mathrm{N} 60^{\circ} \mathrm{E}\end{array}$ & $\begin{array}{c}45^{\circ}-65^{\circ} \\
N \\
75^{\circ}-90^{\circ} \\
N\end{array}$ & $\begin{array}{c}\text { about } \\
7 \text { Ma to present } \\
\text { (also see Wright, } \\
\text { 1991, p. 57-62) }\end{array}$ & $\begin{array}{l}\text { Barbal (1958), Yeats (1968), Lamar } \\
\text { (1970). Yerkes and Campbell }(1971), \\
\text { Colburn (1973), Sage }(1973,1975), \\
\text { Campbe:l and Yerkes (1976). Truex } \\
\text { (1976), Dibblee (1982, 1989), Real } \\
\text { (1987), Jones and others (1990), } \\
\text { Dolan and others (1997). }\end{array}$ \\
\hline SM-D & $\begin{array}{l}\text { Siersa Madre } \\
\text { (and Duarle) }\end{array}$ & $\begin{array}{l}\text { ? oblique reverse } \\
\text { left-Jateral; Ihrust; } \\
\text { or ? ablique reverse } \\
\text { rlght-la leral }\end{array}$ & $\begin{array}{c}\text { "0" or } \\
\text { "aboul } \mathbf{3 8 ~} \mathbf{k m} \text { of } \\
\text { right-lateral; } \\
3 \mathrm{~km} \text { of vertical } \\
\text { separation }\end{array}$ & $\begin{array}{c}N 70^{\circ} \mathrm{W} \\
\text { to } \\
\mathrm{E} \cdot \mathrm{W}\end{array}$ & $\begin{array}{c}12^{\circ}-75^{\circ} \\
N\end{array}$ & $\begin{array}{l}\text { Post } 9 \mathrm{Ma} \\
\text { to present. } \\
\text { "Mid-Miocene" }\end{array}$ & $\begin{array}{l}\text { Sheiton (1955), Proctor and olhers } \\
\text { (1970), Crook and others (1987). } \\
\text { Powell (1993, p. 37), Morton (1973). } \\
\text { Morton and Baird (1975). }\end{array}$ \\
\hline ac & Cucamonga & $\begin{array}{l}\text { reverse } \\
\text { dip-slip }\end{array}$ & uncerlain & $\underset{ \pm}{N 83^{\circ}}$ & $\begin{array}{c}25^{\circ}-40^{\circ} \\
\mathrm{N}\end{array}$ & $\begin{array}{c}\text { Lale Tertiary } \\
\text { to } \\
\text { present }\end{array}$ & $\begin{array}{l}\text { Morton (1975), Morton and Malti } \\
(1987), \text { May and Walker }(1989, p \text {. } \\
1,262) \text {. }\end{array}$ \\
\hline BM & Easl Montebello & $\begin{array}{l}\text { right-lateral } \\
\text { strike stip }\end{array}$ & $\begin{array}{c}\text { maximum of } \\
9 \mathrm{~km}\end{array}$ & $\mathrm{~N} \mathrm{33} \cdot \mathrm{W}$ & $\begin{array}{c}90^{\circ} \\
\text { to } \\
\text { steep NE }\end{array}$ & $\begin{array}{c}\text { Late Tertiary } \\
\text { to } \\
\text { present }\end{array}$ & Wrighl (1991, p. $49.52,89$ ). \\
\hline MP & Monterey Park & $\begin{array}{l}\text { reverse } \\
\text { dip-slip }\end{array}$ & uncertain & $E-W$ & $\begin{array}{l}? 65^{\circ} \\
\mathrm{N}\end{array}$ & $\begin{array}{c}\text { Lale Neogene } \\
\text { to } \\
\text { present } ?\end{array}$ & $\begin{array}{l}\text { Davis and others }(1989), \text { Wright } \\
\text { (1991, figs. } 80,9 \text { and } 10) \text {, Oskin and } \\
\text { others (2000). }\end{array}$ \\
\hline sG & $\begin{array}{l}\text { San Gabriel } \\
\text { (main slrand) }\end{array}$ & $\begin{array}{c}\text { oblique normal } \\
\text { sight-lateral;" "listric" }\end{array}$ & $\begin{array}{l}-60 \mathrm{~km} " \\
42-46 \mathrm{~km}^{\prime \prime} \\
70 \mathrm{~km}^{*} \\
\text { right s\|p }\end{array}$ & $\begin{array}{c}\mathrm{N} 45^{\circ} \mathrm{W} \\
\text { to } \\
\mathrm{N} 65^{\prime} \mathrm{W}\end{array}$ & $\begin{array}{c}45^{\circ} \mathrm{NE} \\
\text { to } \\
\text { near } \\
\text { vertical }\end{array}$ & $\begin{array}{c}15 \mathrm{Ma} \\
\text { to } \\
4 \mathrm{Ma} \pm\end{array}$ & $\begin{array}{l}\text { Ehlig (1973, p. } 249 \text {, and } 1981 \text {, fig. } \\
10-4) \text {. Entert (1982). Enlig and } \\
\text { Crawell (1982), Powall (1993, p. 43- } \\
\text { 44), Way and others (1993, fig. } 7) \text {. }\end{array}$ \\
\hline SG-N & $\begin{array}{l}\text { San Gabriel } \\
\text { North Branch }\end{array}$ & $\begin{array}{l}\text { right-latera: } \\
\text { strike stip }\end{array}$ & 22 to $23 \mathrm{~km}$ & $\begin{array}{c}E-W \\
\text { to } \\
N 65^{\circ} W\end{array}$ & $\begin{array}{c}\text { near } \\
\text { vertical }\end{array}$ & $\begin{array}{c}10 \text { or } 9 \mathrm{Ma} \\
10 \\
7 \mathrm{Ma}\end{array}$ & Enlig (1981, fig. 10-4). \\
\hline
\end{tabular}

most of the area between the Whittier and Sierra MadreDuarte Fault Zones, the present deformed surface was a nearly level erosional surface before about $17 \mathrm{Ma}$. South of the Whittier Fault, and locally also north of the Santa Monica-Hollywood Fault Zone, variable but modest thicknesses of late Cretaceous and Paleogene clastic strata separate an unmapped 17-Ma horizon from the basement interface. However, the structure contours in figure 2 are an approximation of all post-17 Ma differential structural rearrangements because subsidence and sedimentation have dominated much of the area since $17 \mathrm{Ma}$. North of the Verdugo and Sierra Madre-Cucamonga Fault Zones, and partly northwest of the Santa Monica-Raymond Fault Zone, uplift and erosion dominated for all or most of the past 17 million years, and especially since about $4 \mathrm{Ma}$. Much of the Los Angeles Basin porous sedimentary fill (McCulloh, 1960) originated through Neogene to Holocene erosion of the structurally elevated and mountainous tracts to the north.

\section{Basement Rock Units}

Basement rocks that predate the Los Angeles Basin sedimentary cover are a diverse and heterogeneous metamorphic and plutonic assemblage. They range from Early Proterozoic amphibolite and orthogneiss to Early Cretaceous tonalites, granodiorites, and granitic rocks (see, for example, Schoellhamer and Woodford, 1951; Yerkes and others, 1965, p. A21-A24 and fig 5; Yeats, 1973; Ehlig, 1981; Sorensen, 1988; Wright, 1991, fig. 4; Powell, 1993, fig. 8). An overview of these complex assemblages is facilitated by subdividing the region along major tectonic boundaries into natural "tectonostratigraphic terranes" (Howell and others, 1985, p. 4 and fig. 3). Characteristics and locations of the resultant six major areas of strongly contrasting basement rock assemblages are shown in figures 3 and 4, respectively (see also figure 1).

A profound tectonic boundary separates area 4 (the central San Gabriel Mountains, San Rafael Hills, and Verdugo Mountains) from area 3 (the San Fernando-San Gabriel- 
Table 1. Characteristics of faults pertinent to this study, from published sources-Continued.

\begin{tabular}{|c|c|c|c|c|c|c|c|}
\hline Symbot & Faull Name & $\begin{array}{l}\text { silp characiertzotion } \\
\text { (generally recognized) }\end{array}$ & $\begin{array}{l}\text { Slip or saparalion } \\
\text { amount (km) }\end{array}$ & Sirlke & Dip & $\begin{array}{l}\text { Moverniont } \\
\text { time }\end{array}$ & Sources of inlormation \\
\hline ss & Santa Susana & $\begin{array}{l}\text { oblique reverse } \\
\text { |eft-|ateral }\end{array}$ & uncertain & $\begin{array}{l}\mathrm{N} 60^{+} \mathrm{W} \\
\text { to } \\
\mathrm{E}-\mathrm{W}\end{array}$ & ${ }^{15^{\circ}-75^{\circ}}$ & $\begin{array}{l}0.7 \mathrm{Ma} \\
10 \\
\text { present }\end{array}$ & $\begin{array}{l}\text { Allen and others (1975), Crook and } \\
\text { olhers (1987), Smith (1986), Yeats } \\
\text { (1987), Fubin and others (1998). }\end{array}$ \\
\hline C.S & Clamshell-Sawpit & $\begin{array}{l}\text { reverse } \\
\text { dip-slip }\end{array}$ & uncertain & 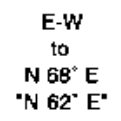 & $\begin{array}{c}35^{*}-70^{\circ} \\
\mathrm{NW} \\
50^{\circ} \mathrm{N}^{n}\end{array}$ & $\begin{array}{c}\text { Late Tertiary } \\
\text { lo } \\
\text { present }\end{array}$ & Morton (1973), Hauksson (1994). \\
\hline $\mathbf{M}$ & Mount Lukens & $\begin{array}{l}\text { reverse } \\
\text { dip-slip }\end{array}$ & $\begin{array}{l}1 \mathrm{~km} \text { of vertical } \\
\text { separalion; } \\
2-4 \mathrm{~km}(?) \text { of } \\
\text { dip-slip }\end{array}$ & $\begin{array}{c}E-W \\
\text { to } \\
N 60^{\circ} W\end{array}$ & $0^{0}-45^{\circ}$ & $\begin{array}{c}\text { Late Tertiary } \\
\text { lo } \\
\text { present }\end{array}$ & $\begin{array}{l}\text { Crook and others }(1987), \text { Smith } \\
\text { (1986), Powell }(1993, \text { p. 37). }\end{array}$ \\
\hline v & $\begin{array}{l}\text { Verdugo } \\
\text { (Eagle Rock) }\end{array}$ & $\begin{array}{l}\text { reverse dip-slip } \\
\text { (initialy normal?) }\end{array}$ & $\begin{array}{l}\text { up } 101.83 \mathrm{~km} \text { of } \\
\text { dip separation }\end{array}$ & $N 65^{\circ} W$ & $<20^{\circ}-90^{\circ}$ & $\begin{array}{c}16 \mathrm{Ma} \pm \\
\text { to } \\
\text { Holocene }\end{array}$ & $\begin{array}{l}\text { Lamar }(1970) \text {. Weber and others } \\
(1980) \text {. }\end{array}$ \\
\hline $\mathrm{BC}$ & Benedict Canyon & $\begin{array}{l}\text { left-dateral } \\
\text { strike slip }\end{array}$ & $\begin{array}{l}2.5 \mathrm{~km} \text { of left } \\
\text { separation }\end{array}$ & $\begin{array}{l}\text { N } 36^{\circ} E \\
10^{\circ} \\
\text { N } 69^{\circ} E\end{array}$ & $\begin{array}{l}\text { noar } \\
\text { vertical }\end{array}$ & $\begin{array}{c}? 15 \mathrm{Ma} \\
\text { to } \\
\text { Qualernary? }\end{array}$ & $\begin{array}{l}\text { Hoots (1991), Durrell (1954), Weber } \\
\text { and others (1980). }\end{array}$ \\
\hline ما & $\begin{array}{l}\text { Las Cienegas } \\
\text { (Huntington Park) }\end{array}$ & $\begin{array}{l}\text { reverse dip slip } \\
\text { (initially normal) }\end{array}$ & $\begin{array}{l}1.2 \mathrm{~km} \text { of dip } \\
\text { sepsration }\end{array}$ & $\begin{array}{c}N 73^{\circ} W \\
\text { to } \\
E-W\end{array}$ & $63^{\circ} \mathrm{NE}$ & $\begin{array}{l}? 15 \mathrm{Ma} \\
\text { lo } \\
6 \mathrm{Ma} ?\end{array}$ & $\begin{array}{l}\text { McMurdie and others (1973), Wright } \\
\text { \{1991, figs. 10, 14). Schneider and } \\
\text { others (1996). }\end{array}$ \\
\hline $\begin{array}{l}\text { EC-SAC } \\
\text { SC }\end{array}$ & $\begin{array}{l}\text { Evey Caryon-San } \\
\text { Antonio and } \\
\text { Stoddard Ganyon }\end{array}$ & $\begin{array}{c}\text { oblique reverse } \\
\text { Ieft-lateral }\end{array}$ & $\begin{array}{c}\text { "about } 13 \mathrm{~km} \text { ' } \\
\text { or } \\
\text { "3 km" of } \\
\text { strike separation }\end{array}$ & $\begin{array}{l}N 29^{\circ} \mathrm{E} \\
10^{\circ} \\
N 65^{\circ} \mathrm{E}\end{array}$ & $60^{\circ} \cdot 80^{\circ}$ & post $7 \mathrm{Ma}$ & $\begin{array}{l}\text { Morlon (1975). May and Walker (1989, } \\
\text { fig. } 12 \text { and p. 1,262), Malti and Morton } \\
(1993, \text { p. 125). }\end{array}$ \\
\hline$c$ & Chino & $\begin{array}{l}\text { oblique reverse } \\
\text { pight-laterai }\end{array}$ & $\begin{array}{c}<2.5 \mathrm{~km} \text { of } \\
\text { slrike separation: } \\
0.7 \mathrm{~km} \text { of } \\
\text { dip separation }\end{array}$ & $\begin{array}{l}N 97^{\circ} \mathrm{W} \\
10 \\
N 50^{\circ} \mathrm{W}\end{array}$ & $\begin{array}{c}65^{\circ}-70^{\circ} \\
\text { Sw }\end{array}$ & $\begin{array}{l}<5 \mathrm{Ma} \\
\text { to } \\
\text { present }\end{array}$ & $\begin{array}{l}\text { Durham and Yerkes (1964, p. B32- } \\
\text { B34), McCulloh and others }(2000) \text {. }\end{array}$ \\
\hline S.J & San Jose & $\begin{array}{l}\text { oblique reverse } \\
\text { left-lateral } \\
\text { (based on seismicity } \\
\text { \& surlace geology) }\end{array}$ & $\begin{array}{l}\quad 0.5 \mathrm{~km} \\
\text { of vertical } \\
\text { separation }\end{array}$ & $\begin{array}{c}N 60^{\circ} \mathrm{E} \\
\left(\mathrm{N} 37^{\circ}-\right. \\
\left.75^{\circ} \mathrm{E}\right)\end{array}$ & $\begin{array}{c}70^{\circ}-83^{\circ} \\
N W\end{array}$ & present & $\begin{array}{l}\text { Woodlord and others (1945). Hauksson } \\
\text { and Jones (1991). }\end{array}$ \\
\hline VT & Vincent Thrust & \multicolumn{6}{|c|}{$\begin{array}{l}\text { This fault predates intrusion of Mountain Meadows Dacite (and equivalent Telegraph Peak granodiorite) } \\
\text { and its influence therefore is indirecl (see Ehlig, 1981, p. 277; May and Walker, 1989, tigs. } 3 \text { and 8). }\end{array}$} \\
\hline SA & $\begin{array}{l}\text { San Andreas Fault } \\
\text { (main break) }\end{array}$ & \multicolumn{6}{|c|}{$\begin{array}{l}\text { The throughgoing breaks of the main San Andreas Faull Zone bypassed the western Transverse Ranges } \\
\text { after about } 5 \mathrm{Ma} \text { and therelore are only indirectly relevant (however, also see Woodburne. 1975). }\end{array}$} \\
\hline
\end{tabular}

Pomona Valleys plus Santa Monica Mountains-Alhambra high-Puente Hills-Santa Ana Mountains and northwestern Peninsular Ranges). Area 4 basement rocks range in age from older Proterozoic to early Late Cretaceous and consist of multiple distinctive and widespread intermediate metamorphic and plutonic units (Ehlig, 1981; Powell, 1993) related to the southwestern North American craton. Area 3 basement rocks are arc-related metasedimentary and metavolcanic units of Jurassic and early Cretaceous age intruded by Early Cretaceous to early Late Cretaceous calc-alkaline plutons like those of the western Peninsular Ranges batholith (Baird and others, 1974, figs. 6-8; Silver and Chappell, 1988). Area 3 rocks older than late Jurassic are not known, and any connection to the North American craton is remote (but see Gastil, 1985, p. 276).

The contrast between basement rocks of area 1 ("Catalina" of Howell and others, 1985, fig. 3) and area 3 (the eastern Santa Monica Mountains) is equally impressive. Area 1 high-pressure glaucophane schist and related greenschists and saussurite gabbro are oceanic. Their initial metamorphism, dated as $115 \mathrm{Ma}$, late Jurassic (Grove and Bebout, 1995), took place at temperatures of $700-800^{\circ} \mathrm{C}$ and pressures appropriate for a depth of about $16 \mathrm{~km}$. In area 3 at about the same time, argillaceous and tuffaceous sediments were being deposited (now the slates, phyllites, and schists of the Santa Monica Formation) and Cretaceous plutons emplaced. The nature and origin of the tectonic boundary between areas 1 and 3 are matters of continuing study (Crouch and Suppe, 1993; Bohannon and Geist, 1998).

Basement rocks beneath the deeply downfolded Los Angeles Basin central synclinal trough have never been sampled. They may be tectonically denuded Catalina Schist (Crouch and Suppe, 1993), middle Miocene volcanic rocks intruded into the axial part of a rifted zone (Redin, 1991, fig. 4), or a floor "developed on stretched and attenuated marginal rocks" or "as a complex of volcanic rocks and sediments" 


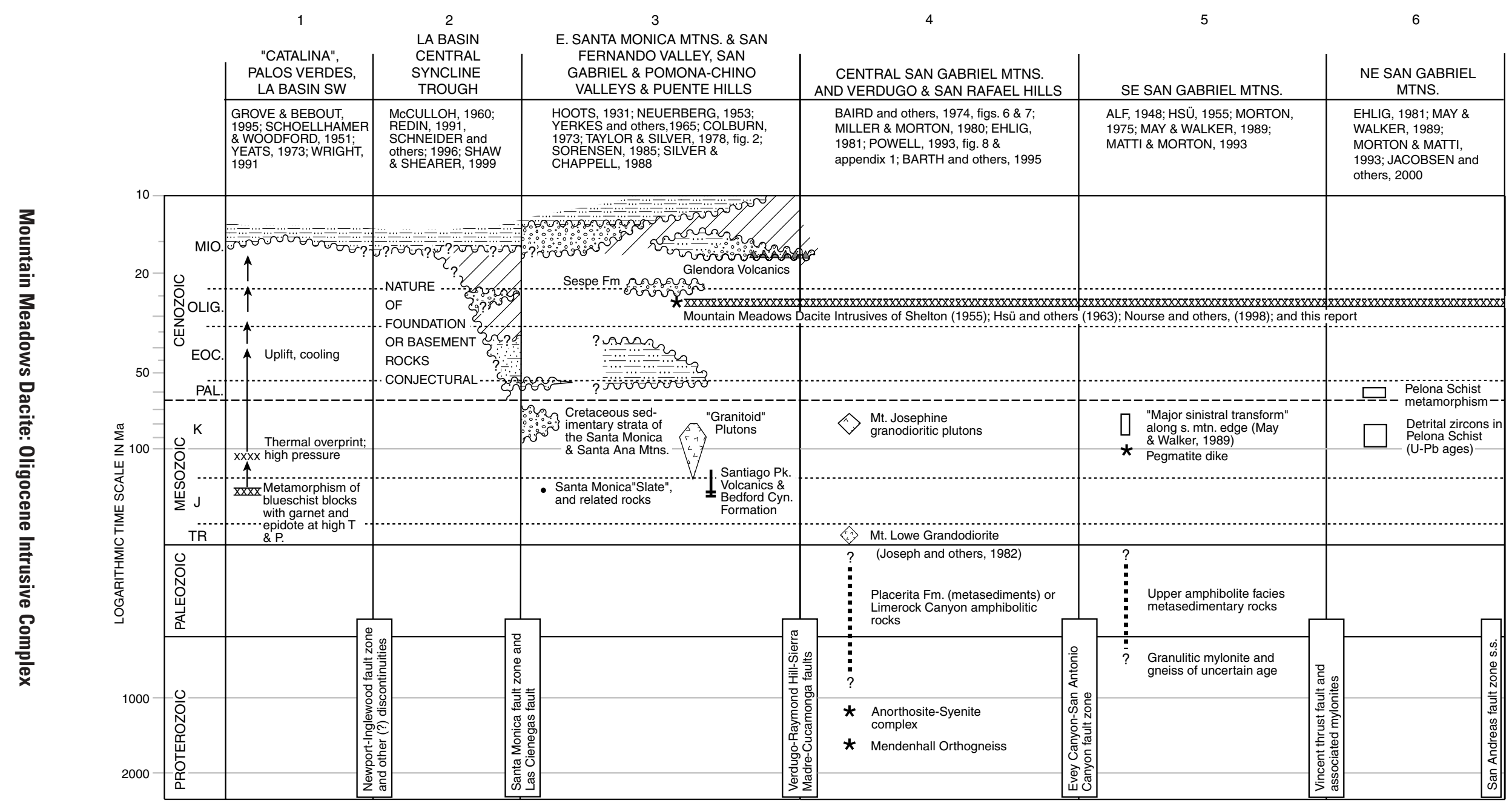

Figure 3.-Basement rock domains and assemblages of the San Gabriel Mountains, the eastern part of the western Transverse Ranges, the Los Angeles Basin, and the northwestern end of the Peninsular Ranges. The nature of the boundaries between domains is also shown. Domain locations and boundaries are shown mainly on figure 4 and partly on figure 1. Each domain is a "tectonostratigraphic terrane" (Howell and others, 1985), a distinct tectonic entity. Note that the Mountain Meadows Dacite and consanguinous latite weld domains 3 through 6 . 
(Crowell, 1974). Alternatively, they might be downfaulted correlatives of the sequence that crops out in the Santa Ana Mountains (Schoellhamer and others, 1981).

Most basement rocks of the southeastern San Gabriel Mountains closely resemble those of the central part of that range. Important differences are the absence, east of the boundary faults, of Triassic Lowe granodiorite and metasyenitic rocks and proved representatives of the Proterozoic suite, and the presence along the southeast edge of the mountain range of a unique suite of synplutonic mylonites and related granulitic gneiss (Alf, 1948; Hsü, 1955; the "Cucamonga terrane" of May and Walker, 1989, figs. 2, 3). Broad similarity of much of this southeastern San Gabriel suite to parts of the eastern Peninsular Ranges prompted Matti and Morton (1993, p. 124-125) to suggest that these rocks originated as part of the Peninsular Ranges and were structurally juxtaposed with the central San Gabriel Mountains. Late Cretaceous or early Paleogene ductile movements (May and Walker, 1989) or Neogene brittle fault displacements (Matti and Morton, 1993, p. 125) might have accompanied juxtaposition. Results of this study suggest that both late Cretaceous and Neogene tectonism may have contributed to the enigmatic assemblage.

The south- to southwest-dipping Vincent Thrust and genetically related overlying mylonites separate basement rocks of both the southeast and central San Gabriel Mountains from muscovite-albite-quartz schist and local greenschist of the Pelona Schist (Ehlig, 1981; Morton and Matti, 1993). The age of metamorphism of the Pelona Schist is thought to be $\geq 65-60 \mathrm{Ma}$ (Jacobson, 1990). U-Pb ages of "detrital zircons" in the schist in the western San Gabriel region are interpreted to be about 90-80 Ma (Jacobson and others, 2000, figs. 2C, 3C). Neither the Pelona Schist nor the associated mylonitic rocks of the Vincent Thrust are intruded by Cretaceous granitoid plutons, even though U-Pb isotope relations in zircons of some nearby plutons yield ages of 90-75 Ma (Silver, 1971) and 88-78 Ma (May and Walker, 1989, p. 1260). These facts, together with the late Turonian age ( $>89 \mathrm{Ma}$ ) of basal fossiliferous marine sedimentary rocks in both the Santa Monica and Santa Ana Mountains, indicate a profound regional tectonic significance for both the Vincent Thrust and the synplutonic mylonite north of the Cucamonga Fault separating areas 3 and 5.

Two occurrences of basement rocks may not fit simply into our tectonostratigraphic terrane scheme (fig. 4). Gneissoid granite and tonalite outcrops north of the San Jose Fault at the eastern edge of the San Jose Hills (Shelton, 1955, p. 54) yielded a questionable $\mathrm{K} / \mathrm{Ar}$ (biotite) age of $96.4 \mathrm{Ma}$ (F. K. Miller, written communication, 1995). The 0.70824 initial strontium isotope ratio (D. M. Morton, oral communication, 1998) fits well with gneissoid rocks north of the frontal faults

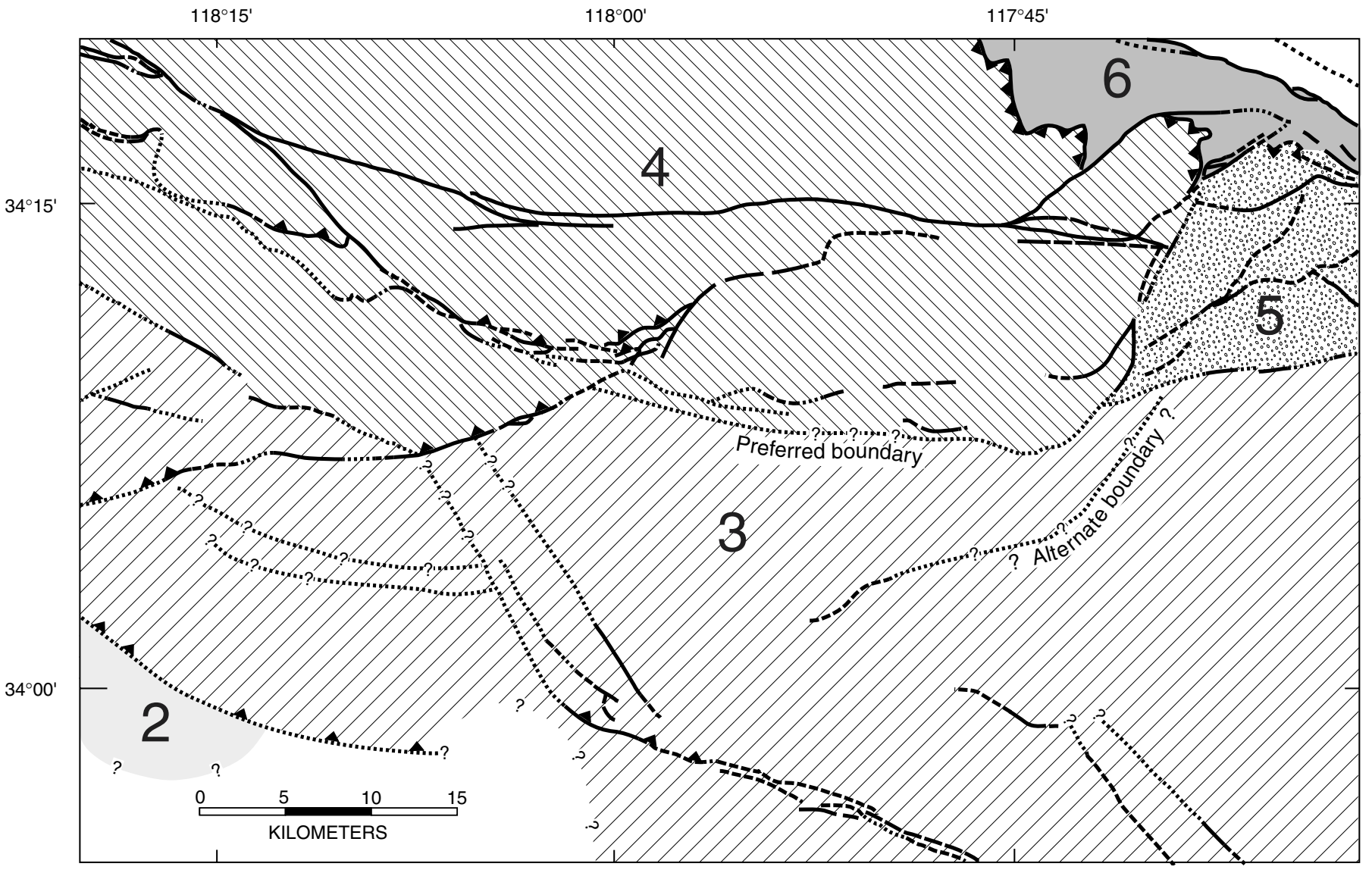

Figure 4.-Areal limits in study area of basement rock domains summarized in figure 3 and discussed in the text. See figure 1 for areal limit of domain 2 and partial extent of domain 1. Fault symbols as in figure 1; see figures 1 and 2 for fault labels. 
of the San Gabriel Mountains and is a misfit with western Peninsular Ranges granitoid rocks (Taylor and Silver, 1978, fig. 2). This singular anomaly, in conjunction with distinctive associated magnetic susceptibility and aeromagnetic response characteristics (D. M. Morton, oral communication, 2000), suggests that the boundary between basement rocks of the San Gabriel Mountains and those of the western extension of the Peninsular Ranges may be hidden beneath the unconformity at the base of the middle Miocene Glendora Volcanics just south of the San Jose Fault (Nourse and others, 1998, p. 10-8). However, any boundary structure south of the questionably dated gneissoid rock must predate the eruption of the volcanics at about $16 \mathrm{Ma}$ and almost certainly the deposition of about 17-million-year-old uppermost Sespe fluvial deposits.

The second possible exception to our basement rock subdivision is an occurrence of metagabbro or metadiorite in drill holes beneath the Las Cienegas oil field on the hanging wall of the north-dipping Las Cienegas Fault (see appendix 1, drill hole no. 19, the "gneissic metadiorite" of Yerkes and others, 1965, p. 424). Thorough studies of this rock unit (Yeats, 1973, p. 134-135; Sorensen, 1985, p. 999; Sorensen, 1988, p. 1005-1012) indicate that it is "albite and oligoclase-epidote amphibolite" derived from an "arc-like" metabasite, possibly related chemically to Jurassic Santa Cruz Island Schist and Jurassic Santa Monica Formation metapelitic rocks and metatuffs. This amphibolite is undated and appears poorly suited for determination of age or initial strontium ratio. Absent more definitive data, we surmise that the rock is most closely related to our extension of the Peninsular Ranges province.

The oldest rock unit common to all parts of the San Gabriel Mountains, the northern Los Angeles Basin, and the northwestern extension of the Peninsular Ranges province is Mountain Meadows Dacite and its relatives. It crosses most of the fundamental tectonic boundaries of our study area, including the Vincent Thrust, the Sierra Madre zone of faults, the north branch of the San Gabriel Fault, and the Vasquez Creek Fault.

\section{Mountain Meadows Dacite}

Innumerable dikes, sills, and irregular discordant bodies of biotite dacite and serially related latite are widespread in the eastern San Gabriel Mountains, where they intrude varied Cretaceous and older metamorphic and plutonic units, both north and south of the San Gabriel Fault (north branch) and east and west of the Evey Canyon-San Antonio Fault Zone (fig. 2). South of the Sierra Madre-Cucamonga Fault Zone, valley alluvium or Cenozoic strata of the Los Angeles Basin succession largely cover both basement rocks and dacite. However, biotite dacite identical to the mountain occurrences crops out locally at the northeastern edge of the San Jose Hills, the type area for the Mountain Meadows Dacite (Woodford and others, 1946), and occurs in surrounding wells (Shelton, 1955) (fig. 5). It intrudes gneissoid granodiorite and granite, and subsurface protomylonitic rocks to the west. Andesitic flows and fragmental volcanic rocks of the Middle Miocene Glendora Volcanics (Shelton, 1955) unconformably overlie both the Mountain Meadows Dacite of the type area and the intruded granitoid rocks. All of these are overlain in turn by a thick to thin sequence of marine strata of the Los Angeles Basin succession that spans the age range from 15.6 Ma (or more) to less than 8.7 Ma (West and Redin, 1991; Wright, 1991, fig. 5).

Mountain Meadows Dacite of the type area is a light gray to tan porphyry. Phenocrysts of euhedral biotite and rounded, partly resorbed quartz bipyramids are conspicuous and distinctive. Roughly equal volumes of normally zoned oligoclase and potassium feldspar prisms are subordinate. A finely crystalline groundmass of feldspar and quartz constitutes the bulk of the rock. Almost identical (but unweathered) rock was cored at a depth of about 1,220 $\mathrm{m}(4,000 \mathrm{ft})$ in drill hole I located about $3 \mathrm{~km}$ southwest of the outcrops (table 2, fig. 5). Biotite from that core gave a K/Ar age of 27.6 0.4 Ma (V. A. Frizzell, oral communication, 1982).

Substantial variations from typical dacite occur among innumerable small to large intrusive bodies in the San Gabriel Mountains. At one extreme are light gray to tan nearly aphanitic rocks, some flow-layered; another extreme is nonfoliated medium- to coarse-grained biotite granodiorite in large discordant stocks in the northeasternmost San Gabriel Mountains (Hsü and others, 1963; Miller and Morton, 1977, p. 644-645). Marginal parts of the stocks consist in places of porphyry identical to Mountain Meadows Dacite. In the westernmost and northeastern parts of the dacite area, quartz-bearing rock grades into texturally very similar latite containing prismatic hornblende phenocrysts, with or without euhedral biotite but generally lacking quartz phenocrysts. Many small intrusive bodies in the mountains consist of fractured and tectonized rock partly altered hydrothermally. Partly or wholly chloritized biotite plus carbonate minerals, sericite, or laumontite (or leonhardite) commonly coat fractures or locally replace plagioclase.

Trains of microscopic fluid inclusions hosting minute mobile vapor bubbles, within partly resorbed quartz phenocrysts where present, are a distinctive characteristic of the most common and abundant dacite. Such fluid inclusions are extremely rare in other rocks of this region and constitute a helpful test of kinship in small clasts, some individual well cuttings, or even clastic grains in younger granule sandstones. Fluid inclusions were not found in quartz of the coarser and more evenly grained Telegraph Peak granodiorite. Most hornblende-bearing latite lacks quartz phenocrysts and therefore lacks such inclusions. Chemical data are unfortunately limited for the dacite (Shelton, 1955; Nourse and others, 1998) and are lacking for the latite.

An unequivocal Oligocene age of emplacement of Mountain Meadows Dacite and its genetic relatives rests on more than nine different radiometric determinations from seven widely separated locations (Hsü and others, 1963; Morton, 1973; Miller and Morton, 1977; V. A. Frizzell, oral communication, 1982; May and Walker, 1989, figs. 2, 8; Nourse and others, 1998; R. J. Fleck, oral communication, 2001). The crystallization age range that best fits all available data is from 27.6 Ma for dacite to 26.3 Ma for Telegraph Peak granodiorite. Dacite is clearly younger than subsurface Upper 
Cretaceous, Paleocene, and Eocene sedimentary rocks south of latitude $34^{\circ} \mathrm{N}$. (McCulloh and others, 2000), but it is older than most or all of the Sespe Formation of this area. The older sedimentary units are not in direct contact with in-place dacite, either in outcrops or in any drill holes. The limits of the basin area known or interpreted to be underlain by strata older than the dacite are less than the limits of the Sespe Formation that are shown on figure 5 (compare with Wright, 1991, fig. 4).

Published data only hint at the areal extent of the dacite intrusive bodies in the San Gabriel Mountains and in the valley region where the Los Angeles Basin succession conceals them (Bellemin, 1940; Shelton, 1955; Morton, 1973; Miller and Morton, 1977; Ehlig, 1981; Evans, 1982; Nourse and others, 1998, fig. 1). No published map shows their areal limits or full extent. Through selective field mapping, extensive field checks, examination of core samples, and careful literature review, we have roughly mapped the westerly limits of the principal regions where dacite or consanguineous latite occurs (fig. 5). Our mapped boundaries are only approximate limits because the abundance of individual intrusive bodies is highly uneven, though with a general decrease toward the west. In the valley region, where rare outcrops are augmented by a few encounters of dacite in drill holes, we define the edge of a subcircular dacite region (see Shelton, 1955, plate 1 and table 3). Here we assume that a singular and coherent large dacite body is defined by the observed occurrences, although a field of many smaller intrusions is equally possible.

Mountain Meadows Dacite and its genetic relatives record an apparently singular igneous episode that predates

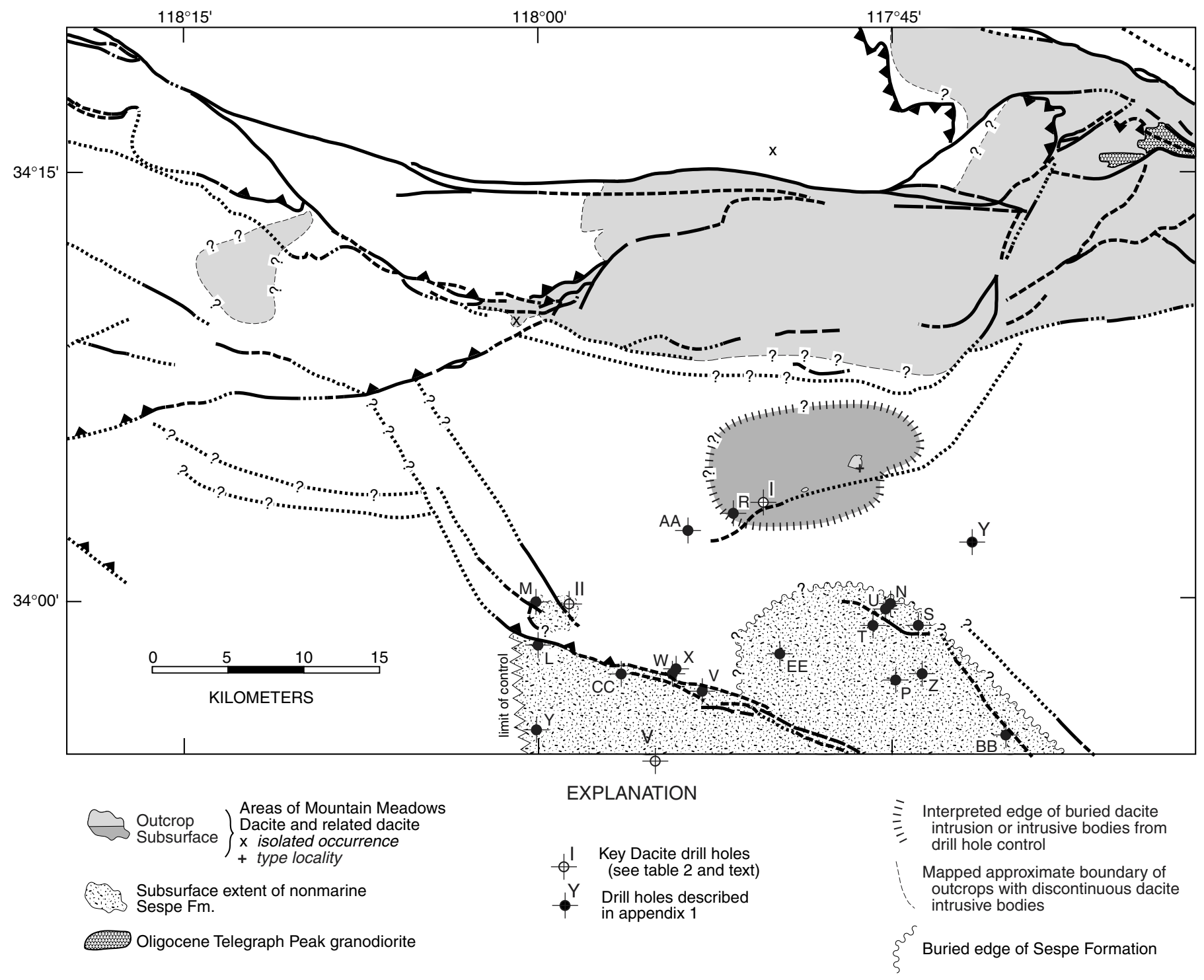

Figure 5.-Areas in which scattered large to small dikes, sills, or irregular intrusive bodies of Mountain Meadows Dacite and consanguinous granodiorite and latite have been observed or mapped. Also shown are areas where subsurface fluvial deposits of the Sespe Formation (and of locally underlying, less extensive marine Paleogene or Upper Cretaceous clastic strata) occur in scattered exploration drill holes (identified in appendix 1). Faults symbols as in figure 1; see figure 2 for fault labels. 
Table 2. Petroleum exploration drills holes discussed in the text and shown on figures 5, 6, or 10 .

\begin{tabular}{|c|c|c|c|c|c|c|c|}
\hline $\begin{array}{l}\text { Map } \\
\text { symbot }\end{array}$ & $\begin{array}{l}\text { Orlginal } \\
\text { operator }\end{array}$ & $\begin{array}{l}\text { Lease name and well } \\
\text { number }\end{array}$ & $\begin{array}{l}\text { Latitude (N.) } \\
\text { Longitude (W.) }\end{array}$ & $\begin{array}{l}\text { Elevation } \\
m(\mathrm{tt})^{1}\end{array}$ & $\begin{array}{l}\text { Total depth } \\
\text { m (ft) }\end{array}$ & $\begin{array}{l}\text { Drill depths of stratigraphic } \\
\text { boundaries } m \text { (ft) }\end{array}$ & Sources of information and comments \\
\hline 1 & $\begin{array}{l}\text { Continental Oil } \\
\text { Co. }\end{array}$ & Bayly No. 1 & $\begin{array}{c}34.9572 \\
117.8418\end{array}$ & $\begin{array}{c}336 \\
\{1,103) \\
{[k b]}\end{array}$ & $\begin{array}{c}1,221 \\
(4,007)\end{array}$ & $\begin{array}{l}\text { Topanga (Relizian equivalent) } \\
\text { Glendora Volcanics, } 645 \pm \text { to } \\
1,183 \pm(2,115 \pm \text { to } 3,880 \pm)_{i} \\
\text { Mountain Meadows Dacite from } \\
1,183(3,880) \text { to total depth. }\end{array}$ & $\begin{array}{l}\text { West and Redin (1991), Shelton }(1955, \mathrm{p} .87) . \\
\text { Core from } 1,184 \text { to } 1,221 \mathrm{~m}(3,885 \text { to } 4,007 \mathrm{ft}) \\
\text { yielded a biotite separale dated by K/Ar as } 27.6 \pm \\
0.4 \mathrm{Ma} \text { (V. F. Frizzell, written communication, } \\
1982) \text {. Samples of conventional core from } 617 \text { to } \\
618 \mathrm{~m}(2,025-2,028 \mathrm{ft}) \text { contain subrounded } \\
\text { pebbles and granules of biotite dacite with } \\
\text { angular clasts of mylonitic rocks and Glendora } \\
\text { Volcanics. }\end{array}$ \\
\hline 11 & $\begin{array}{l}\text { Continental Oil } \\
\text { Co. }\end{array}$ & $\begin{array}{l}\text { Turnbull Community } \\
\text { No. } 3\end{array}$ & $\begin{array}{l}33.9982 \\
117.9793\end{array}$ & $\begin{array}{c}176 \\
(576) \\
{[\mathrm{rt}]}\end{array}$ & $\begin{array}{l}1,709 \\
(5,608)\end{array}$ & $\begin{array}{l}\text { "Sespe?" } 1.676(5.500) \text { to total } \\
\text { depth. }\end{array}$ & $\begin{array}{l}\text { Daviess and Woodiord (1949). Whittier Heights } \\
\text { Fault from } 1,575 \text { to } 1,676 \mathrm{~m}\left({ }^{*} 5,167-5,500^{n} \text { ft). }\right. \\
\text { Petrography indicates that core from this interval } \\
\text { predales Relizian volcanics but contains clasts of } \\
27.5 \text { Ma dacite (this report). }\end{array}$ \\
\hline 111 & $\begin{array}{l}\text { The Texas } \\
\text { Company }\end{array}$ & $\begin{array}{l}\text { Covina Corehole } \\
\text { No. 5-1 }\end{array}$ & $\begin{array}{l}34.0881 \\
117.8620\end{array}$ & $\begin{array}{r}209 \\
(685) \\
{[\mathrm{kb}]}\end{array}$ & $\begin{array}{c}607 \\
(2,000)\end{array}$ & $\begin{array}{l}\text { Puente Fm. (Mohnian) rests on } \\
\text { Topanga Fm. (Luisian) at } 320 \\
(1,050) \text {. Topanga volcanics from } \\
561(1,840) \text { to total depth. }\end{array}$ & $\begin{array}{l}\text { Unusually abundant coccoliths (CN zone 3-4 above } \\
\text { CN zone 3) indicate open marine conditions during } \\
\text { deposition of the Topanga Fm. at this location } \\
\text { (this report). }\end{array}$ \\
\hline IV & $\begin{array}{l}\text { Standard Oil Co. } \\
\text { of Calitornia }\end{array}$ & $\begin{array}{l}\text { Consolidated Rock } \\
\text { Products No. } 1 \\
\text { (original hole) }\end{array}$ & $\begin{array}{c}34.1273 \\
117.9374\end{array}$ & $\begin{array}{r}170 \\
(558) \\
{[d f]}\end{array}$ & $\begin{array}{l}2,394 \\
(7,854)\end{array}$ & $\begin{array}{l}\text { Nonmarine sandstone above } \\
\text { extrusive volcanic rocks at } \\
2,152(7,060) \text {. }\end{array}$ & $\begin{array}{l}\text { Glendora volcanics of probable Relizian age occur } \\
\text { from } 2,152 \mathrm{~m}(7,060 \mathrm{ft} \text { ) to total depth (USGS } \\
\text { files). Clasts of Mountain Meadows Dacite occur } \\
\text { in Luisian sandy conglomerate core at 1,905- } \\
1,910 \mathrm{~m}(6,250-6,267 \mathrm{ft}) \text { (this report). }\end{array}$ \\
\hline$v$ & $\begin{array}{l}\text { Richfield Oil } \\
\text { Corp. }\end{array}$ & Edwards No. 1 & $\begin{array}{l}33.9053 \\
117.9193\end{array}$ & $\begin{array}{c}98 \\
(322) \\
{[\mathrm{kb}]}\end{array}$ & $\begin{array}{l}2,923 \\
(9.591)\end{array}$ & $\begin{array}{l}\text { Tan and red coarse to fine arkose } \\
\text { identified as Vaqueros-Sespe } \\
\text { undifferentiated. }\end{array}$ & $\begin{array}{l}\text { Yerkes (1972, table } 6, p . \text { C46) indicates Sespe } \\
\text { beneath questionable Topanga Formation from } \\
2,910 \text { to } 2,923 \mathrm{~m}(9,546-9,591 \mathrm{ft} \text { ). Coarse } \\
\text { sandstones from } 2,917 \text { to } 2,923 \mathrm{~m} \text { (9,571-9,591 } \\
\text { ft) contain some angular quartz grains of dacite } \\
\text { derivation. }\end{array}$ \\
\hline
\end{tabular}

Depth datum: kb, it, df = kelley bushing, rotary table, derrick floor. 
capture of the Monterey and Arguello Plates (Atwater and Stock, 1998, fig. 10), onset of transrotation of the western Transverse Ranges (Hornafius and others, 1986; Luyendyk, 1990; Nicholson and others, 1994), and opening of Los Angeles Basin. This study investigates the spatial distribution of the intrusives and their relationships to both younger and older formations and to major associated structures to improve understanding of the structural evolution of of the region.

\section{Dacite Clasts in Superjacent Strata}

Mountain Meadows Dacite of the San Jose Hills area was erosionally leveled after about $27 \mathrm{Ma}$, along with the Mesozoic biotite granodiorite and other granitoid rocks into which it was intruded. It is now effectively part of the deformed basement rock surface portrayed in figure 2 .

\section{Sedimentary Rocks Older Than Dacite}

Predacite sedimentary rocks cover the basement rocks in a large subsurface area south of the Whittier Fault and beneath many square kilometers northeast of the fault (McCulloh and others, 2000). These subsurface strata include Upper Cretaceous (locally), Paleocene, and lower Eocene shallow marine to nonmarine clastic beds. Undated coarse fluvial strata of the Sespe Formation overlie the Paleogene units and underlie an even larger area (fig. 5). Marine interbeds of the Sespe gravels are unknown in this area; the northernmost known occurrences of such marine facies (Vaqueros Formation, about $18 \mathrm{Ma}$ or older) are outcrops in the northern Santa Ana Mountains, at least $9 \mathrm{~km}$ south of the area. The age range of the fluvial Sespe deposits is consequently known only through regional correlations and from the ages of underlying and overlying fossiliferous strata. In Santa Ana Mountains outcrops 14 to $22 \mathrm{~km}$ south of the area, terrestrial vertebrate fossils associated with Vaqueros marine fossils show that the youngest part of that section is about $18 \mathrm{Ma}$ (Lucas and others, 1997, p. 3), substantially younger than the dacite emplacement age. The oldest part of the Santa Ana Mountains section may be late Eocene, considerably older than 27.6 Ma.

\section{Dacite Clasts in Pre-Topanga Group Deposits}

Dacite clasts, angular to subrounded and from coarse sand to cobble size, occur in a core of nonfossiliferous sandy conglomerate of the "Sespe (?)" Formation (Daviess and Woodford, 1949) from 1,706 to 1,709 m (5,598-5,608 ft) from drill hole II (table 2, fig. 5). Clasts of biotite dacite and felsite (plus separate individual quartz grains with characteristic fluid inclusions) are Mountain Meadows Dacite products. Associated clasts include metasandstone, biotite-muscovite meta-arkose, massive meta-andesite containing altered amphibole(?) replaced by chlorite, carbonate, and epidote, plus altered plagioclase phenocrysts, granitoid detritus, and a singular subangular clast of metapelite that strongly resembles some specimens of Santa Monica Slate. No clasts of volcanic rocks from the Middle Miocene Topanga volcanics sequences (Shelton, 1955; Eaton, 1958) occur. We conclude that the dacite clasts are in young fluvial Sespe Formation. Subaerial exposure, erosion, and redeposition of nearby dacite prior to Middle Miocene volcanism is demonstrated. The nearest known dacite (subsurface) is about $13 \mathrm{~km} \mathrm{~N} .55^{\circ} \mathrm{E}$. from the well, along a path where postdepositional structural complications are minimal (fig. 5). This suggests a possible early Miocene southwestern paleoslope and drainage system.

One outcrop of Sespe gravels just south of the study area contains clasts of Mountain Meadows Dacite. Subrounded grey dacite clasts as much as $13 \mathrm{~cm}$ long occur in north-dipping uppermost Sespe beds located just north of the southeastern part of the Whittier Fault Zone (33.8323 ${ }^{\circ}$ N., $117.6754^{\circ} \mathrm{W}$.). The most likely source for the clasts, based partly on associated clast lithologies, is about 22 to $25 \mathrm{~km}$ to the north-northwest, possibly the same paleotopographic high that fed clasts to the Whittier Hills well. This suggests a possible southeast-directed paleoslope and drainage system from an elevated region now beneath the northeastern Puente Hills.

Thin sections of coarse sandstones from conventional core recovered from 2,917 to 2,923 $\mathrm{m}(9,571-9,591 \mathrm{ft})$ in drill hole V (table 2, fig. 5) contain some quartz grains derived from Mountain Meadows Dacite, as indicated by their distinctive fluid inclusions with mobile gas bubbles. This is the only occurrence of dacite detritus in Sespe strata that we have found south of the Whittier Fault Zone. Accepting about $9 \mathrm{~km}$ of right slip on the Whittier Fault Zone (McCulloh and others, 2000), the occurrence is consistent with a south-directed paleoslope and drainage system from the area beneath the San Jose Hills.

These occurrences of dacite clasts in Sespe strata, and their inferred derivation from exposed and eroding areas of dacite south of the Raymond, Sierra Madre, and Cucamonga Faults, are evidence that Paleogene and Sespe cover did not extend as far north as those faults in lower Miocene time. Rather, these observations add credence to the interpretation that the present northern edge of Sespe strata (eroded and subsurface) is close to the original edge of the depositional basin (McCulloh and others, 2000). This evidence invalidates previous interpretations of 60 to $90 \mathrm{~km}$ of post-Sespe sinistral slip on the whole Malibu Coast-Cucamonga Fault System (Yeats, 1968, p. 55; Yerkes and Campbell, 1971; Sage, 1973, 1975; Truex, 1976; Campbell and Yerkes, 1976). The three dacite clast occurrences in Sespe strata also indicate that the paleogeography during deposition of the uppermost part of the Sespe Formation in southern California was more complicated than that suggested by Howard (2000).

\section{Nature and Distribution of Topanga Group}

Middle Miocene Glendora Volcanics overlie an erosional unconformity that transects dacite and all pre-Cenozoic foun- 
dation units in the San Jose Hills (figs. 1, 6). The Glendora Volcanics in this area (Shelton, 1955) are the basal unit of an assemblage called the Topanga Group of Wright (1991, fig. 5). Wright's "Topanga Group" is not identical to the "Topanga Group" of Yerkes and Campbell (1979, p. E13) of the central Santa Monica Mountains. Regionally, Wright's Topanga Group comprises basal shallow marine to locally nonmarine coarse clastic sedimentary strata overlain in some places by extrusive basalt, basaltic andesite, and rare silicic flows and fragmental ejecta (mainly marine but locally subaerial) (Shelton, 1955; Eaton, 1958). These are overlain in turn in the San Jose Hills by generally fine-grained open marine units of middle Miocene age that grade or interfinger laterally toward the east and north with coarse and massive conglomerates of eastern and central San Gabriel Mountains derivation. Glendora Volcanics have been dated radiometrically at $16.3 \pm 1$ and $15.9 \pm 0.3 \mathrm{Ma}$ (Nourse and others, 1998, p. 10-2). Overlying marine strata are "Relizian" (17.4-16.5 $\mathrm{Ma}$ ) grading upward into "Luisian" (16.5-14 Ma) (Blake, 1991, fig. 6; West and Redin, 1991). We confirm published benthic foraminiferal stage assignments by using fossil calcareous nannoplankton (nannos) from drill hole III (fig. 6, table 2). Nannos of $\mathrm{CN}$ zone 3 (18.3 to $15.6 \mathrm{Ma}$ ) occur in core from 536 to $540 \mathrm{~m}(1,760-1,770 \mathrm{ft})$, identified by the co-occurrence

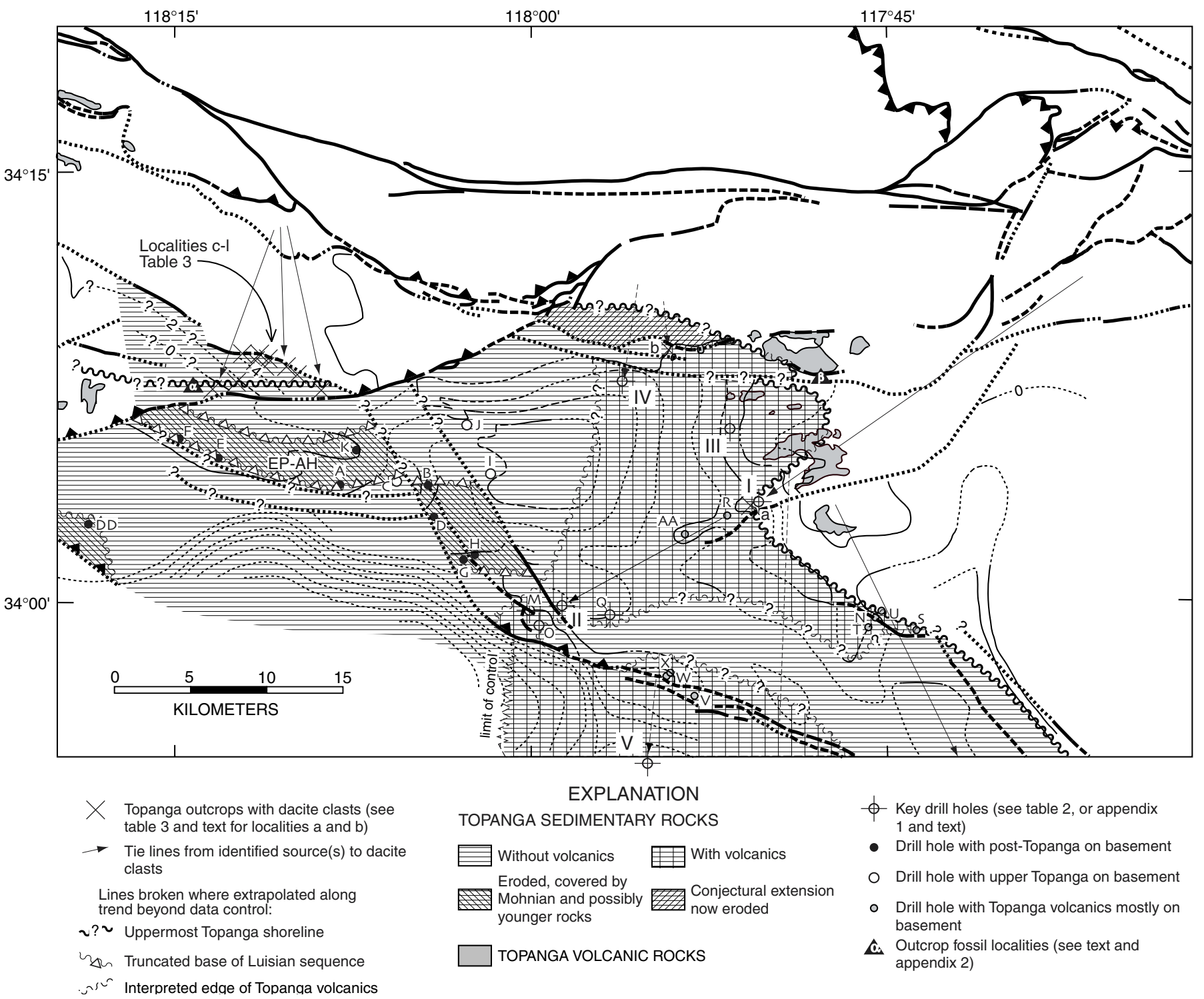

Figure 6.-Distribution of rocks of the Topanga Group (Glendora Volcanics and subsurface Topanga Volcanics overlain by or interbedded with Luisian and locally Relizian marine strata ). Also shown is the approximate location of the uppermost Topanga shoreline as evidenced by the transition from marine to nonmarine deposits. Topanga deposits north of the transition are all nonmarine in the area between the Verdugo and Hollywood Faults. Drill hole and outcrop sites are identified where we have found (1) clasts of Mountain Meadows Dacite (latite) in Topanga conglomerates and (2) calcareous nannofossils that have been studied (tables 2, 3, and appendix 2). Also shown are tielines between dacite clast sites and known (solid) or inferred (dashed) clast sources. Structure contours (unlabeled) as in figure 2. Fault symbols as in figure 1; see figure 2 for fault labels. EP-AH is the Elysian Park-Monterey Park-Alhambra structural high discussed in text. 
of Helicosphaera ampliaperta, Calcidiscus premacintyrei and Reticulofenestra lockeri. This flora is succeeded by another, CN zone 3-4 (>13.6 Ma), that includes Sphenolithus heteromorphus in core from $326-336 \mathrm{~m}(1,071-1,101 \mathrm{ft})$. The location of this drill hole is less than $4 \mathrm{~km}$ from the closest points of the latest Luisian (end Topanga) shoreline as mapped by Woodford and others (1946) and reproduced on figure 6. Details about the nannofloral compositions of each of the horizons we have studied are provided in a complete floral checklist (appendix 2). We choose to follow the locally well known age equivalence of the benthic foraminiferal zonation shown by Blake (1991, fig. 6) even though the time scale that was used (Berggren and others, 1985) has been upgraded (Berggren and others, 1995).

What we know and surmise about the distribution and relationships of units of the Topanga Group are summarized on figure 6. A mostly buried but essentially continuous blanket of Topanga Group volcanic rocks extends from the Whittier Fault northward and northeastward to outcrops in the northeastern San Jose Hills and foothills of the San Gabriel Mountains. Numerous dikes and irregular intrusive bodies of compositionally similar basaltic and andesitic volcanic rocks are widespread in the San Gabriel Mountains (Nourse and others, 1998). Comparable rocks occur also south of the Whittier Fault as subsurface flows that appear to be sandwiched between upper Topanga ("Luisian") marine strata (Gaede, 1957; Eaton, 1958). The extrusive volcanic blanket rests unconformably in different places on Relizian sedimentary rocks (Whittier Hills and just north of the Whittier Fault; Daviess and Woodford, 1949), on Sespe nonmarine gravels (eastern Puente Hills; Durham and Yerkes, 1964), on schistose metavolcanic basement rocks along part of the Whittier Fault hanging wall (Yerkes, 1972), on various other basement rocks beneath the San Jose Hills (Shelton, 1955), and on Mountain Meadows Dacite in and around that unit's type area. No Paleogene or Sespe strata extend beneath the blanket of Topanga Group volcanics to the identified southern boundary faults of the San Gabriel Mountains. Furthermore, the occurrence of Middle Miocene (Relizian) volcanics and marine sediments in the San Jose Hills and also in areas just to the north, across those boundary faults, prohibits any palinspastic reconstruction involving very large post-Lower Miocene strike-slip displacements on those boundary faults, as postulated by Sage (1973, 1975), Truex (1976), and Campbell and Yerkes (1976).

The Topanga Group and its Glendora Volcanics member are thickest (more than 1,220 m or 4,000 ft and $914 \mathrm{~m}$ or $3,000 \mathrm{ft}$, respectively) a few kilometers southwest of their outcrops (Wright, 1991, fig. 5). Volcanics thin rapidly toward the west to an inferred edge beneath unconformable Luisian marine strata under the San Gabriel Valley. They thin rapidly also to the east because of postvolcanic erosion, and they thin to the south through a combination of original thinning and (probably) posteruption erosion. No volcanic rocks are known in the subsurface of the western San Gabriel Valley, or north of the Raymond-Hollywood Fault Zone east of the east end of the Santa Monica Mountains (Lamar, 1970). Volcanic outcrops north of the western Verdugo Mountains and in the easternmost Santa Monica Mountains are of the same approximate age (Eaton, 1958) but of separate eruptive fields.

Where the Topanga Group and Glendora Volcanics are thickest, there is no evidence of a hiatus or depositional change between the Relizian and Luisian parts of the postvolcanic section. Where the volcanics are absent farther west, no Relizian strata are known east of the Santa Monica Mountains. Instead, fine to coarse clastic marine strata yield benthic foraminifers that include Luisian guide species, the nanno Sphenolithus heteromorphus indicating CN zones 3-4 (18.3-13.6 Ma), and fish remains. Luisian beds rest directly on basement rocks without intervening volcanics except in drill hole IV (fig. 6, table 2), which bottomed in altered volcanics beneath nonfossiliferous conglomeratic beds overlain by Luisian marine strata. The evidence suggests (but does not prove) that the Luisian sequence represents a regional marine transgressive episode following much more localized deposition of Relizian marine beds restricted mainly to the area of Glendora Volcanics volcanism and extending south into the eastern part of the main Los Angeles Basin embayment south of the Whittier Fault.

The paleogeography and paleooceanography during deposition of the uppermost Los Angeles Basin Topanga Group (about 15-14 Ma) are known only incompletely and locally (Woodford and others, 1946, fig. 11; Neuerburg, 1953; Nagle and Parker, 1971, p. 270; Dibblee, 1989, p. 218, 220). Major obstacles to comprehensive understanding include postdepositional erosion of extensive proximal areas, widespread structural disruption and distortion, deep burial of extensive areas of distal deposits, thick sections of extremely coarse proximal deposits, and very sparse fossil control in most outcrops. To extend and upgrade understanding of the basin shape, we took the following steps: (1) We mapped a line connecting the most proximal localities where marine fossils occur in outcrops and subsurface locations to approximate the location of the marine-nonmarine transition. (2) Key benthic foraminiferal assemblages were interpreted paleobathymetrically. (3) Nannos were studied quantitatively to gain understanding of the distribution of open marine and upwelling conditions in the late Topanga seaway. (4) Clasts derived from Mountain Meadows dacite-latite intrusives were identified in outcrops and well cores of Topanga Group conglomerates and tied to dacite source locations. Each step yielded positive results.

The early Middle Miocene marine incursion culminated with deposition of latest Luisian conglomerates, sandstones, and open marine siltstones of the northernmost Los Angeles Basin that extended as far northeast as the San Gabriel Mountain front east of the junction of the Raymond and Sierra Madre Faults. The Luisian sea flooded the southern margin of what is now the mountain range even while more elevated parts of the ancestral range were shedding coarse detritus into the basin margin. Coarse Topanga conglomerates (with some breccias) also occur south of the Verdugo Fault Zone and interfinger with marine bathyal Luisian sandy siltstones north of the Raymond Fault (Lamar, 1970, his "York Ave. fault"). Coarse conglomerates with locally derived breccias occur above Topanga volcanics in the easternmost Santa 
Table 3. Outcrop localities where clasts of Mountain Meadows Dacite or related latite and felsite occur in conglomerates of the Topanga and Sespe Formations (figs. 6, 10).

\begin{tabular}{|c|c|c|c|c|c|}
\hline $\begin{array}{c}\text { Symbol } \\
\text { in } \\
\text { figure } 6\end{array}$ & $\begin{array}{l}\text { Latitude (N.) } \\
\text { Longitude (W.) }\end{array}$ & Brief petrographic description & $\begin{array}{l}\text { Clast } \\
\text { abundance }\end{array}$ & $\begin{array}{l}\text { Observed } \\
\text { clast } \\
\text { maximum } \\
\text { size }(\mathrm{cm})\end{array}$ & $\begin{array}{l}\text { Clast } \\
\text { roundness }\end{array}$ \\
\hline a & $\begin{array}{c}34.0635 \\
117.0748\end{array}$ & $\begin{array}{c}\text { Biotite dacite associated wilh mylonites and ultra- } \\
\text { mylonites (among others). }\end{array}$ & common & 7.5 & $\begin{array}{l}\text { rounded } \\
\text { to } \\
\text { subrounded }\end{array}$ \\
\hline $\mathrm{b}$ & $\begin{array}{l}34.1466 \\
117.9023\end{array}$ & $\begin{array}{l}\text { Altered biotite dacile with calcitized plagiociase and } \\
\text { biotile phenocrysts. }\end{array}$ & rare & 30 & subangular \\
\hline$c^{1}$ & $\begin{array}{l}34.1249 \\
118.1466\end{array}$ & $\begin{array}{l}\text { Hornblende biotite latite grading to biotite latite, } \\
\text { some showing flow layering. }\end{array}$ & common & up to 7.5 & $\begin{array}{c}\text { rounded } \\
\text { to } \\
\text { subangular }\end{array}$ \\
\hline$d^{1}$ & $\begin{array}{l}34.1324 \\
118.1649\end{array}$ & $\begin{array}{l}\text { Hornblende biotite latile and dacite, some showing } \\
\text { llow layering. }\end{array}$ & common & 2.5 & $\begin{array}{c}\text { subrounded } \\
\text { to } \\
\text { rounded }\end{array}$ \\
\hline$e^{1}$ & $\begin{array}{l}34.1433 \\
118.1827\end{array}$ & Hornblende biotite latite grading to dacite. & common & up to 5 & subangular \\
\hline$f^{1}$ & $\begin{array}{l}34.1384 \\
118.1856\end{array}$ & Hornblende biotite latite grading to nornblende latite. & scarce & up to 15 & subrounded \\
\hline$g^{1}$ & $\begin{array}{l}34.1438 \\
118.1880\end{array}$ & Hornblende biotite latite. & rare & up to 4 & subrounded \\
\hline$h^{1}$ & $\begin{array}{l}34.1419 \\
118.1894\end{array}$ & Felsitic brotite latite & rare & 2.5 & rounded \\
\hline$i^{\prime}$ & $\begin{array}{l}34.1381 \\
118.1706\end{array}$ & Hormblende latite and hornblende biotite latite. & rare & 5 & $\begin{array}{l}\text { well } \\
\text { rounded }\end{array}$ \\
\hline $\mathbf{j}^{1}$ & $\begin{array}{c}34.1451 \\
118.2026\end{array}$ & Hornblende biotile latite. & rare & 2 & $\begin{array}{l}\text { well } \\
\text { rounded }\end{array}$ \\
\hline$k^{\prime}$ & $\begin{array}{c}34.1273 \\
118.2056\end{array}$ & Hornblende latile. & rare & 2 & $\begin{array}{l}\text { well } \\
\text { rounded }\end{array}$ \\
\hline 'ין & $\begin{array}{c}34.1242 \\
118.2236\end{array}$ & Felsitic biotile latite. & $\begin{array}{l}\text { very } \\
\text { rare }\end{array}$ & 1 & $\begin{array}{l}\text { well } \\
\text { rounded }\end{array}$ \\
\hline$m^{2}$ & $\begin{array}{c}33.8323 \\
117.6754\end{array}$ & Biotite dacite with minor hornblende & common & 13 & subrounded \\
\hline
\end{tabular}

1 Shown as unlabeled $x$ 's south of the Verdugo Fault in figure 6.

? Shown in tiguro 10. One discovered occurrence in Sespe Formation outcrop.

Monica Mountains and were clearly derived from the north or northeast (Dibblee, 1989), but apparently in part also from southeast of the Benedict Canyon Fault (fig. 6).

\section{Dacite Clasts in Topanga Group Conglomerates}

Clasts of Mountain Meadows Dacite and latite occur in strata of the Topanga Group in five widely separated places of our map area. Dacite pebbles were also reported by Shelton
(1955, p. 54) at two unspecified localities in basal members of the Glendora Volcanics that we assume are of local derivation in the dacite type area.

Outcrops of Upper Topanga "Buzzard Peak" pebble to boulder conglomerate (Woodford and others, 1946) in the core of an anticline north of the western part of the San Jose Fault (locality a, fig. 6 and table 3) contain a wide range of basement and volcanic rock clasts, among which very dark to black flinty mylonite and light-colored subangular to subrounded clasts of dacite are minor but conspicuous 
components. Nearby drillhole I (fig. 6) penetrated $645 \mathrm{~m}$ $(2,115 \mathrm{ft})$ of Luisian and Relizian conglomerate plus 538 $\mathrm{m}(1,765 \mathrm{ft})$ of Glendora Volcanics before reaching in-place Mountain Meadows Dacite at 1,183 m (3,880 ft) (Shelton, 1955, table 3; West and Redin, 1991). The conglomerate interfingers in the subsurface to the southwest and north with fine-grained Luisian and Relizian marine sequences of the Los Angeles Basin succession. Subrounded clasts of Mountain Meadows-type dacite occur in conventional core samples from 617 to $618 \mathrm{~m}(2,025-2,028 \mathrm{ft})$ together with angular clasts of Glendora Volcanics and mylonitic rocks. These are from the inferred Relizian part of the section, presumably older than $16 \mathrm{Ma}$. All the data are consistent with clast derivation from the "black belt" mylonite (Alf, 1948), presently $22 \mathrm{~km}$ or more to the northeast (fig. 6) along the front of the southeastern San Gabriel Mountains. The clasts tie together the Relizian-Luisian depositional basin edge and the early-elevated ancestral San Gabriel Mountains (area 5, figs $3,4)$.

Outcrops of Upper Topanga conglomerate near the range front north of the San Gabriel Valley (locality b, fig. 6 and table 3) are interbedded with Glendora Volcanics (Shelton, 1955, plate 1; Morton, 1973; Crook and others, 1987). Steeply dipping very coarse but well-stratified polymictic boulder to cobble sandy conglomerate and sandstone contain a subrounded boulder of calcitized dacite $30 \mathrm{~cm}$ in diameter. Associated with the rare dacite are angular to subrounded clasts of a wide range of the basement rock types from the mountains to the north plus infrequent clasts of basaltic or andesitic volcanic rocks like those of the Glendora Volcanics. Clast sizes and shapes, poor sorting, proximity to the most northerly break of the Sierra Madre Fault Zone at the mountain front, and clast compositional heterogeneity all suggest proximity to sources in a rapidly eroding terrain. Underlying beds (including both volcanic and clastic units) continue downdip to the south and dictate that the eroded sources were to the north. "Upper middle Miocene foraminifera" (presumably Luisian) are reported from the younger part of the sequence (Shelton, 1955, p. 67) and show that the shoreline lay still farther north at the time of deposition. The occurrence ties together the northern edge of the Los Angeles Basin at or before about $14 \mathrm{Ma}$ and an uplifted and eroding part of the ancestral central San Gabriel Mountains (area 4, figs. 3,4$)$ within the area of mapped dacite intrusives.

Drill hole IV reached a depth of 2,394 m (7,854 ft) south of the Duarte branch of the Sierra Madre Fault Zone (fig. 6, table 2). It bottomed in altered basalt (Glendora Volcanics) beneath a thick sequence of generally poorly sorted sandstones with interbedded conglomerates and minor marine siltstones. Petrographic study of core samples from a depth of 1,905-1,910 m (6,250-6,267 ft) identified clasts of Mountain Meadows-type dacite among others of both granitoid and volcanic derivation. The 13.7-Ma "zonal" boundary given by the drill hole operator at about $1,689 \mathrm{~m}(5,540 \mathrm{ft})$ is in a steeply dipping $\left(53^{\circ}\right.$ to $\left.68^{\circ}\right)$ sequence of interbedded fine-grained sandstone and organic-rich siltstone (table 2). This interpretation is supported by the rarity of the nanno Reticulofenestra pseudoumbilica $(>7 \mu \mathrm{m})$, which suggests a position close to the $\mathrm{CN} 4-5$ a zonal boundary based on the bioseries summary by Young (1998). Nannos and abundant fossil fish debris suggest a probable open marine environment with active upwelling.

When plotted on a graph of the Fisher alpha index (Murray, 1973), nanno diversity (1.1 to 1.6) in this drill hole (fig. 7A) compares well with other Los Angeles Basin nanno floras and with modern samples from the southern California Borderland (Winter, 1985). The average diversity of our Los Angeles Basin samples is greater than occurs today in both Belize back reef environments (Kling, 1975) and the south Atlantic offshore Namibia (Giraudeau and others, 1993). The abundance of Coccolithus pelagicus in our floras is probably an indicator of cold water upwelling and enhanced productivity. Such a relationship is supported in a ternary plot of the Los Angeles Basin species (fig. 7B) using Emiliania huxleyi as a modern substitute for the dominant species in the Los Angeles Basin floras, Dictyococcites productus. The proportion of $C$. pelagicus in Los Angeles Basin samples is comparable to the proportion in samples from upwelling waters of Namibia (Giraudeau and others, 1993) but not in samples from southern California Borderland waters (Winter, 1985; Ziveri and others, 1995). Even the two Los Angeles Basin samples dominated by $C$. pelagicus are analogous to a modern sediment population from cold waters of the Greenland Sea (Samtleben and others, 1995), but the dominance may also be an artifact of dissolution enrichment (Berger, 1973; Roth and Coulbourn, 1982). The alternative view that the ecologic limitation of C. pelagicus in the middle Miocene (Bukry, 1981) was much broader than the $10^{\circ} \mathrm{C}$ optimum limit (McIntyre and others, 1970) needs more study. In the upwelling off southwest Africa (Giraudeau, 1992) and western Iberia (Cachao and Moita, 2000), C. pelagicus is thriving where sea surface temperatures average higher than $16^{\circ} \mathrm{C}$. The samples from drill hole IV accumulated in sediment deposited probably at least $4-5 \mathrm{~km}$ from the paleoshoreline, on the basis of the distance from the mapped shoreline of similar floras in drill hole III (table 2, fig. 6).

Dacite clasts of drill hole IV occur in beds that can be no younger than $15.6 \mathrm{Ma}$. The basalt cored in this drill hole is the most northwesterly known Los Angeles Basin occurrence of Glendora Volcanics. The clasts tie the site to one part of the uplifted ancestral San Gabriel Mountains, while the basalt and open marine Topanga tie it to the Los Angeles Basin. The tie raises fundamental questions about amounts, directions, and timing of slip on the Sierra Madre Fault and other related faults such as the Vasquez Creek and San Gabriel (main strand).

Pebbles to cobbles of dacite and consanguineous latite occur at multiple sites in thick and very coarse Topanga conglomerates south of the Verdugo Fault Zone (Lamar, 1970) and north of the Raymond-Hollywood Fault Zone. The localities occur in a belt more than $2.4 \mathrm{~km}$ from east to west (sites c through 1, table 3 and fig. 6). Accepting the validity of published structure sections (Lamar, 1970, plate 2), clastbearing outcrops range from very near the base to about 1,400 $\mathrm{m}(4,600 \mathrm{ft})$ above the base of the Topanga sequence. The overwhelming majority (probably more than 99 percent) of 
the associated clasts are granitoid (granite to granodiorite), although rare andesitic clasts occur, together with even rarer quartzite, gneiss, and diorite. The tan to light green dacite-

A

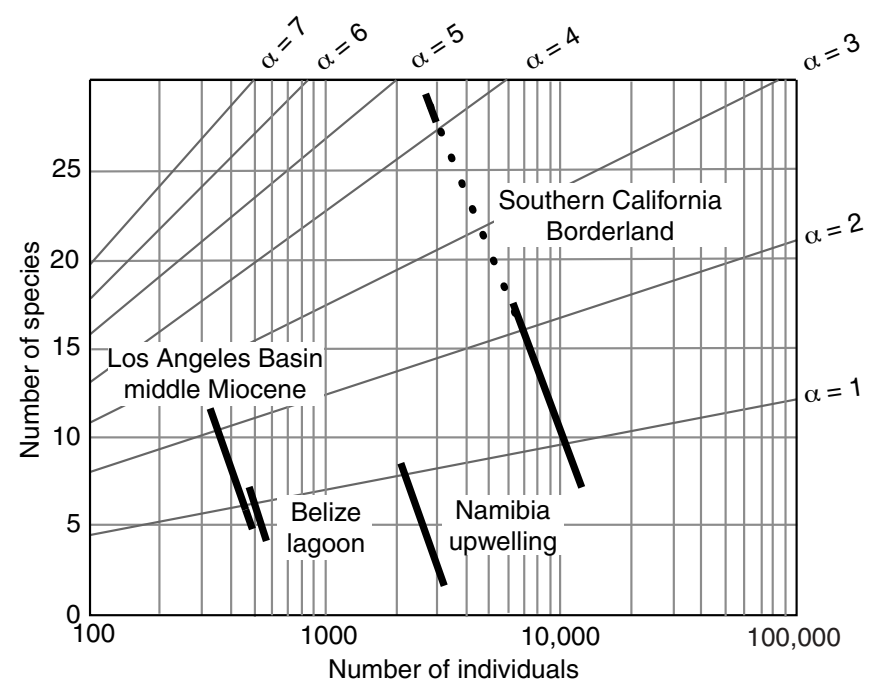

$B$

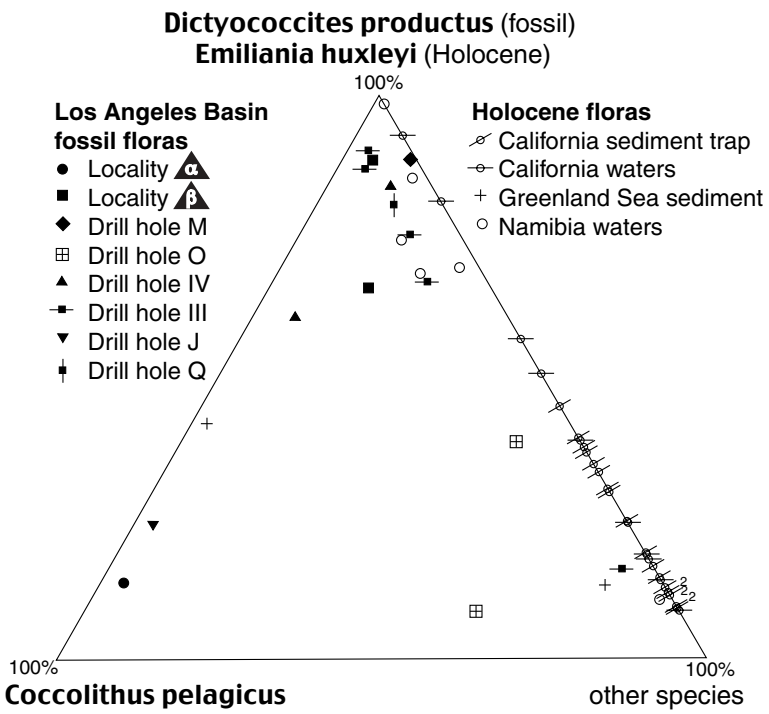

Figure 7.-Comparisons of middle Miocene Los Angeles Basin calcareous nannofossil floras with modern equivalents from selected marine settings. $A$, Crossplot of number of species versus number of individuals, showing "Fisher alpha indices" (Murray, 1973, p. 8, fig. 4) for the Los Angeles Basin fossil floras compared with floras living in modern ocean settings of the southern California Borderland, Namibia upwelling regions, and a Belize back reef lagoon. Floras from offshore Iberia and the Greenland Sea could not be plotted because the abundances of all taxa from these areas were not reported. $B$, Ternary diagram comparing the Los Angeles Basin floras with floras living in open marine settings of the southern California Borderland, Greenland Sea, and Namibia upwelling regions to illustrate possible environmental implications of the Los Angeles Basin fossil assemblages. Ratios for offshore Iberian floras could not be calculated because the abundance of E. huxleyi was not recorded. For locations of Los Angeles Basin sites, see figure 6 and tables. latite clasts are porphyries mostly rich in biotite but generally without quartz phenocrysts. Many contain dark stubby euhedral hornblende prisms in addition to biotite euhedrae. Most clasts are well rounded to subrounded. No such clasts were found in sparse exposures west of the localities shown on figure 6 .

Marine fish scales recovered from fine-grained interbeds in a conglomerate, breccia, and sandstone sequence from site $\alpha$ (fig. 6) were identified as upper Luisian (Lamar, 1970, fig. 9). A well-preserved upper Luisian benthic foraminiferal fauna from this locality suggests an upper bathyal depositional environment near a shelf edge (R. J. Enrico, written communication, 2000). Associated nanno floras are CN 3-4 and indicate an age of 18.3-13.6 Ma.

A reconnaissance search for dacitic intrusive bodies in the southeastern San Rafael Hills (directly north of the Topanga conglomerate clasts) yielded none. Farther north and northwest, in an area about $2 \mathrm{~km}$ east and $2 \mathrm{~km}$ west from $118^{\circ} 12.5^{\prime}$ W. (fig. 5), widely spaced dikes of dacite porphyry contain conspicuous quartz phenocrysts and either lack or have only very subordinate hornblende. They are therefore unlike most of the dacite-latite clasts in the Topanga conglomerates south of the Verdugo Fault. However, still farther north, dikes of hornblende-biotite latite or dacite (Crook and others, 1987, plate 2.1) match closely the conglomerate clast lithologies and occur in a limited area southwest of the Vasquez Creek and Mount Lukens Faults but north of the eastward extension of the Santa Susana Fault (Figs. 2, 5). Another important tie is thereby established between the eroding ancestral southwestern part of the central San Gabriel Mountains and a peripheral part of the subsiding northwestern Los Angeles Basin. This connection predates 14 Ma (the younger bound of the Luisian "stage") and questionably postdates ca. 16.5 Ma. Paleogeographic and paleostructural implications of this finding, and the other occurrences of dacite clasts in superjacent strata, are outlined in the next major section.

\section{Dacite Clasts in Post-Topanga Group Strata}

A major unconformity or regressive discontinuity marks the top of the Topanga Group in most parts of the Los Angeles Basin, including much of the study area. Basal strata of the Puente Formation (or younger units) that rest above the unconformity generally are part of the Los Angeles Basin succession that contains benthic foraminifers of age 14.0 to 13.5 Ma. This horizon is conspicuous because it follows a regressive discontinuity and precedes a regional marine transgression during which a widespread blanket of organicrich and generally fine-grained phosphatic and diatomaceous siltstones and mudstones, with more or less interbedded sandstone, was deposited. Virtually basinwide (Wright, 1991, fig. 10), this transgressive pulse culminated near 8.7-7.0 Ma, probably the maximum Neogene ocean incursion for this part of California (Woodford and others, 1946, fig. 11).

Deformation plus uplift and erosion of the Elysian ParkMonterey Park-Alhambra structural high (EP-AH, figs. 1, 6) 
before $13 \mathrm{Ma}$ is evidenced by the unconformity that separates middle and upper Miocene marine strata of the Puente Formation from older rocks. Uplift led to localized erosional removal of all pre-Mohnian strata along the high as shown by figure 6. The gap attests to an early origin for the "Elysian Park Thrust and Fold Belt" (Shaw and Shearer, 1999), which continues active (Oskin and others, 2000) and is therefore of considerable current interest to seismologists.

Clasts derived from "Mountain Meadows Dacite" were recognized in some outcrops of deformed Los Angeles Basin strata long ago (Bellemin, 1940; Woodford and others, 1945; Woodford and others, 1946; Olmstead, 1950) but most of those occurrences are in Puente Formation or younger strata. Post-Topanga uplift, erosion, and redeposition after both secondary and primary transport make interpretation of these younger dacite clasts difficult and beyond the scope of this study. The stratigraphic relationships described in preceding sections are shown in figure 8, where stratigraphic positions of dacite sources and clasts in Los Angeles Basin Sespe and Topanga Group strata of Wright (1991) are related in a time framework to our interpretations of fault movements.

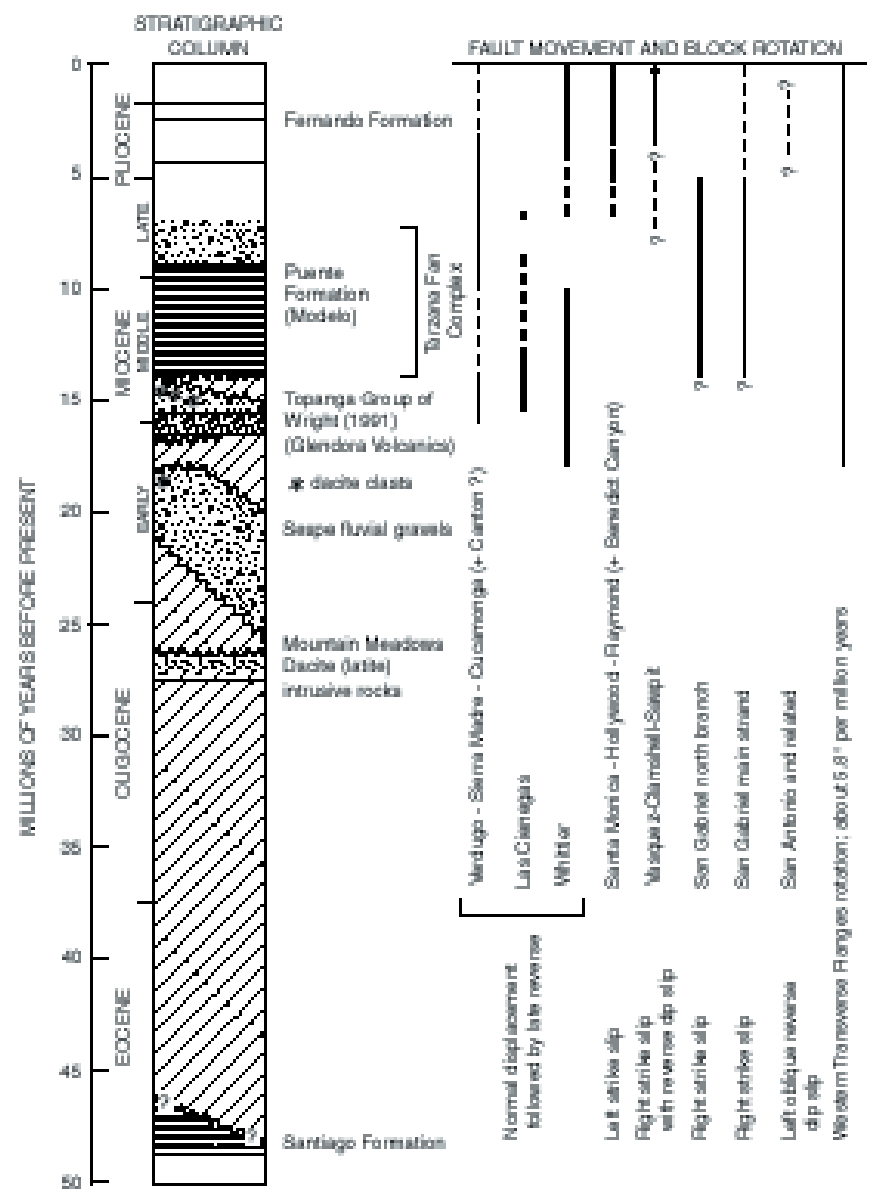

Figure 8.-Graphic summary of the timing of Mountain Meadows Dacite intrusion, northeastern Los Angeles Basin sedimentary deposition, and deposition of dacite-latite clasts relative to fault movements and tectonic rotation of the entire western Transverse Ranges Province.

\section{Upper Topanga Strandline Reconstruction}

Upper Topanga strata in the Los Angeles Basin south of the Monterey Park Fault Zone generally are a fine-grained, offshore open-marine facies. Before this study, the transition from marine to nonmarine facies had been mapped only at the northeastern basin margin (Woodford and others, 1946, fig. 11). As indicated above, Upper Topanga strata are extremely thick and very coarse near the north and northeast basin margins. This, together with post-Topanga structural disruption, has discouraged definition and mapping of the marine-terrestrial transition. Because a transition or shoreline facies is important in our palinspastic reconstruction, we define a late Luisian strandline by (1) adopting and verifying the "Topanga shoreline" of Woodford and others (1946, fig. $11),(2)$ extending that line to the west using interpretation of nanno occurrences and assemblages from key wells, and (3) generating an equivalent facies boundary in the area of Topanga outcrops south of the Verdugo Fault by focusing on the distribution limits of marine fossil localities and paleoecological interpretations of fossil assemblages (Lamar, 1970, fig. 9; this report). The resulting approximate shoreline is shown on figure 6.

The approximate distribution of Miocene strata younger than the Topanga Group (<14 Ma) is shown for the northeasternmost basin edge by Woodford and others (1946, fig. 11), along with their best estimates of the locations of younger Miocene shorelines. Other published approximations are extremely generalized and unsupported by specific data (Schwartz and Colburn, 1987, fig. 3; Wright, 1987, fig. 4).

\section{Palinspastic Reconstruction}

Our interpretation of the paleogeographic and paleostructural evolution of the study area uses (1) fault separations or offsets and movement histories of key major faults; (2) areal distribution of Mountain Meadows Dacite (and related) intrusive bodies; (3) locations of dacite clasts in Los Angeles Basin superjacent strata older than $14 \mathrm{Ma}$; (4) available subsurface geological and geophysical data that constrain timing and nature of fault movements or offsets, including published seismological data; and (5) published interpretations of paleomagnetic declinations that could be influential.

\section{Santa Monica-Hollywood-Raymond Fault Zone}

The Santa Monica-Hollywood-Raymond zone of faults (fig. 2) is central to our study. An oblique reverse leftlateral fault zone that records significant cumulative left slip (Wright, 1991, p. 56-63), it separates upthrown Santa Monica Mountains from the structurally depressed northwest part of the Plio-Pleistocene Los Angeles Basin depocenter and is seismically active (Real, 1987; Jones and others, 1990; Dolan and others, 1997, 2000). The trace of the part of the fault shown on our maps is based importantly on surface geologic 
mapping (Weber and others, 1980; Crook and others, 1987), tempered by our interpretation of gravity anomalies (McCulloh, 1957; Chapman and Chase, 1979).

Four lines of surface and subsurface evidence, the latter three of which are graphically summarized in figure 9, independently suggest that cumulative left separation is about 13-14 $\mathrm{km}$ : (1) The reconstructed axis of the $>7 \mathrm{Ma}$ Tarzana submarine fan (Sullwold, 1960) is offset about $16 \mathrm{~km}$ (Redin, 1991, fig. 9). However, this amount includes $2.4 \mathrm{~km}$ of left slip on the Benedict Canyon Fault (Hoots, 1931; Weber and others, 1980) that merges with the Santa Monica zone west of our area; it also makes no allowance for possible differential shortening of either adjacent block because of movements on reverse faults or folds. (2) The outcrop belt of Jurassic spotted (cordierite-bearing) Santa Monica Slate and associated schists (Hoots, 1931, plate 16 and p. 88-89) is offset more than $10.2 \mathrm{~km}$ from identical rocks cored in drill hole E (fig. 9, table 4) on the Elysian Park high southeast of the zone (Schoellhamer and Woodford, 1951). (3) The intrusive contact between Cretaceous granodiorite and schistose Santa Monica Formation north of the zone is offset less than $22.5 \mathrm{~km}$ from a presumably correlative subsurface contact southeast of the zone (Dibblee, 1982, p. 111; but also see Wright, 1991, p. 62). (4) The junction of the Verdugo Fault (Luisian and older) with the Raymond Fault is offset more than $13 \mathrm{~km}$ from approximate alignment with the eastern extension of the Sierra Madre Fault, with no allowance for possible postseparation shortening through reverse slip on the latter fault.
A cumulative left-lateral strike separation of 13-14 km for the eastern Santa Monica-Raymond Fault Zone seems an acceptable compromise in view of all constraints.

An interpretation that 60 to $90 \mathrm{~km}$ of left slip accumulated on the Malibu Coast-Santa Monica-Hollywood-Raymond-Sierra Madre zone since onset in middle Miocene time is well entrenched. This interpretation depends on hypothetical extensions of Sespe fluvial strata (Truex, 1976), a hypothetical late Paleocene paleoshoreline and associated strata (Sage, 1973, 1975), and a postulated but unsupported lower Miocene Vaqueros Formation paleoshoreline (Campbell and Yerkes, 1976) from the Santa Ana Mountains north to the San Gabriel Mountains frontal faults. These hypothetical extensions do not exist (McCulloh and others, 2000; this report). The 60 to $90 \mathrm{~km}$ of cumulative left slip is invalid.

Evidence for timing and duration of movement on the Santa Monica-Hollywood-Raymond Fault Zone is straightforward. Erosion from the upthrown block north of the zone influenced basinal deposits as old as 3.7 Ma (Wright, 1991, p. 60, 62). The youngest turbidite sandstones of the Tarzana submarine fan were deposited at about 7.8 Ma (Pierce, 1956, table 1, fig. 6) and the fan axis is offset the same amount (within approximation limits) as basement rock contacts. Left slip must have begun later than 8-7 Ma, much later than the middle Miocene time suggested by Campbell and Yerkes (1976), and long after the 17.5 \pm Ma start of clockwise rotation of the western Transverse Ranges (Luyendyk, 1990; Dickinson, 1996,

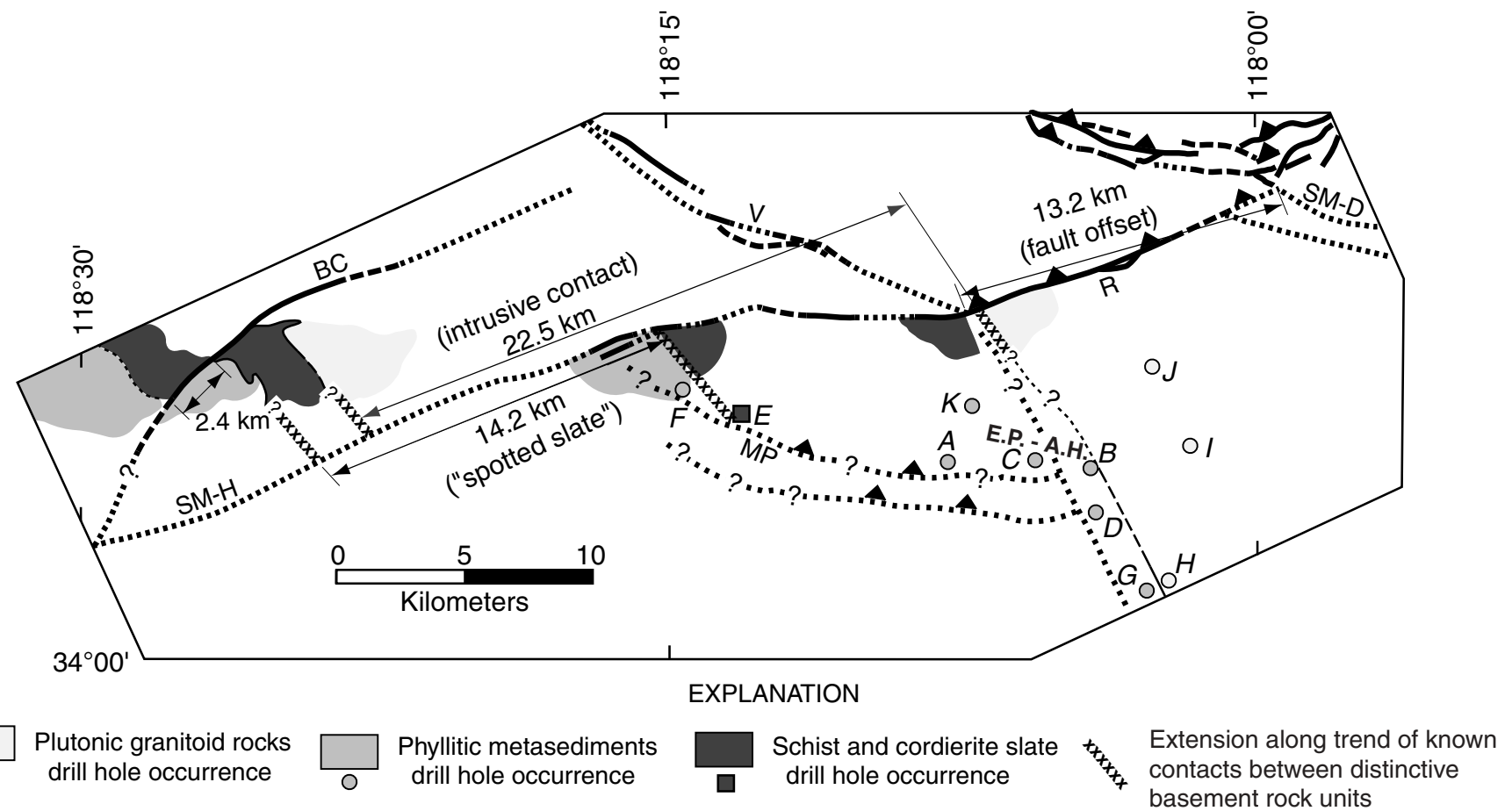

Figure 9.-Approximate outcrop and drill hole geology that supports estimate of 13-14 km of sinistral strike slip on the eastern Santa Monica-Hollywood-Raymond Fault System. Not shown is the offset axis of the Miocene Tarzana (submarine) fan, which testifies to the Neogene age of the offset and supports offset estimates of "6 to 8" miles (Wright, 1987, p. 24) or "10-15 km" (Redin, 1991, p. 250; Wright, 1991, p. 62) without considering the additive effect of $2.4 \mathrm{~km}$ of left strike slip contributed by the Benedict Canyon Fault (Hoots, 1931; Durrell, 1954). For details on labeled drill holes A through $\mathrm{K}$, see table 4 . Fault symbols as in figure 1; see figure 2 for fault labels. 
Table 4. Petroleum exploration drill holes that provide critical control for determination of total left slip on the Raymond Fault (figs. 9, 10) and partial control for configuration of basement rocks (fig. 2).

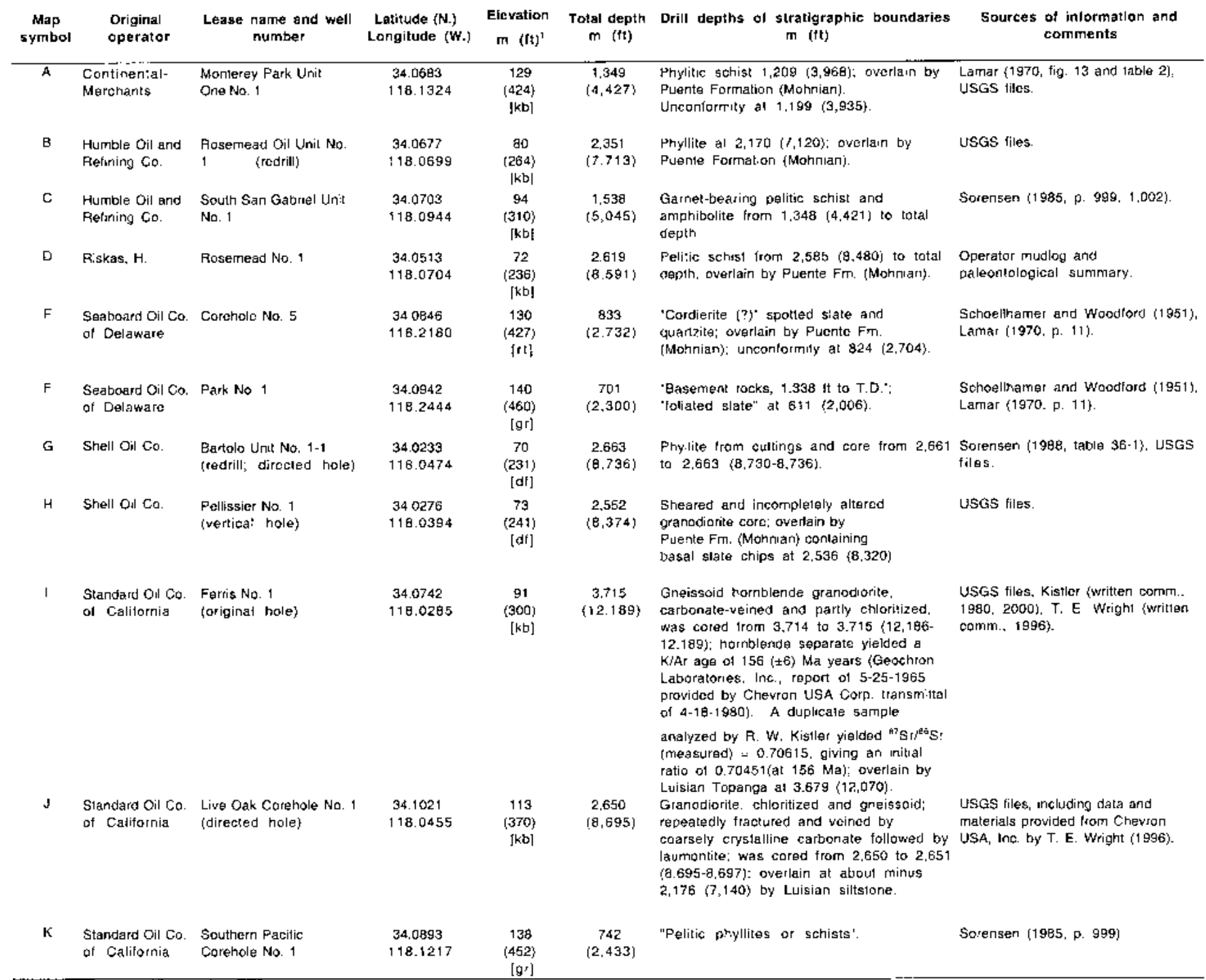

Depth datum: kb. $n_{1}$ df. $g r=k$ kliey bushing. rotary table, derrick lloor. ground level.

fig. 10, table 2). However, left slip clearly began before 3.7 Ma and continues today (Jones and others, 1990). Therefore, at a rotation rate of $5.8^{\circ}$ per m.y., found by Luyendyk (1990, fig. 3) for the entire western Transverse Ranges block, a total clockwise rotation of this southeastern end of the block might be in the range between $20^{\circ}$ and $40^{\circ}$ (assuming that translation and rotation occur together). We return to this point later, but assume conservatively for now that translation and rotation in the study area occurred together and probably only since 4-3 Ma.

\section{San Gabriel-Sierra Madre Zone of Faults}

We suggest that the $13-14 \mathrm{~km}$ of sinistral slip on the Raymond Fault effectively disappears at the junction with the
Sierra Madre zone. Right slip on the Vasquez Creek branch of the San Gabriel-Sierra Madre zone, in part overprinted by reverse slip because of the merge with the Santa Susana break, translates partially to reverse dip slip on the south break of the Clamshell-Sawpit fault complex near the same junction. Left slip (with clockwise rotation) of the region north of the Raymond Fault and southwest of the Vasquez Creek Fault makes room (in plan view) for the isosceles-shaped block bounded by the Vasquez Creek-Sierra Madre, the south break of the Clamshell-Sawpit fault complex, and part of the San Gabriel North Branch zones. The Vasquez Creek Fault is, in effect, a tear fault; the south break Clamshell-Sawpit reverse fault is the same shear; and the segment of the Sierra Madre zone that connects the Vasquez Creek Fault and the south break Clamshell-Sawpit fault might better be viewed as the Vasquez Creek Fault, a connector between the Sierra Madre 


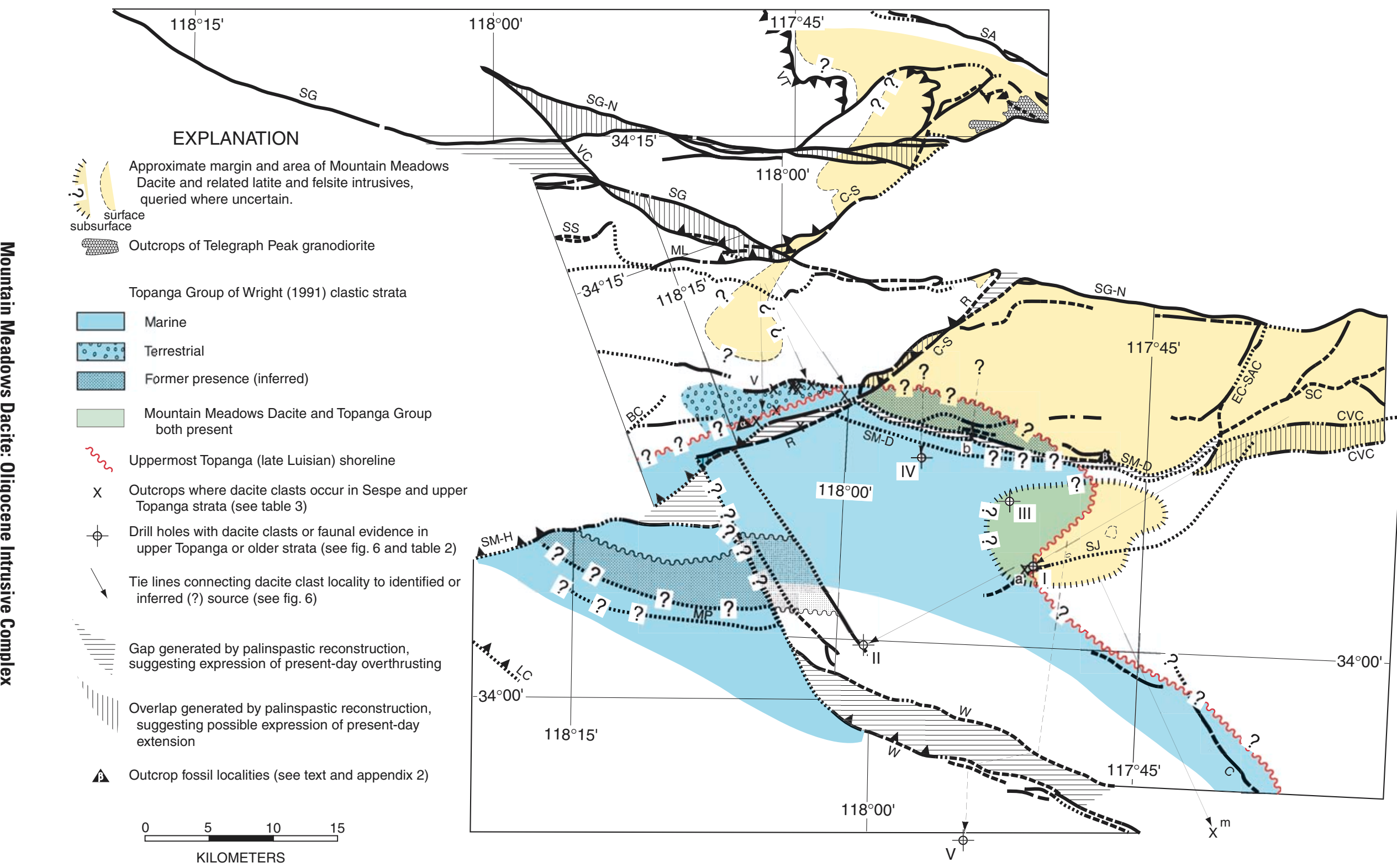

Figure 10.-Palinspastically reconstructed fault blocks, faults, Mountain Meadows Dacite distribution, and Topanga and Sespe Formation dacite clasts with tielines to sources that are known (solid lines) or inferred (dashed lines). The palinspastically rearranged latest Topanga shoreline is also shown. Fault symbols as in figure 1; see figure 2 for fault labels. 
and the Santa Susana reverse faults (although reverse dip slip east of the merge with the Santa Susana overprints right slip). The north break of the Clamshell-Sawpit fault complex is a reverse fault that is the offset eastern continuation of the Mount Lukens reverse fault, broken and dextrally offset by the
Vasquez Creek-south break Clamshell-Sawpit tear and thrust. In this construct none of the left slip on the Raymond Fault passes onto the Sierra Madre Fault Zone east of the junction. Farther east the latter is characterized by reverse dip slip at least as far east as its junction with the Evey Canyon-San
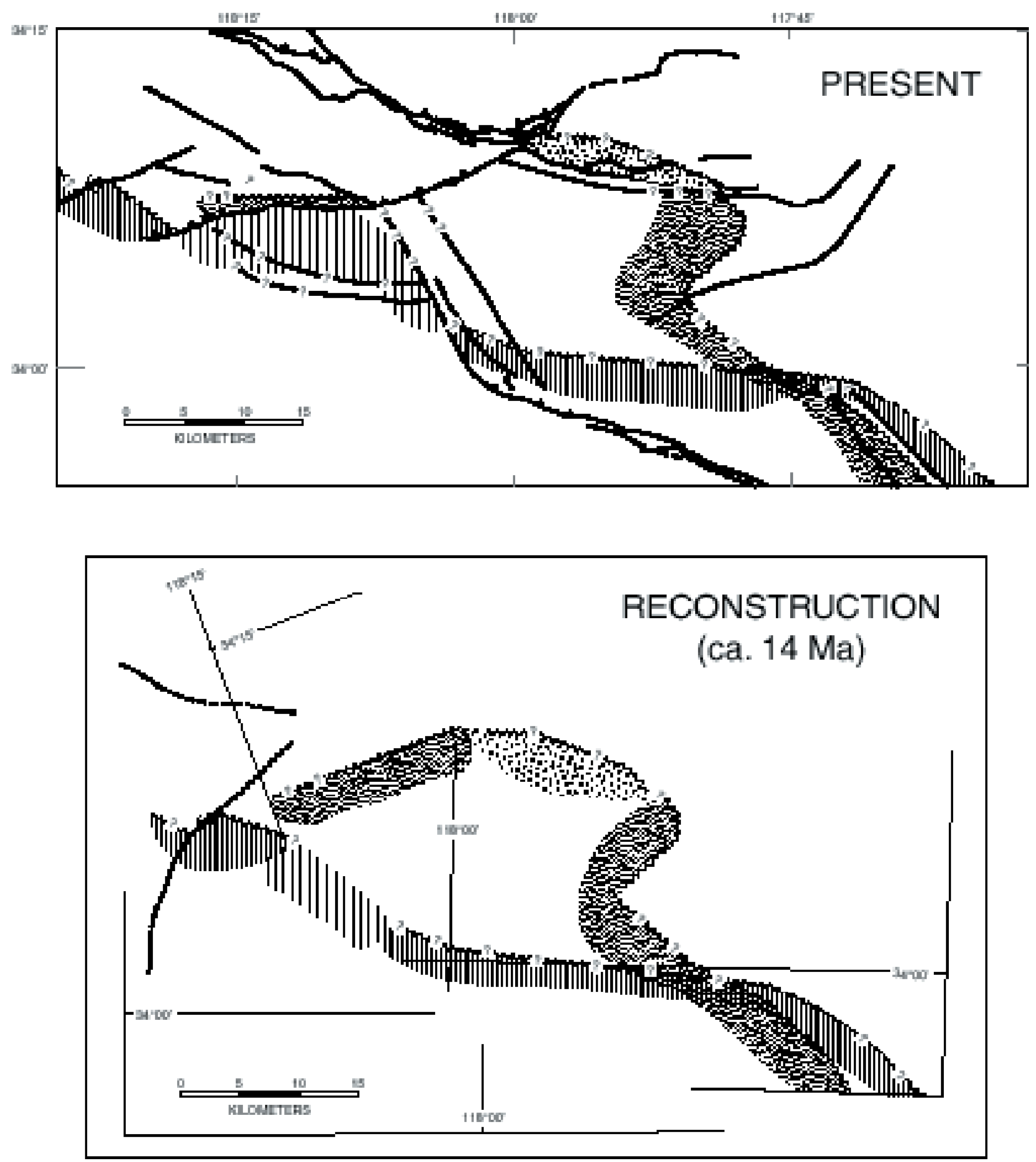

EXPLANATION

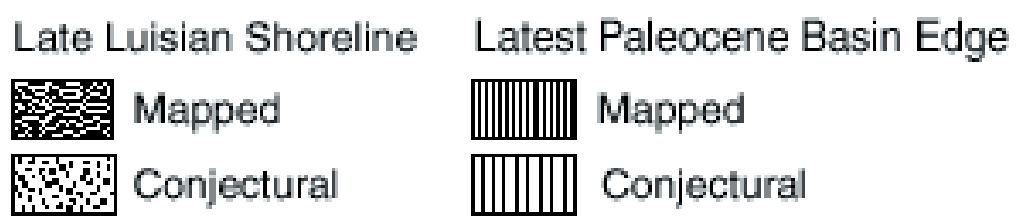

Figure 11.-Northern Los Angeles Basin strandline deposits for the uppermost Topanga Formation (late Luisian) and Paleogene basin-edge deposits (with inferred connections) before and after palinspastic reconstruction according to the model in this report. Fault symbols as in figure 1; see figure 2 for fault labels. 
Antonio fault complex, with continuation on the Cucamonga Fault farther east. Oblique reverse right slip on the south break of the Clamshell-Sawpit fault complex hypothetically merges to the northeast with the eastern part of the San Gabriel North Branch Fault in our model. [ Note: Dibblee (1998) assigns the names North Sawpit fault and South Sawpit fault to what are here termed the north and south breaks of the Clamshell-Sawpit fault complex.]

\section{Reconstruction}

Our model (fig. 10) derives from (1) the 13-14 km of left slip on the eastern Santa Monica-Hollywood-Raymond Fault Zone, (2) the late onset ( $<7$ and $>3.7 \mathrm{Ma}$ ) and rapid rate of strike slip on the zone, (3) clockwise rotation of the region north of the zone during translation, (4) coordinated simultaneous right slip on the Vasquez Creek Fault (and San Gabriel Fault main strand), (5) correlation of the Mount Lukens Fault with the north branch of the Clamshell-Sawpit fault complex that is right-laterally displaced about $13 \mathrm{~km}$ by the Vasquez Creek Fault, and (6) about $9 \mathrm{~km}$ of right slip on the Whittier fault.

Prior to initial slip on the Vasquez Creek-Sawpit Canyon tear and thrust, the isosceles-shaped block was part of the region north of the San Gabriel (main) Fault. Palinspastic restoration to its pre-Vasquez Creek Fault position, shown approximately in figure 10, realigns the western edge of the field of dacite intrusives across the San Gabriel North Branch with the appendage south of the Mount Lukens Fault and southwest of the Vasquez Creek Fault. By itself, this realignment is support for the reconstruction. All upper Topanga dacite-latite clasts also remain tied to unique sources despite back-rotation of the eastern Santa Monica Mountains-Verdugo Mountains and backslip on the Raymond Fault. The proposed reconstruction also provides a credible reorganized alignment of the late Luisian shoreline (fig. 11).

A substantial body of other observational facts is consistent with this reconstruction. The steeply dipping Vasquez Creek Fault merges with minimal change with the steeply dipping segment of the Sierra Madre Fault Zone west of its junction with the Raymond Fault (Morton, 1973, p. 16-17); we view the Vasquez Creek and western Sierra Madre as strands of the same fault. Conversely, the gently north-dipping Mount Lukens Fault (Smith, 1986) is like the moderately northwestdipping north break of the Clamshell-Sawpit fault complex (Morton, 1973; Dibblee, 1998); in our model the latter is the offset continuation of the former.

The 1991 Sierra Madre earthquake showed that slip on the Clamshell-Sawpit zone is now reverse and nearly dip slip (Hauksson, 1994). Seismologic evidence indicates left slip on the Raymond Fault parallel to the fault strike (Jones and others, 1990). The approximate alignment of these faults in map view hints at affinity, but seismological evidence and our model suggest they are separate faults.

The previously puzzling absence of evidence for large dextral displacement along the south flank of the San Gabriel Mountains east of the Raymond Fault junction, especially because of the "continuous distribution of the 15-m.y.-old Glendora Volcanics across the projected fault path" (Powell and Weldon, 1992, p. 457), is now readily understood. Right slip on the Vasquez Creek-Sierra Madre tear fault converts substantially to dip slip on the (south) Clamshell-Sawpit zone and does not continue eastward beyond the junction with the Raymond Fault.

Backslip of $22 \mathrm{~km}$ on the San Gabriel North Branch Fault is required to realign the mapped western edges of the field of dacite intrusives across the fault. This amount matches reasonably closely the " $20 \mathrm{~km}$ " of right-lateral strike slip indicated by the "nearly vertical contact between the Mendenhall Gneiss and Mount Lowe Granodiorite"(Dillon and Ehlig, 1993, p. 210-211, fig. 5). "A right slip of 7 miles [11 km] would be a minimum displacement along the southern branch of the [San Gabriel or Vasquez Creek] fault" (Ehlig, 1975a, p. 14) on the basis of clast compositional uniqueness and possible clast-source ties observed in gravel beds in Mio-Pliocene marine sandstones in Gold Canyon (Oakshott, 1958, p. 77) along the San Gabriel Fault main break. This approaches our 12-13 $\mathrm{km}$ value.

Kinematically the linkage of right slip on the Vasquez Creek-Sierra Madre tear fault with reverse dip slip on the Clamshell-Sawpit zone is analogous to the way that "rightlateral strands of the San Jacinto Fault curve westward and southwestward into the [southeastern] San Gabriel Mountains and transform into east- to northeast-trending northdipping faults that have reverse left-slip displacement" (Matti and Morton, 1993, p. 114).

Our palinspastic reconstruction assumes simplistically that all fault blocks are rigid, all movements are confined to the major faults, and all movements are in a level plane. We recognize that these assumptions are only partly valid. Gaps between fault blocks of our map suggest regions of compressive overriding along boundaries. Overlaps along junctions suggest regions where tensional separation might have occurred since our presumed starting arrangement (fig. 10). The poor fit between the isosceles-shaped block of figure 10 and its surroundings is in part because we have made no effort to incorporate internal deformations associated with insufficiently mapped second-order faults and likely differential tiltings.

The distribution of Oligocene dacite-latite intrusives in the southwestern San Gabriel Mountains, San Rafael Hills, and Verdugo Mountains suggests continuity across the eastern Santa Susana Fault Zone (Smith, 1986; Crook and others, 1987) (fig. 5). In turn this suggests that cumulative strike separation along that fault zone is negligible, although dip separation might be appreciable.

Note that we have made no effort to reconstruct the southeastern San Gabriel Mountains, because our work on the principal bounding faults there (Cucamonga, Evey Canyon, San Antonio Canyon, Stoddard Canyon, Icehouse Canyon, and others) is insufficient to deal with the challenges. However, the present-day north-dipping reverse Cucamonga Fault probably was a south-dipping normal fault that had substantial topographic relief and was active as early 
as about 16 Ma. It likely continued west along the Sierra Madre Fault Zone trace to the present junction with the Raymond Fault, where it joined the subsequently separated and rotated Verdugo Fault.

We also leave unanswered the question of what rocks once filled the large blank area of our reconstruction east of the Clamshell-Sawpit fault complex and north of the Sierra Madre zone. Preliminary work suggests that outcrops between the San Jacinto and San Andreas Fault Zones eastsoutheast of our area may supply the answer.

\section{Rotations from Paleomagnetic Measurements}

Paleomagnetic declination data and interpretations indicate that the entire western Transverse Ranges province underwent clockwise rotation of $78^{\circ}$ to $95^{\circ}$ since early Miocene (Hornafius and others, 1986; Liddicoat, 1990). However, partial and fragmentary data suggest that rotation of the eastern Santa Monica Mountains, the northern San Fernando Valley and the eastern Ventura Basin was more limited, probably at lower rotational rates, and less regular than for the province as a whole (Hornafius and others, 1986, fig. 8 and table A; Liddicoat, 1992; Levi and Yeats, 1993). This eastern end of the province, close to the rotational hub, behaved in a fragmented fashion; different fault blocks rotated at different rates (or not at all) and for different lengths of time. Thus, for example, the young Saugus Formation $(<2.3 \mathrm{Ma})$ of the eastern Ventura Basin north of the Santa Susana Fault records about $30^{\circ}$ of clockwise rotation, whereas the same strata south of the fault did not rotate during the same time interval (Levi and Yeats, 1993, p. 700-701). Similarly, dolomite beds of estimated age 11.5 $\pm 1.2 \mathrm{Ma}$ in the eastern Santa Monica Mountains, west of the Benedict Canyon Fault, record only about $37.5^{\circ}$ of rotation (Hornafius and others., 1986, fig. 8 and p. 1481). This suggests that the $20^{\circ}$ of rotation we incorporate for the more easterly portion of the block north of the HollywoodRaymond block is acceptably consistent with those more westerly observations.

Paleomagnetic declination data pertinent to the San Gabriel Mountains sensu strictu come only from outside our map area, northwest of most of the basement rock outcrops, and northeast of the San Gabriel Fault main break. Two episodes of opposing rotation were interpreted for that subregion from less than ideally constrained data: $53^{\circ} \pm 32^{\circ}$ of clockwise rotation between about $21 \mathrm{Ma}$ and $15 \mathrm{Ma}$, followed by $16^{\circ} \pm 30^{\circ}$ of apparent counterclockwise rotation since 11-10 Ma (Hornafius and others, 1986, fig. 7). These findings imply that the strike of the (future) northwestern San Gabriel Fault must have been nearly east-west until between 18 and $11 \mathrm{Ma}$. Our reconstruction assumes that the strike of the eastern San Gabriel north branch (which is now about east-west) has not rotated. This is consistent with the observational fragment that "paleomagnetic data collected from both formations [Glendora Volcanics and El Modena Volcanics of the eastern Los Angeles Basin] do not show a rotation" (J. C. Liddicoat in Earth Sciences Board, 1988, p. 246). Cretaceous strata southeast of our area show negligible rotation (Fry and others, 1985). Our reconstruction assumes that evidence for rotations from the region northwest of the central San Gabriel Mountains does not pertain directly to the study area.

\section{Discussion and Conclusions}

We have mapped the areal extent, both surface and subsurface, of western limits of the late Oligocene Mountain Meadows Dacite intrusive complex, Telegraph Peak granodiorite, and consanguinous felsites and latites, where they occur in the San Gabriel Mountains and the adjacent northeastern Los Angeles Basin. This distinctive suite transects major tectonic boundaries and ties together the northern Los Angeles Basin, the central San Gabriel Mountains (both north and south of the San Gabriel Fault north branch), the southeastern San Gabriel Mountains (east of the San Antonio Fault), the northeastern San Gabriel Mountains (north of the Vincent Thrust), and the southwestern San Gabriel Mountains, San Rafael Hills, and Verdugo Mountains (southwest of the Mount Lukens and Vasquez Creek Fault Zones).

A systematic search was made for dacite, felsite, or latite clasts redeposited in $\geq 14$ Ma strata of the Los Angeles Basin succession (Topanga Group or older). Such clasts were transported and deposited at multiple sites during the times when Sespe beds and strata of the Topanga Group were accumulating along the northeast and northern Los Angeles Basin margin. Elevation of the ancestral San Gabriel Mountains with concomitant erosion began probably as early as $16 \mathrm{Ma}$. Uplift occurred on faults (probably normal) that extended eastward from the western Verdugo Fault Zone, along the Sierra Madre zone east of its junction with the Raymond Fault to include the Cucamonga Fault Zone at the southeast end of the range. At the same time, bathyal deposits accumulated in the Los Angeles Basin bight or seaway beneath open marine waters that supported nutrientrich upwelling close to the fault-controlled shoreline.

Even earlier erosion and transport of Mountain Meadows Dacite, prior to eruption of Glendora Volcanics and probably as early as $18 \mathrm{Ma}$, deposited dacite clasts in fluvial deposits of the Sespe Formation now found as outcrops and subsurface remnants in the Whittier and Puente Hills. A lower Miocene eroding topographic high with southwest- to southeast-sloping fluviatile distributary systems is implied.

Even without palinspastic reconstruction, ties between dacite-latite sources and derived clasts in Topanga strata illuminate the petrologic connection of the complex junction of the Los Angeles Basin with the westernmost extension of the Peninsular Ranges and the San Gabriel Mountains part of the Transverse Ranges. Palinspastic adjustments reinforce the connection, improve understanding of the movement history of faults of the San Gabriel Fault System, and lead to a new and simple model of latest middle Miocene paleogeography.

Timing of major depositional and structural events that bridge across boundaries separating the Los Angeles Basin from the northwestern Peninsular Ranges Province and the Transverse Ranges are summarized by figure 12. All faults 
considered in our reconstruction are shown (fig. 10), along with timing of Neogene igneous events and provincial benthic foraminiferal zonal divisions (Blake, 1991).

Our palinspastic reconstruction furnishes a new gauge of the total right-lateral strike slip on the San Gabriel main strand (mostly northwest of our area), its North Branch, and its southern branch, the Vasquez Creek Fault. Right-lateral strike slip separation of 20-22 km on the San Gabriel North Branch Fault (east of the junction with the Vasquez Creek branch) is beyond dispute (Ehlig, 1975b, 1981; Dillon and Ehlig, 1993; this study). Right-lateral strike slip separation of the north break of the Clamshell-Sawpit zone from the Mount Lukens Fault by the Vasquez Creek Fault is about $13 \mathrm{~km}$. These separations pass to the northwest onto the main San Gabriel Fault, suggesting a total there of about $34 \mathrm{~km}$ of right slip. This postulated total ignores possible differential shortening along one wall or the other of these several faults and the possibilities that some other branch of the San Gabriel zone absorbed slip, that minor left slip on northeast-striking faults occurred, or that associated vertical deformation affects our estimate. Our 34-km total should be compared with the aggregate of "40 to 45" km supported by Powell (1993, p. 36), or "60 km" (Crowell, 1975; Ehlig and Crowell, 1982; May and others, 1993; Yeats and others, 1994, p. 1058-1060 and fig. 11; Dickinson, 1996, p. 25-26), or "70 km" (Ehlert, 1982).

The Canton Fault in the eastern Ventura Basin (or "southwest edge of [buried] basement ridge" fault of Yeats and others, 1994, fig. 3) was previously proposed as a candidate to accommodate some possibly missing right slip from the main San Gabriel Fault (Powell, 1993, fig. 14 and p. 40) (fig. 1). We see some reasons to correlate the Verdugo Fault of our area with this break. However, we see no evidence that the Verdugo Fault has undergone notable post-Relizian right slip. The "basement ridge" break in the eastern Ventura Basin displays some drill hole characteristics that limit any strike slip to $1-2 \mathrm{~km}$ at most.

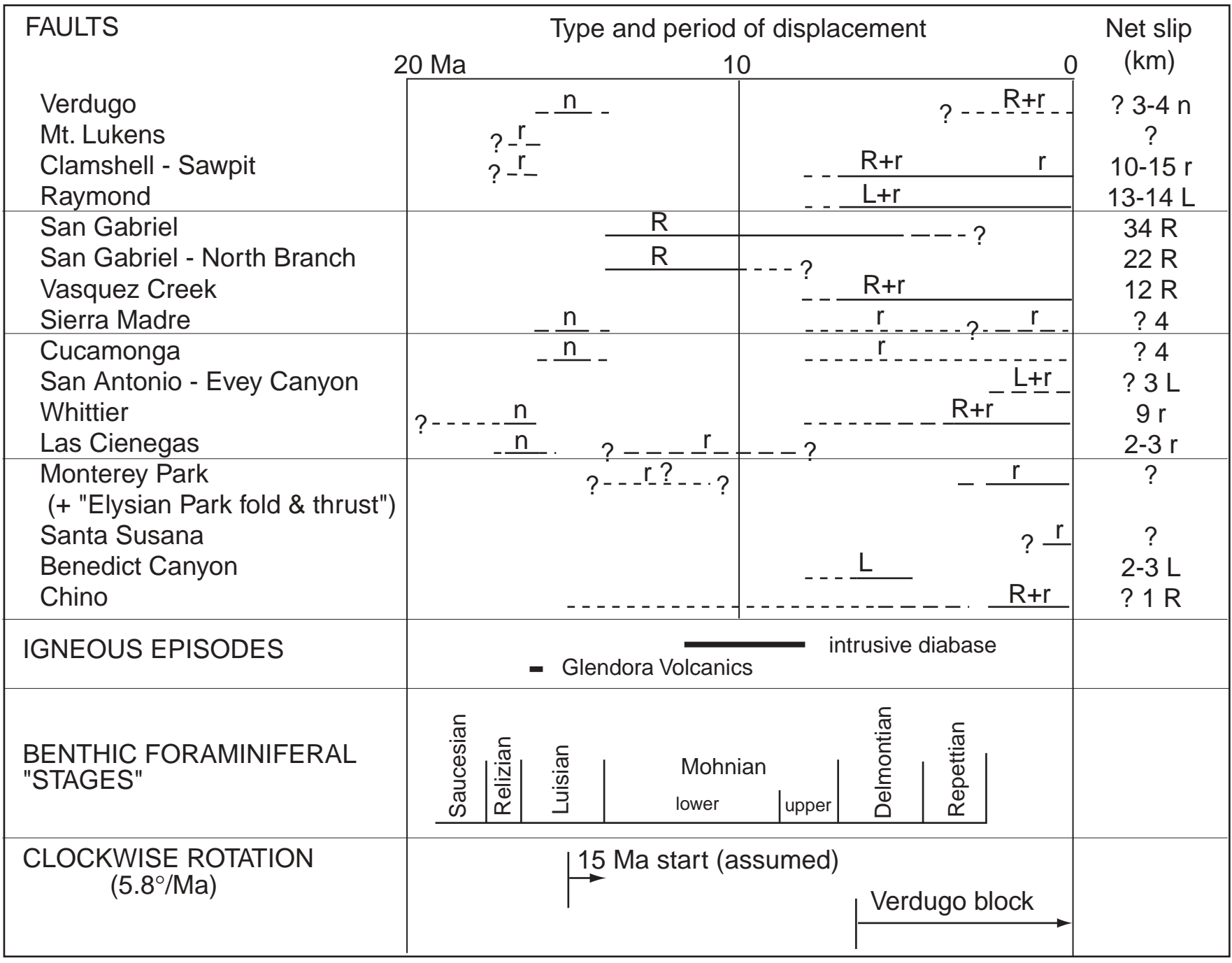

Figure 12.-Chronology of Neogene fault movements, igneous events, and fault-block rotations consistent with the palinspastic reconstruction for this study. Comparison with prior results (table 1) is instructive. " $\mathrm{R}$ " and " $\mathrm{L}$ " indicate right-lateral and left-lateral strike slip, respectively; " $\mathrm{n}$ " and " $\mathrm{r}$ " indicate normal and reverse slip, respectively. 
Minor right slip might have splayed from the Vasquez Creek Fault segment of the Sierra Madre zone onto the eastern segment. However, lack of substantial strike offset of both the Los Angeles Basin Glendora Volcanics and associated marine Puente Formation beds containing foraminifers indicative of an age between 13 and 8.7 Ma (Proctor and others., 1970, p. 7) permits only substantial reverse dip slip. Vertical movements associated with strike slip, for example, the " $* * *$ listric, east-southeast-dipping oblique-slip fault $* * *$ " elucidated by combining reflection seismic and surface geological mapping in the northwestern Ridge Basin (May and others, 1993), could contribute to the balance sheet. However, we believe future investigators will be challenged to reconcile the right-slip difference of 6-11 km between Powell (1993) and this report, and even more so the difference of $26-36 \mathrm{~km}$ between some earlier estimates and this report.

Many palinspastic reconstructions have sought to explain the structural, stratigraphic, and paleogeographic evolution and complexities in our study area. Thirteen deserve attention because they contribute relevant data, valuable or original concepts, ingenious approaches, or are important historical landmarks (Woodburne, 1975; Truex, 1976; Yeats, 1976; Hornafius and others, 1986; Wright, 1991, fig. 36; Powell and Weldon, 1992, fig. 4C; Crouch and Suppe, 1993, fig. 4; Dillon and Ehlig, 1993, fig. 5; Powell, 1993; Matti and Morton, 1993, figs. 7A-K; Yeats and others, 1994; Fritsche, 1998, figs. 2, 3, 8; Ingersoll and Rumelhart, 1999). Two of these prior reconstructions (Powell and Weldon, 1992, or Powell, 1993; Yeats and others, 1994) approach closest to a partial match with ours, even though neither completely overlaps our study area. Our maps of the areal distribution of Mountain Meadows Dacite sources and clasts and of the restricted extent of Sespe and older pre-Topanga sedimentary rocks can be used to test these or other reconstructions.

A partly independent test of our reconstruction is how well it pieces together fragmentary and tectonically dismembered remnants of ancient depositional systems into coherent paleogeographic and paleoceanographic constructs. We have shown how backslip of the Raymond Fault (with accompanying back-rotation) reconnects the marine embayment southwest of the Verdugo Fault with the Luisian marine depositional area of the San Gabriel Valley and San Jose Hills. The Luisian shoreline crudely followed the fault scarp boundary that separated the eroding ancestral Verdugo Mountains and western and central San Gabriel Mountains from the broad deep seaway that extended northward from the main Los Angeles Basin and as far east as the paleoshoreline mapped through the eastern San Jose Hills by Woodford and others (1946) (fig. 6). Nannos that thrived in open marine and probably upwelling environments near the steeply sloping northern and northeastern basin edges are associated with upper bathyal benthic foraminifers (fig. 6 , drill hole IV, localities $\alpha$ and $\beta$ ). Distances to shore of perhaps at least $4-5 \mathrm{~km}$ are suggested by the presence of nannos. Upper bathyal benthic foraminifers suggest great local bathymetric relief, an interpretation consistent with associated coarse breccias and boulder conglomerates (Lamar, 1970; Dibblee, 1989).
Moving back in time to latest Paleocene (about $55 \mathrm{Ma}$ ), our reconstruction allows us to piece together a few remaining surface and subsurface fragments of the depositional edge of a sequence of interbedded shallow marine and fluviatile strata. A reconstructed partial depositional basin margin (McCulloh and others, 2000) was questionably extended westward from scattered subsurface control in the eastern Puente Hills to the Whittier Fault not far northwest of the intersection of $34^{\circ} \mathrm{N}$. and $118^{\circ} \mathrm{W}$. Thin remnants of the correlative sequence crop out locally in the eastern Santa Monica Mountains (Colburn and Novak, 1989, figs. 8, 9) and define a transition from nonmarine to interbedded marine and continental depositional settings. Our study provides the first basis for projecting a connection between these Santa Monica Mountains basin margin deposits and those that occur only in wells in the eastern Puente Hills. These two areas of fragmented basin margin remnants connect in a plausible manner in our reconstruction (fig. 11)

A comprehensive and thorough tectonic reconstruction for the southern California region (ca. $20 \mathrm{Ma}$ ) was proposed in an impressively inclusive and well documented study of the evolution of the entire San Andreas Fault System (Powell, 1993). We have not determined in what ways our results augment or conflict with Powell's conclusions about the entire system. We instead relate our results to the opening of the Los Angeles Basin and the clockwise rotation of the western Transverse Ranges. Our conclusion of limited right slip on the San Gabriel Fault System, as an older subset of the San Andreas Fault System, ought to affect understanding of the entire region. Our results should also increase interest in the incorporation of fault-block domain rotation into future models of the entire system, particularly as new data illuminate the importance of three-dimensional block rotations (for example, Scotti and Nur, 1990).

The relatively late onset of left strike slip on the Raymond Fault and coupled clockwise rotation of the eastern Santa Monica-Verdugo block raise several important questions: (1) Where is the hub or rotation axis about which this easternmost part of the western Transverse Ranges turned? (2) Why was the onset of rotation so late relative to the much earlier beginning of rotation for the great bulk of the transrotating beam farther southwest (Hornafius and others, 1986; Luyendyk, 1990; Nicholson and others, 1994; Dickinson, 1996)? (3) What connection and significance is there between the Los Angeles Basin opening and the late onset of transrotation of this easternmost part of the entire transrotational region? (4) Is there special temporal significance to the growing mass of evidence for blind thrusts and earthquakes on cryptic structures (Hauksson, 1990, p. 15369)?

Our work leads toward answers to some of these questions and suggests promising routes toward answers to others. One of the answers may be in hand. Transrotation of the western Transverse Ranges beam has probably been progressive, from southwest to north, and segmented both areally and temporally, with the eastern segments of the beam the last to participate. The rotational hub of the youngest of the transrotating blocks almost certainly shifted as the several involved fault blocks moved (three dimensionally). One approximate 
pivot point, an artifact of the figure 10 reconstruction, is located at present day latitude $34.333^{\circ} \mathrm{N}$. and longitude $118.039^{\circ} \mathrm{W}$., with a $5-\mathrm{km}$-diameter circle of uncertainty.

Our work implies much about vertical tectonic movements, but little has been stated explicitly because quantitative information is meager. The 1991 Sierra Madre earthquake $\left(M_{L}=5.8\right)$ raised the southern part of the San Gabriel Mountains directly above the hypocenter by less than $1 \mathrm{~cm}$ (Hauksson, 1994, p. 1071) and was clearly associated with reverse dip slip on the Clamshell-Sawpit fault complex. The southern edge of the western San Gabriel Mountains (west of our study area) rose by as much as 2 meters during the 1971 San Fernando earthquake $\left(M_{L}=6.4\right)$, which ruptured the ground surface and occurred on the north-northeast-dipping Santa Susana thrust fault (Allen and others, 1975). Longer term uplift of the southern margin of the range is indicated by widely distributed late Tertiary and Quaternary marine strata in the westernmost part of our map area that are now folded, faulted, and uplifted to elevations well above present sea level. A special example is the Mio-Pliocene "fossiliferous marine" pebbly sandstone south of the San Gabriel Fault Zone at the western edge of our study area (Oakshott, 1958, p. 77) that presently is about 670 to $790 \mathrm{~m}(2,200-2,600 \mathrm{ft})$ above sea level. These marine sandstones testify to the recency, duration, and amount of uplift of this part of the mountains. Other evidence of vertical movements is either less quantitative or less amenable to unique interpretion (Cummings and others, 1982). Future research will doubtless lead to improved understanding and better palinspastic models. A comprehensive study of the thermal history of the Mountain Meadows intrusive field and its different parts is one particularly inviting avenue for such research.

\section{References Cited}

Alf, R. M., 1948, A mylonite belt in the southeastern San Gabriel Mountains, California: Geological Society of America Bulletin, v. 59, p. 1101-1120.

Allen, C. R., Hanks, T. C., and Whitcomb, J. H., 1975, Seismological studies of the San Fernando earthquake and their tectonic implications, in Oakeshott, G. E., ed., San Fernando, California, earthquake of 9 February, 1971: California Division of Mines and Geology Bulletin 196, p. 257-262.

Atwater, T., and Stock, J., 1998, Pacific-North America plate tectonics of the Neogene southwestern United States: an update: International Geology Review, v. 40, p. 375-402.

Baird, A. K., Morton, D. M., Woodford, A. O., and Baird, K. W., 1974, Transverse Ranges province: a unique structural-petrochemical belt across the San Andreas fault system: Geological Society of America Bulletin, v. 85 , p. $163-174$.

Barbat, W., F., 1958, The Los Angeles Basin area, California, in Weeks, L. G., ed., Habitat of Oil; a symposium: Tulsa, Oklahoma, American Association of Petroleum Geologists, p. 62-77.
Barth, A. P., Wooden, J. L., Tosdal, R. M., Morrison, J., Dawson, D. L., and Hernly, B. M., 1995, Origin of gneisses in the aureole of the San Gabriel anorthosite complex and implications for the Proterozoic crustal evolution of southern California: Tectonics, v. 14, p. 736-752.

Bellemin, G. J., 1940, Petrology of Whittier conglomerates, southern California: American Association of Petroleum Geologists Bulletin, v. 24, p. 649-671.

Berger, W. H., 1973, Deep-sea carbonates; evidence for a coccolith lysocline: Deep-Sea Research and Oceanographic Abstracts, v. 20, p. 917-921.

Berggren, W. A., Kent, D. V., Flynn, J. J., and van Couvering, J. A., 1985, Cenozoic geochronology: Geological Society of America Bulletin, v. 96, p. 1407-1418.

Berggren, W. A., Kent, D. V., Swisher, C. C. III, and Aubry, M.-P., 1995, A revised Cenozoic geochronology and chronostratigraphy, in Berggren W. A., Kent, D. V., Aubry, M.-P., and Hardenbol, J., eds., Geochronology, time scales and global stratigraphic correlation: Society for Sedimentary Geology Special Publication No. 54, p. 129-212.

Blake, G. H., 1991, Review of the Neogene biostratigraphy and stratigraphy of the Los Angeles basin and implications for basin evolution, in Biddle, K. T., ed., Active margin basins: American Association of Petroleum Geologists Memoir 52, p. 135-184.

Bohannon, R. G., and Geist, E., 1998, Upper crustal structure and Neogene tectonic development of the California Continental Borderland: Geological Society of America Bulletin, v. 110, p. 779-800.

Bukry, D., 1981, Pacific Coast coccolith stratigraphy between Point Conception and Cabo Corrientes, Deep Sea Drillling Project Leg 63: Initial Reports of the Deep Sea Drilling Project, 63, p. 445-471.

Cachao, M., and Moita, M. T., 2000, Coccolithus pelagicus, a productivity proxy related to moderate fronts off western Iberia: Marine Micropaleontology, v. 39, p. 131-155.

Campbell, R. H., and Yerkes, R. F., 1976, Cenozoic evolution of the Los Angeles basin area - relation to plate tectonics, in Howell, D. G., ed., Aspects of the geologic history of the California Continental Borderland: Pacific Section, American Association of Petroleum Geologists Miscellaneous Publication 24, p. 541-558.

Castro, M. J., 1975, Mahala field, in Truex, J. N., ed., A tour of the oil fields of the Whittier fault zone, Los Angeles basin, California: Pacific Sections, American Association of Petroleum Geologists-Society of Exploration Geophysicists-Society of Economic Paleontologists and Mineralogists Joint Annual Field Trip, April 26, 1975, p. 73-76.

Chai, Y., and Hinze, W. J., 1988, Gravity inversion of an interface above which the density contrast varies exponentially with depth: Geophysics, v. 53, p. 837-845.

Chapman, R. H., and Chase, G. W., 1979, Geophysical investigations of the Santa Monica-Raymond fault zone, Los Angeles County, California: California Division 
of Mines and Geology Open-File Report 79-16, p. E-1 to E-30.

Colburn, I. P., 1973, Stratigraphic relations of the southern California Cretaceous strata, in Colburn, I. P., and Fritsche, A. E., eds., Cretaceous stratigraphy of the Santa Monica Mountains and Simi Hills: Pacific Section, Society of Exploration Paleontologists and Mineralogists, Fall Field Trip Guidebook, p. 45-73.

Colburn, I. P., and Novak, G. A., 1989, Paleocene conglomerates of the Santa Monica Mountains, California: petrology, stratigraphy, and environments of deposition: in Colburn, I. P., Abbott, P. L., and Minch, J., eds., Conglomerates in basin analysis: a symposium dedicated to A. O. Woodford: Pacific Section, Society of Economic Paleontologists and Mineralogists, book 62, p. 227-253.

Crook, R., Jr., Allen, C. R., Kamb, B., Payne, C. M., and Proctor, R. J., 1987, Quaternary geology and seismic hazard of the Sierra Madre and associated faults, western San Gabriel Mountains, in Recent reverse faulting in the Transverse Ranges, California: U. S. Geological Survey Professional Paper 1339, p. 27-64.

Crouch, J. K., and Suppe, J., 1993, Late Cenozoic tectonic evolution of the Los Angeles basin and inner California Borderland: a model for core complex-like crustal extension: Geological Society of America Bulletin, v. 105, p. 1415-1434.

Crowell, J. C., 1974, Origin of late Cenozoic basins in southern California, in Dickinson, W. R., ed., Tectonics and sedimentation: Society of Economic Paleontologists and Mineralogists, Special Publication No. 22, p. 190-204.

Crowell, J. C., 1975, The San Gabriel fault and Ridge basin, southern California, in Crowell, J. C., ed., San Andreas fault in southern California: California Division of Mines and Geology Special Report 118, p. 208-219.

Cummings, D., Weiss, J., and Haines, E. L., 1982, Cretaceous and Miocene fission track retention ages from Precambrian rocks and thermal history of the western San Gabriel Mountains, southern California, in Fife, D. L., and Minch, J. A., eds., Geology and mineral wealth of the California Transverse Ranges: Santa Ana, California, South Coast Geological Society, Inc., Annual Symposium and Guidebook, Number 10, p. 297-306.

Daviess, S. N., and Woodford, A. O., 1949, Geology of the northwestern Puente Hills, Los Angeles County, California: U. S. Geological Survey Oil and Gas Investigations Preliminary Map 83.

Davis, T. L., Namson, J., and Yerkes, R. F., 1989, A cross section of the Los Angeles area: seismically active fold and thrust belt, the 1987 Whittier narrows earthquake, and earthquake hazard: Journal of Geophysical Research, v. 94, n. B7, p. 9644-9664.

Dibblee, T. W., Jr., 1982, Geology of the Santa Monica Mountains and Simi Hills, southern California, in Fife, D. L., and Minch, J. A., eds., Geology and mineral wealth of the California Transverse Ranges: Santa Ana, California, South Coast Geological Society, Inc., Annual Symposium and Guidebook, Number 10, p. 94-130.

Dibblee, T. W., Jr., 1989, Mid-Tertiary conglomerates and sandstones on the margins of the Ventura and Los Angeles basins and their tectonic significance, in Colburn, I. P., Abbott, P. L., and Minch, J., eds., Conglomerates in basin analysis: a symposium dedicated to A. O. Woodford: Society of Exploration Paleontologists and Mineralogists, Pacific Section, book 62, p. 207-226.

Dibblee, T. W., Jr., 1998, Geologic map of the Mt. Wilson and Azusa Quadrangles: Dibblee Geological Foundation Map \#DF-67, 1:24,000 scale.

Dickinson, W. R., 1996, Kinematics of transrotational tectonism in the California Transverse Ranges and its contribution to cumulative slip along the San Andreas transform fault system: Geological Society of America Special Paper 305, 46 p.

Dillon J. T., and Ehlig, P. L., 1993, Displacement on the southern San Andreas fault, in Powell, R. E., Weldon, R.J., II, and Matti, J. C., eds., The San Andreas fault system: Displacement, palinspastic reconstruction, and geologic evolution: Geological Society of America Memoir 178, p. 199-216.

Dolan, J. F., Sieh, K., Rockwell, T. K., Guptil, P., and Miller, G., 1997, Active tectonics, paleoseismology, and seismic hazards of the Hollywood fault, northern Los Angeles basin, California: Geological Society of America Bulletin, v. 109, p. 1595-1616.

Dolan, J. F., Sieh, K., and Rockwell, T. K., 2000, Late Quaternary activity and seismic potential of the Santa Monica fault system, Los Angeles, California: Geological Society of America Bulletin, v. 112, p. 1559-1581.

Durham, D. L., and Yerkes, R. F., 1964, Geology and oil resources of the eastern Puente Hills area, southern California: U. S. Geological Survey Professional Paper 420-B, 62 p.

Durrell, C., 1954, Geology of the Santa Monica Mountains, Los Angeles and Ventura counties, in Jahns, R. H., ed., Geology of southern California: California Division of Mines and Geology Bulletin 170, map sheet 8.

Earth Sciences Board, 1988, Paleomagnetism of the Zuma Volcanics, Point Dume: California Geology, Los Angeles County, California, v. 41, p. 243-247.

Eaton, G. P., 1958, Miocene volcanic activity in the Los Angeles basin, in A guide to the geology and oil fields of the Los Angeles and Ventura regions: American Association of Petroleum Geologists, Annual Meeting, March 1958, p. 55-58.

Ehlert, K. W., 1982, Basin analysis of the Miocene Mint Canyon Formation, southern California, in Ingersoll, R. V., and Woodburne, M. O., eds., Cenozoic nonmarine deposits of California and Arizona: Los Angeles, Pacific Section, Society of Exploration Paleontologists and Mineralogists, p. 51-64.

Ehlig, P. L., 1973, History, seismicity and engineering geology of the San Gabriel fault, in Moran, D. E., Slosson, J. E., Stone, R. O., and Yelverton, C. A., eds., Geology, Seismicity, and Environmental Impact: Los Angeles, California, Association of Engineering Geologists Special Publication, p. 247-251.

Ehlig, P. L., 1975a, Geologic framework of the San Gabriel 
Mountains, in Oakeshott, G. B., ed., San Fernando, California, Earthquake of 9 February 1971: California Division of Mines and Geology Bulletin 196, p. 7-18.

Ehlig, P. L. 1975b, Basement rocks of the San Gabriel Mountains, south of the San Andreas fault, southern California, in Crowell, J. C., ed., San Andreas fault in southern California: California Division of Mines and Geology Special Report 118, p. 177-186.

Ehlig, P. L., 1981, Origin and tectonic history of the basement terrane of the San Gabriel Mountains, central Transverse Ranges, in Ernst, W. G., ed., Geotectonic developments of California (Rubey Volume 1): Englewood Cliffs, New Jersey, Prentice-Hall, p. 253-283.

Ehlig, P. L., and Crowell, J. C., 1982, Mendenhall Gneiss and anorthosite-related rocks bordering Ridge basin, southern California, in Crowell, J. C., and Link, M. H., eds., Geologic history of Ridge basin, southern California: Pacific Section, Society of Economic Paleontologists and Mineralogists, p. 199-202.

Evans, J. G., 1982, Geology of the Sheep Mountain Wilderness Study Area and the Cucamonga Wilderness and additions, Los Angeles and San Bernardino Counties, California: U. S. Geological Survey Bulletin 1506-A, p. 1-28.

Fritsche, A. E., 1998, Miocene paleogeography of southwestern California and its implications regarding basin terminology: International Geology Review, v. 40, p. 452-470.

Fry, J. G., Bottjer, D. J., and Lund, S. P., 1985, Magnetostratigraphy of displaced Upper Cretaceous strata in southern California: Geology, v. 13, p. 648-651.

Gaede, V. F., 1957, Leffingwell oil field: California Division of Oil and Gas, Summary of Operations - California Oil Fields, v. 43, n. 2, p. 35-38.

Gastil, G., 1985, Terranes of peninsular California and adjacent Sonora, in Howell, D. G., ed., Tectonostratigraphic terranes of the Circum-Pacific region: Circum-Pacific Council for Energy and Mineral Resources Earth Science Series, No. 1, p. 273-283.

Giraudeau, J., 1992, Distribution of Recent nannofossils beneath the Benguela System, Southwest African continental margin: Marine Geology, v. 108, p. 219-237.

Giraudeau, J., Monteiro, P. M. S., and Nikodemus, K., 1993, Distribution and malformation of living coccolithophores in the northern Benguela upwelling system off Namibia: Marine Micropaleontology, v. 22, p. 93-110.

Grove M., and Bebout, G. E., 1995, Cretaceous tectonic evolution of coastal southern California: insights from the Catalina Schist: Tectonics, v. 14, p. 1290-1308.

Hauksson, E., 1990, Earthquakes, faulting, and stress in the Los Angeles Basin: Journal of Geophysical Research, v. 95 , p. 15365-15394.

Hauksson, E., 1994, The 1991 Sierra Madre earthquake sequence in southern California: seismological and tectonic analysis: Bulletin of the Seismological Society of America, v. 84, p. 1058-1074.

Hauksson, E., and Jones, L. M., 1991, The 1988 and 1990 Upland earthquakes: left-lateral faulting adjacent to the central Transverse Ranges: Journal of Geophysical Research, v. 96, p., 8143-8165.
Hoots, H. W., 1931, Geology of the eastern part of the Santa Monica Mountains, Los Angeles County, California: U. S. Geological Survey Professional Paper 165-C, $134 \mathrm{p}$.

Hornafius, J. S., Luyendyk, B. P., Terres, R. R., and Kamerling, M. J., 1986, Timing and extent of Neogene tectonic rotation in the western Transverse Ranges, California: Geological Society of America Bulletin, v. 97, p. 1476-1487.

Howard, J. L., 2000, Provenance of quartzite clasts in the Eocene-Oligocene Sespe Formation: paleogeographic implications for southern California and the ancestral Colorado River: Geological Society of America Bulletin, v. 112 , p. $1635-1649$.

Howell, D. G., Jones, D. L., and Schermer, E. R., 1985, Tectonostratigraphic terranes of the circum-Pacific region, in Howell, D. G., ed., Tectonostratigraphic terranes of the circum-Pacific region: Circum-Pacific Council for Energy and Mineral Resources, Earth Science Series No. 1, p. 3-30.

Hsü, K. J., 1955, Granulites and mylonites of the region about Cucamonga and San Antonio Canyons, San Gabriel Mountains, California: University of California Geological Sciences Publications, v. 30, p. 223-352.

Hsü, K. J., Edwards, G., and McLaughlin, W. A., 1963, Age of the intrusive rocks of the southeastern San Gabriel Mountains, California: Geological Society of America Bulletin, v. 74, p. 507-512.

Ingersoll, R. V., and Rumelhart, P. E., 1999, Three-stage evolution of the Los Angeles basin, southern California: Geology, v. 27, p. 593-596.

Jacobsen, C. E., 1990, The 40Ar/39Ar geochronology of the Pelona Schist and related rocks, southern California: Journal of Geophysical Research, v. 95, n. B1, p. 509-528.

Jacobsen, C. E., Barth, A. P., Grove, M., 2000, Late Cretaceous protolith age and provenance of the Pelona and Orocopia Schists, southern California: implications for evolution of the Cordilleran margin: Geology, v. 28, p. 219-222.

Jennings, C. W., and Strand, R. G., 1969, Geologic map of California, Los Angeles sheet: California Division of Mines and Geology, scale 1:250,000.

Jones, L. M., Sieh, K. E., Hauksson, E., and Hutton, L. K., 1990, The 3 December 1988 Pasadena, California earthquake: evidence for strike-slip motion on the Raymond fault: Bulletin of the Seismological Society of America, v. 80, p. 474-482.

Joseph, S. E., Criscione, J. J., Davis, T. E., and Ehlig, P. L., 1982, The Lowe igneous pluton, in Fife, D. L., and Minch, J. A., eds., Geology and mineral wealth of the California Transverse Ranges: Santa Ana, California, South Coast Geological Society, Inc., Annual Symposium and Guidebook, Number 10, p. 307-309.

Kling, S. A., 1975, A lagoonal coccolithophore flora from Belize (British Honduras): Micropaleontology, v. 21, p. 1-13.

Lamar, D. L., 1970, Geology of the Elysian Park-Repetto Hills area, Los Angeles County, California: California Division 
of Mines and Geology Special Report 101, 45 p.

Langenheim, V. E., and Jachens, R. C., 1996, Gravity data collected along the Los Angeles Regional Seismic Experiment (LARSE) and preliminary model of regional density variations in basement rocks, southern California: U. S. Geological Survey Open-File Report 96-682, $15 \mathrm{p}$.

Levi, S., and Yeats, R. S., 1993, Paleomagnetic constraints on the initiation of uplift on the Santa Susana fault, western Transverse Ranges, California: Tectonics, v. 12, p. 688-702.

Liddicoat, J. C., 1990, Tectonic rotation of the Santa Ynez Range, California, recorded in the Sespe Formation: Geophysical Journal International, v. 102, p. 739-745.

Liddicoat, J. C., 1992, Palaeomagnetism of the Pico Formation, Santa Paula Creek, Ventura basin, California: Geophysical Journal International, v. 109, p. 1-9.

Lucas, S. G., Whistler, D. P., and Wagner, H. M., 1997, Giant Entelodont (Mammalia Artiodactyla) from the Early Miocene of southern California: Natural History Museum of Los Angeles County, Contributions in Science, n. 466, p. 1-9.

Luyendyk, B. P., 1990, Neogene-age slip in the continental transform zone in southern California: Annales Tectonicae, Special Issue, v. IV, p. 24-34.

Matti, J. C., and Morton, D. M., 1993, Paleogeographic evolution of the San Andreas fault in southern California: in Powell, R. E., Weldon, R. J., II, and Matti, J. C., eds., The San Andreas fault system: displacement, palinspastic reconstruction, and geologic evolution: Geological Society of America Memoir 178, p. 107-159.

May, D. J., and Walker, N. W., 1989, Late Cretaceous juxtaposition of metamorphic terranes in the southeastern San Gabriel Mountains, California: Geological Society of America Bulletin, v. 101, p. 1246-1267.

May, S. R., Ehman, K. D., Gray, G. G., and Crowell, J. C., 1993, A new angle on the tectonic evolution of the Ridge basin, a "strike-slip" basin in southern California: Geological Society of America Bulletin, v. 105, p. 1357-1372.

McCulloh, T. H., 1957, Simple Bouguer anomalies and generalized geologic map of the northwestern part of the Los Angeles basin, California: U. S. Geological Survey Geophysical Investigations Map GP 149, scale $1: 48,000$.

McCulloh, T. H., 1960, Gravity variations and the geology of the Los Angeles Basin of California, in Geological Survey Research 1960: U. S. Geological Survey Professional Paper 400-B, p. 320-325.

McCulloh, T. H., Beyer, L. A., and Enrico, R. J., 2000, Paleogene strata of the eastern Los Angeles basin, California: paleogeography and constraints on Neogene structural evolution: Geological Society of America Bulletin, v. 112, p. 1155-1178.

McIntyre, A., Be, A. W. H., and Roche, M. B., 1970, Modern Pacific Coccolithophorida; a paleontological thermometer: New York Academy of Sciences Transactions, v. 32, p. 720-731.

McMurdie, D. S., Taylor, J. C., and Truex, J. N., compilers, 1973,
Contours on top Miocene, southern Los Angeles basin, in Metropolitan oil fields and their environmental impact: Pacific Sections, American Association of Petroleum Geologists - Society of Exploration Geophysicists Society of Economic Paleontologists and Mineralogists, Guidebook Trip 2, approximate scale 1:111,600.

Miller, F. K., and Morton, D. M., 1977, Comparison of granitic intrusions in the Pelona and Orocopia Schists, southern California: U. S. Geological Survey Journal of Research, v. 5, p. 643-649.

Miller, F. K., and Morton, D. M., 1980, Potassium-argon geochronology of the eastern Transverse Ranges and southern Mojave Desert, southern California: U. S. Geological Survey Professional Paper 1152, 30 p.

Morton, D. M.. 1973, Geology of parts of the Azusa and Mount Wilson Quadrangles, San Gabriel Mountains, Los Angeles County, California: California Division of Mines and Geology Special Report 105, 21 p.

Morton, D. M., 1975, Synopsis of the geology of the eastern San Gabriel Moutains, southern California, in Crowell, J. C., ed., San Andreas fault in southern California: California Division of Mines and Geology Special Report 118, p. 170-176.

Morton, D. M., and Baird, A. K., 1975, Tectonic setting of the San Gabriel Mountains: California Division of Mines and Geology Bulletin 196, p. 3-6.

Morton, D. M., and Matti, J. C., 1987, The Cucamonga fault zone: geologic setting and Quaternary history, in Recent reverse faulting in the Transverse Ranges, California: U. S. Geological Survey Professional Paper 1339, p. 179-203.

Morton, D. M., and Matti, J. C., 1993, Extension and contraction within an evolving divergent strike-slip fault complex: the San Andreas and San Jacinto fault zones at their convergence in southern California, in Powell, R. E., Weldon, R. J., II, and Matti, J. C., eds., The San Andreas fault system: displacement, palinspastic reconstruction, and geologic evolution: Geological Society of America Memoir 178, p. 217-230.

Murray, J. W., 1973, Distribution and ecology of living benthic foraminiferids: New York, Crane, Russek and Company, Inc., 274 p.

Nagle, H. E., and Parker, E. S., 1971, Future oil and gas potential of onshore Ventura basin, California, in Cram, I. H., ed., Future petroleum provinces of the United States - their geology and potential: American Association of Petroleum Geologists Memoir 15, p. 254-297.

Neuerburg, G. J., 1953, Geology of the Griffith Park area, Los Angeles County, California: California Division of Mines and Geology Special Report 33, 29 p.

Nicholson, C., Sorlien, C. C., Atwater, T., Crowell J. C., and Luyendyk, B. P., 1994, Microplate capture, rotation of the western Transverse Ranges, and initiation of the San Andreas transform as a low-angle fault system: Geology, v. 22, p. 491-495.

Nourse, J. A., Weigand, P. W., and Hazelton, G. B., 1998, Igneous and tectonic response of the eastern San Gabriel Mountains to Neogene extension and rotation of the 
Transverse Ranges block, in Behl, R. J., ed., Guidebook to field trip No. 10, 94th Annual Meeting, Cordilleran Section of the Geological Society of America, p. 1-15.

Oakshott, G. B., 1958, Geology and mineral deposits of San Fernando quadrangle, Los Angeles County, California: California Division of Mines and Geology Bulletin 172, San Francisco, 147 p.

Olmsted, F. H., 1950, Geology and oil prospects of western San Jose Hills, Los Angeles County, California: California Journal of Mines and Geology, v. 46, n. 2, p. 191-212.

Oskin, M., Sieh, K., Rockwell, T., Miller, G., Guptill, P., Curtis, M., McArdle, S., and Elliot, P., 2000, Active parasitic folds on the Elysian Park anticline: implications for seismic hazard in central Los Angeles, California: Geological Society of America Bulletin, v. 112, p. 693-707.

Pierce, R. L., 1956, Upper Miocene Foraminifera and fish from the Los Angeles area, California: Journal of Paleontology, v. 30, p. 1288-1314.

Powell, R. E., 1993, Balanced palinspastic reconstruction of pre-late Cenozoic paleogeography, southern California: Geologic and kinematic constraints on evolution of the San Andreas fault system, in Powell, R. E., Weldon, R. J., II, and Matti, J. C., eds., The San Andreas fault system: displacement, palinspastic reconstruction, and geologic evolution: Geological Society of America Memoir 178, p. 1-106.

Powell, R. E., and Weldon, R. J., II, 1992, Evolution of the San Andreas fault: Annual Review Earth and Planetary Sciences, v. 20, p. 431-468.

Proctor, R. J., Payne, C. M., and Kalin, D. C., 1970, Crossing the Sierra Madre fault zone in the Glendora tunnel, San Gabriel Mountains, California: Engineering Geology, v. 4, p. 5-63.

Real, C. R., 1987, Seismicity and tectonics of the Santa MonicaHollywood-Raymond Hill fault zone and northern Los Angeles basin, in Recent reverse faulting in the Transverse Ranges, California: U. S. Geological Survey Professional Paper 1339, p. 113-124.

Redin, T., 1991, Oil and gas production from submarine fans of the Los Angeles basin, in Biddle, K. T., ed., Active margin basins: American Association of Petroleum Geologists Memoir 52, p. 239-259.

Roth, P. H., and Coulbourn, W. T., 1982, Floral and solution patterns of coccoliths in the surface sediments of the North Pacific: Marine Micropalontology, v. 7, p. 1-52.

Rubin, C. M., Lindvall, S. C., and Rockwell, T. K., 1998, Evidence for large earthquakes in metropolitan Los Angeles: Science, v. 281, p. 398-402.

Sage, O., Jr., 1973, Paleocene geography of the Los Angeles region, in Kovach, R. L., and Nur, A., eds., Proceedings of the conference on tectonic problems of the San Andreas fault system: Stanford University Publications in Geological Sciences, v. 13, p. 348-357.

Sage, O., Jr., 1975, Upper Cretaceous and Paleocene sedimentation and tectonic implications, Simi Hills, Ventura County, California, in Weaver, D. W., Hornaday, G. R., and Tipton, A., eds., Paleogene Symposium and selected technical papers: Pacific Sections, American Association of Petroleum Geologists, Society of Paleontologists and Mineralogists, Society of Exploration Geophysicists, Annual Meeting, Conference on Future Energy Horizons of the Pacific Coast, p. 417-438.

Samtleben, C., Schaefer, P., Andruleit, H., Baumann, A., Baumann, K. H., Kohly, A., Mattheissen, J., and Schroeder, R. A., 1995, Plankton in the NorwegianGreenland Sea; from living communities to sediment assemblages - an actualistic approach: Geologische Rundschau, v. 84, p. 108-136.

Schneider, C. L., Hammon, C., Yeats, R. F., and Huftile, G. L., 1996, Structural evolution of the northern Los Angeles basin, California, based on growth strata: Tectonics, v. 15, p. $341-355$.

Schoellhamer, J. E., and Woodford, A. O., 1951, The floor of the Los Angeles basin, Los Angeles, Orange, and San Bernardino Counties, California: U. S. Geological Survey Oil and Gas Investigations Map OM-117.

Schoellhamer, J. E., Vedder, J. G., Yerkes, R. F., and Kinney, D. M., 1981, Geology of the northern Santa Ana Mountains, California: U. S. Geological Survey Professional Paper 420-D, 109 p.

Schwartz, D. E., and Colburn, I. P., 1987, Late Tertiary to Recent chronology of the Los Angeles basin, southern California, in Fischer, P. J., ed., Geology of the Palos Verdes Peninsula and San Pedro Bay: Pacific Section, Society of Economic Paleontologists and Mineralogists and American Association of Petroleum Geologists, Part I, p. 5-16.

Scotti, O., and Nur, A., 1990, 3D block rotation applied to the West Transverse Ranges, California: Annales Tectonicae, v. IV, p. 7-23.

Shaw, J. H., and Shearer, P. M., 1999, An elusive blind-thrust fault beneath metropolitan Los Angeles: Science, v. 283, p. 1516-1518.

Shelton, J. S., 1955, Glendora volcanic rocks, Los Angeles basin, California: Geological Society of America Bulletin, v. 66, p. 45-90.

Silver, L. T., 1971, Problems of crystalline rocks of the Transverse Ranges: Geological Society of America, Abstracts with Programs, v. 3, n. 2, p. 193-194.

Silver, L. T., and Chappell, L. T., 1988, The Peninsular Ranges batholith: an insight into the evolution of the Cordilleran batholiths of southwestern North America: Transactions of the Royal Society of Edinburgh: Earth Sciences, v. 79, p. 105-121.

Smith, D. P., 1986, Geology of the north half of the Pasadena quadrangle, Los Angeles County, California: California Division of Mines and Geology Open-File Report 86-4, $40 \mathrm{p}$.

Sorensen, S. S., 1985, Petrologic evidence for Jurassic islandarc-like basement rocks in the southwestern Transverse Ranges and California continental borderland: Geological Society of America Bulletin, v. 96, p. 997-1006.

Sorensen, S., 1988, Tectonometamorphic significance of the basement rocks of the Los Angeles basin and the inner California Continental Borderland, in Ernst, W. G., ed., 
Metamorphism and crustal evolution of the western United States (Rubey Volume 7): Englewood Cliffs, New Jersey, Prentice Hall, p. 998-1022.

Sullwold, H. H., Jr., 1960, Tarzana fan, deep submarine fan of late Miocene age, Los Angeles, County, California: American Association of Petroleum Geologists Bulletin, v. 44, p. 433-457.

Taylor, H. P., and Silver, L. T., 1978, Oxygen isotope relationships in plutonic igneous rocks of the Peninsular Ranges batholith, southern and Baja California, in Zartman, R. E., ed., Short papers of the Fourth International Conference, Geochronology, Cosmochronology, Isotope Geology: U. S. Geological Survey Open-File Report 78-701, p. 423-426.

Truex, J. N., 1976, Santa Monica and Santa Ana Mountains - relation to Oligocene Santa Barbara basin: American Association of Petroleum Geologists Bulletin, v. 60, p. 65-86.

Weber, F. H., Jr., Bennett, J. H., Chapman, R. H., Chase, G. W., and Saul, R. B., 1980, Earthquake hazards associated with the Verdugo-Eagle Rock and Benedict Canyon fault zones, Los Angeles County, California: California Division of Mines and Geology, Open-File Report 80-10 LA, $165 \mathrm{p}$.

West, J. C., and Redin, T. W., 1991, Correlation section across eastern Los Angeles basin from San Pedro Bay to San Gabriel Mts.: Pacific Section, American Association of Petroleum Geologists, scale 1:48,000 (horizontal), 1:12,000 (vertical).

Winter, A., 1985, Distribution of living coccolithophores in the California Current system, southern California Borderland: Marine Micropaleontology, v. 9, p. 385-393.

Woodburne, M O., 1975, Cenozoic stratigraphy of the Transverse Ranges and adjacent areas, southern California: Geological Society of America Special Paper 162, 91 p.

Woodford, A. O., Shelton, J. S., and Moran, T. G., 1945, Geology and oil possibilities of Puente and San Jose Hills, California, 1944: U. S. Geological Survey Oil and Gas Investigation, Preliminary Map 23, scale approximately $1: 63,360$.

Woodford, A. O., Moran, T. G., and Shelton, J. S., 1946, Miocene conglomerates of Puente and San Jose Hills, California: American Association of Petroleum Geologists Bulletin, v. 30, p. 514-560.

Wright, T., 1987, Geologic summary of the Los Angeles basin, in Wright, T., and Heck, R., eds., Petroleum geology of coastal southern California: Pacific Section, American Association of Petroleum Geologists Guidebook 60, p. 21-31.

Wright, T. L., 1991, Structural geology and tectonic evolution of the Los Angeles basin, California, in Biddle, K. T., ed., Active margin basins: American Association of Petroleum Geologists Memoir 52, p. 35-134.

Yeats, R. S., 1968, Southern California structure, sea-floor speading, and history of the Pacific basin: Geological Society of America Bulletin, v. 79, p. 1693-1702.

Yeats, R. S., 1973, Newport-Inglewood fault zone, Los Angeles basin, California: American Association of Petroleum Geologists Bulletin, v. 57, p. 117-135.

Yeats, R. S., 1976, Extension versus strike-slip origin of the Southern California Borderland, in Howell, D. G., ed., Aspects of the geologic history of the California Continental Borderland: Pacific Section, American Association of Petroleum Geologists Miscellaneous Publication 24, p. 455-485.

Yeats, R. S., 1987, Late Cenozoic structure of the Santa Susana fault zone, in Recent reverse faulting in the Transverse Ranges, California, in Recent reverse faulting in the Transverse Ranges, California: U. S. Geological Survey Professional Paper 1339, p. 137-160.

Yeats, R. S., Huftile, G. J., and Stitt, L. T., 1994, Late Cenozoic tectonics of the east Ventura basin, Transverse Ranges, California: American Association of Petroleum Geologists Bulletin, v. 78, p. 1040-1074.

Yerkes, R. F., 1972, Geology and oil resources of the western Puente Hills area, southern California: U. S. Geological Survey Professional Paper 420-C, 63 p.

Yerkes, R. F., and Campbell, R. H., 1971, Cenozoic evolution of the Santa Monica Mountains-Los Angeles basin area: I. Constraints on tectonic models [abs.]: Geological Society of America, Abstracts with Programs, v. 3, n. 2, p. 222-223.

Yerkes, R. F., and Campbell, R. H., 1979, Stratigraphic nomenclature of the central Santa Monica Mountains, Los Angeles County, California: U. S. Geological Survey Bulletin 1457-E, p. E1-E31.

Yerkes, R. F., McCulloh, T. H., Schoellhamer, J. E., and Vedder, J. G., 1965, Geology of the Los Angeles basin an introduction: U. S. Geological Survey Professional Paper 420-A, 57 p.

Young, J. R., 1998, Neogene, in Bown, P. R., ed., Calcareous nannofossil biostratigraphy: London, Chapman and Hall, p. 225-265.

Ziveri, P., Thunell, R. C., and Rio, D., 1995, Export production of coccolithophores in an upwelling region: results from San Pedro basin, southern California borderlands: Marine Micropaleontology, v. 24, p. 335-358. 


\section{APPENDIX 1}

Petroleum exploration drill holes that furnish information about the presence or absence of Sespe or pre-Sespe sedimentary rocks (fig. 5), the nature and configuration of pre-sedimentary basement rocks (fig. 2), and distribution of sedimentary and volcanic rocks of the Topanga Group (fig. 6).

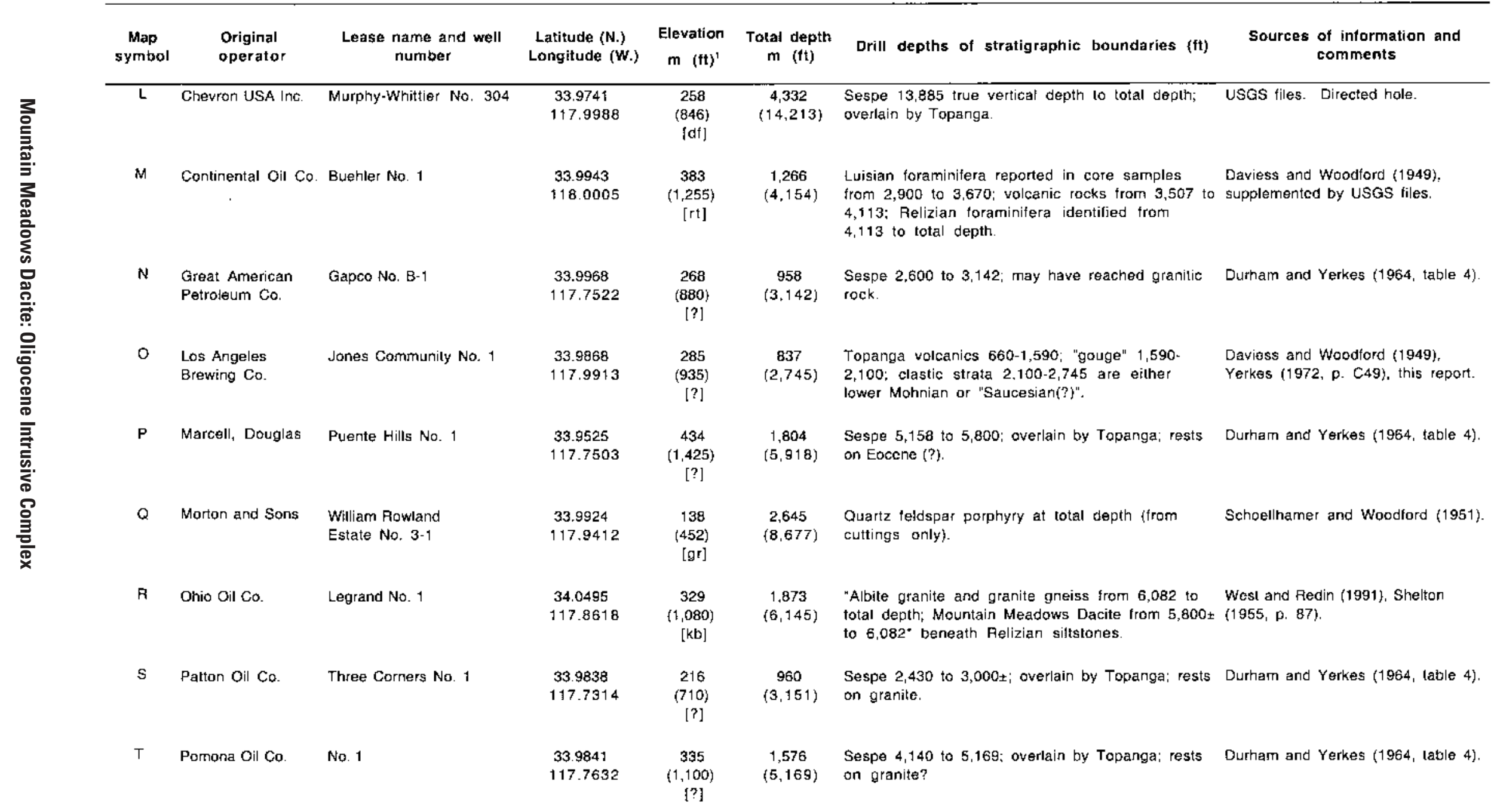




\section{APPENDIX 1-Continued}

$u$

Shell Oil Co.

Puente Corehole No. 4

33.9930
117.7541

269

(884)

930

$(3,052)$

Sespe 2,300 to 2,934 ; overlain by Topanga; rests

on granodiorite of Peninsular Ranges aspect.

Durham ano Yerkes (1964, table 4),

v Shell Oil Co

Menchego No. $\theta$ (directed hole)

33.9463

117.8658

W Shell Oit Co

Puente No. A-3

33.9551

117.9052

238
$(780)$

[df]

2,745

$(9,007)$

Schistose metavolcanic rocks trom 6,130 to total depth; overlain by Topanga sedimentary rocks.

Y Standard Oil Co.

Puente No. A-6

33.9569

117.9042

317

$(1,040)$

Woodward Community $\quad 33.9223$ No. K-1

118.0011

75

(245)

33.9555

117.7298

291

(955)

34.0387

117.8918

346
$\{1,136\}$

$\begin{array}{lr}33.9203 & 354 \\ 117.6730 & (1.160) \\ & {[d f]}\end{array}$

Tidewater

Abacherli No. 1

Sansinena No. 8-B-2

33.9583

117.940

265
$(870)$

California

Union-Signal-Texam $U$.

34.0424

118.3097

62

California

19 No. 1

33.968

33.9698
117.8311

Diamond Bar No.

Oil Co.
1,588 Schistose meta-andesite trom 4,710 10 total

$(5,211)$ depth; overłain by Topanga sedimentary rocks.

1.678 "Albite and oligoclase-epidote amphibolites"

$(5,506)$ (Sorensen, 1985, p. 999) overlain unconformably by basal Mohnian of Modelo Fm.

1,527
$(\mathbf{5}, \mathbf{0 1 0})$

Schistose meta-andesite from 4,457 to total depth; a composite sample analyzed by $R$. W Kistler yielded ${ }^{57} \mathrm{Sr}^{85} \mathrm{Sr}$ (measured) $=0.70422$, giving an initial ralio of 0.7041 ; overlain by Topanga sedimentary rocks.

1,408

$(4,618)$

Schistose meta-andesite from 4,448 to lotal

depth; overlain by Topanga sedimentary rocks.

3,714 Sespe 11,965 to tolal depth.

$(12,184)$

1,59

$\{5.231\}$

Sespe 3,835 to 4,400 ; overlain by Topanga; rests

on Eocene.

2,179

(7.148)

Quartz diorite grading to protomylonite was cored trom 6,838 to total depth; overlain by Topanga or Glendora (Relizian) Volcanics at $6,780 \pm$

1,517 Sespe 3,820 to 4,210; overlain by Topanga; rests

$(4,977)$ on Eocene

Schoellhamer and Woodford (1951). Yerkes $(1972$, p. C5, table 6) Kisller (written comm., 1980).

Yerkes $(1972$, table 6$)$

Yerkes (1972, table 6).

Durham and Yerkes (1964, table 4). McCulloh and others (2000).

Schoellhamer and Woodford (1951\}. $\{1991$

Durnam and Yerkes (1964), Castro (1975). MeCulloh and others $(2000)$.

Yerkes (1972, Table 6).

Yeats (1973, p. 134)

Schneider and others (1996, Fig. 5).

2,081 Sespe 5.700 \pm to total depth; overlain by Topanga. Durham and Yerkes (1964, table 4)

$\begin{array}{rr}117.8311 & \$ 1,102 \\ {[?]} & \end{array}$




\section{APPENDIX 2}

Calcareous nannofossils identified in key outcrop and drill hole samples in the northernmost part of the Los Angeles Basin that help provide understanding of the Middle Miocene stratigraphy and paleoceanography.

\begin{tabular}{|c|c|c|c|c|c|c|c|c|c|c|c|c|c|c|c|c|c|c|c|c|}
\hline \multirow[t]{2}{*}{ Taxa } & \multicolumn{5}{|c|}{ CN zones } & \multicolumn{15}{|c|}{$\begin{array}{l}\text { Nannofossll count (VR = very rare) } \\
\text { Sample locations 1-15 foolnates) }\end{array}$} \\
\hline & $5 b$ & $5 a$ & 4 & 3 & 2 & 1 & 2 & 3 & 4 & 5 & 6 & 7 & 8 & $g$ & 10 & 11 & 12 & 13 & 14 & 15 \\
\hline Braarudosphaera bigelowii & & & & & & VF & VR & & & VR & & VR & & VR & & VR & VF & VR & VP & \\
\hline Calcidiscus feptoporus & & & & & & & VR & & & VR & & 1 & & & & & VA & & & VR \\
\hline Calcidiscuss praemactntyrei & & $x$ & $x$ & $x$ & & VA & VR & VR & WA & 1 & VR & VA & & & & & & & $V R$ & VF \\
\hline Coccolithus miopelagicus & $x$ & $x$ & $x$ & $x$ & $x$ & VP & 1 & & & VR & & & 1 & 3 & 18 & & & & 1 & \\
\hline Coccolithus petagicus & & & & & & 376 & 132 & 157 & 17 & 153 & 33 & 26 & 7 & 20 & 31 & 164 & 148 & 116 & 68 & 26 \\
\hline ?Coronocyctus sp. cf. C. nifescens & & $?$ & $x$ & $x$ & $x$ & & & & & & & & & & & & & & & VA \\
\hline Cyclicargolithus floridanus & & $x$ & $x$ & $x$ & $x$ & VA & 1 & VR & VA & 1 & 1 & VA & 1 & & 1 & 1 & 1 & 3 & VR & 1 \\
\hline Dictyococcifes antarcticus & & & & & & 8 & 15 & 30 & 14 & 21 & 64 & 32 & 61 & 39 & 7 & & 30 & 40 & 230 & 16 \\
\hline Dictyocaccites productus & & & & & & 64 & 460 & 1920 & 261 & 283 & 258 & 293 & 736 & 80 & 9 & 55 & 1840 & 1112 & 230 & 252 \\
\hline Discoaster deffandret & $x$ & $x$ & $x$ & $x$ & $x$ & & 1 & & VP & VR & & VA & & & & & VR & VR & & VA \\
\hline Discoaster musicus & & & & & & & & & 1 & VR & & & & & VR & & & & & VA \\
\hline Discoaster spp. & & & & & & & VR & & VF & & & & & 1 & 1 & & VA & & VF & 1 \\
\hline Discoaster subsurcutus & & & & & & & & & & vR & & & & & & & & & & \\
\hline Eiffelfithus eximius (reworked) & & & & & & VA & & & & & & & & & & & & & & \\
\hline Heticosphaera amotiaperta & & & & $x$ & $x$ & & & & & & & & & & & & & & VR & \\
\hline Heticosphaera sp. cf. H. ampltaperta & & & & & & & & VR & & & & & & & VR & & & & & \\
\hline Heticosphaera canteri & & & & & & VA & VA & 1 & VR & VA & VA & 3 & & & 1 & 2 & 2 & 1 & VR & VA \\
\hline Helicosphaera euphratis & & & & & & & & & VR & vR & & & & & & & & & & \\
\hline Heticosphaera granulata & & & & & & & & VR & & & & & & & & & & & & \\
\hline Helicosphacra intermedia & & & & & & & & & & & & VR & & & & & & & & \\
\hline Helicosphaera minuta & & & & & & 2 & & & & & & & & & & & & & & \\
\hline Hetiolithus sp. (reworked) & & & & & & $\mathrm{VH}$ & & & & & & & & & & & & & & \\
\hline Lithostromation perourum & & & & & & & & & & & & & 1 & & & & VR & & & \\
\hline Microrantholithus fios & & & & & & & & & & & & & & & & & VR & & & \\
\hline Neochisatozygus (reworked) & & & & & & & & & & & & & & & & & & & & VA \\
\hline Pontosphaera multipora & & & & & & & & & & & & & & & & & VR & & & \\
\hline Radiolithus planus (reworked) & & & & & & & & & & & & & & & & & VR & & & \\
\hline Reticutofenestra lockeri & & & & $x$ & $x$ & & & & & & & & & & & & & & VR & 5 \\
\hline Reticufofenestra minututa & & & & & & 4 & 6 & 3 & 1 & 2 & 4 & 3 & VR & 6 & 7 & 1 & 3 & VA & 146 & 1 \\
\hline Reticutofenestra pseudoumbificus $\{5-7,4 \mathrm{~m}\}$ & $\mathrm{x}$ & $\mathrm{x}$ & $x$ & $x$ & & & 71 & 57 & 13 & & 21 & 25 & 16 & 47 & 21 & & 9 & 7 & 704 & 9 \\
\hline Reticulofenestra psevdoumbifficus $(>7 \mu \mathrm{m})$ & $x$ & $x$ & & & & & 11 & 4 & 2 & & 4 & 4 & 7 & 6 & 4 & & VR & & 2 & 2 \\
\hline Sphenolithus compactus & & & & & & & VA & VR & VR & 2 & & & $V R$ & & & & VR & VA & VR & \\
\hline Sphenotithus heteromorphus & & & $x$ & $x$ & & 1 & & & & & & & & & & & 1 & & & \\
\hline Sphenolithus sp. cf. S. heteromorphus & & & & & & & & & & & & & VR & & & & & & & \\
\hline Sphenotithus spp. & & & & & & VR & & VA & & 1 & 3 & 1 & 3 & 1 & VR & VH & 2 & & VR & 1 \\
\hline Triorbis sp. & & & & & & VR & & VR & & 1 & VF & & & & & 2 & 4 & VA & VR & \\
\hline Watznauena bamesae (reworked) & & & & & & & 1 & VR & & & & & & Vम & & 1 & VR & & VR & \\
\hline Walznaveria bigorta (reworked) & & & & & & & & & & & & & & & & & VR & & & \\
\hline Individuals counted & & & & & & 455 & 699 & 2172 & 309 & 465 & 388 & 388 & 833 & 203 & 100 & 225 & 2040 & 1279 & 1381 & $\$ 14$ \\
\hline Species counted & & & & & & 6 & 8 & 6 & 6 & 9 & 7 & 8 & 8 & 8 & 9 & 6 & 9 & 6 & 6 & 9 \\
\hline CN zone(s) represented & & & & & & $3-4$ & $3-5 a$ & $3-5 a$ & $3-5 a$ & $3-5 a$ & $3-5 a$ & $3 \cdot 5 a$ & $3 \cdot 4 ?$ & $3.5 b$ & $3.5 a$ & $1.5 a$ & 3.4 & $9-5 b$ & 3 & 3 \\
\hline Fisher alpha index & & & & & & 1.0 & 1.3 & 0.8 & 1.1 & 1.6 & 1.2 & 1.4 & 1.2 & 1.7 & 2.4 & 12 & 1.2 & 08 & 0.8 & 17 \\
\hline Locality $\alpha$, ligure $6,34.1182 \mathrm{~N}, 118.2113^{\circ} \mathrm{W}$ & & & & & & & "Drill & hole $\mathrm{C}$ & O, App & pendix & $<1$ and & figure & 6, sa & ample & depth & $2225 \dagger$ & & & & \\
\hline${ }^{2}$ Locality $\beta$, figure 6, $34.1327^{\circ} \mathrm{N}, 117.7961^{\prime \prime} \mathrm{W}$ & & & & & & & ${ }^{10}$ Dril & I hole & O. Apr & pendix & $x 1$ and & d figur & 6.5 & ample & depth & 2745 & $\mathrm{ft} . ?$ & & & \\
\hline "Locality $\beta$, figure 6, 34.1327" N. $117.7961^{\circ} \mathrm{W}$ & & & & & & & "Dril & I hole. & J, tabl & e 4 an & nd figur & re $6, s$ & sample & depth & h 8695 & $5-97 \mathrm{ft}$ & & & & \\
\hline${ }^{2}$ Orill hole $\mathrm{V}$. lable 2 and figure 6 , sample dep & 552 & 0.48 & & & & & ${ }^{12}$ Dril & I hole | & lili, tab & le 2 a & Ind fige & ure 6. & sampl & e depl & In 107 & $1-108$ & $11 \mathrm{ft}$. & & & \\
\hline "Orill hole IV, lable 2 and figure 6 , sample dep & 594 & $6 \cdot 66$ & & & & & ${ }^{3}$ Drill & I hole I & $|+|, t a b \mid$ & le 2 ar & nd ligu & dre 6. & sampl & e deptr & an 1091 & $1-1101$ & $1 \mathrm{Ht}$ & & & \\
\hline 'Drill hole IV, lable 2 and figure 6 , sample dep & 604 & & & & & & ${ }^{14}$ Drill & | hole I & $|\mathrm{I}|$ tabl & le 2 ar & nd ligu & ure 6, & sampl & $\theta$ deptl & th 1760 & $0-70 \mathrm{ft}$ & & & & \\
\hline 'Drill hole IV, rable 2 and figure 6 , sample dep & 612 & & & & & & ${ }^{15}$ Drill & hole 0 & Q, app & yendix & 1 and & ligure & e 6 , sa & ample c & depth & $8150-\xi$ & $-80 \mathrm{tt}$ & & & \\
\hline Drill hole $M$, appendix $\uparrow$ and figure 6 , samp & & & & & & & & & & & & & & & & & & & & \\
\hline
\end{tabular}

